\title{
Total Petroleum Systems of the Illizi Province, Algeria and Libya-Tanezzuft-Illizi
}

By T.R. Klett

U.S. Geological Survey Bulletin 2202-A

U.S. Department of the Interior

U.S. Geological Survey 


\section{U.S. Department of the Interior \\ Bruce Babbitt, Secretary}

\section{U.S. Geological Survey \\ Charles G. Groat, Director}

This report is only available online at:

http://greenwood.cr.usgs.gov/pub/bulletins/b2202-a/

Any use of trade, product, or firm names in this publication is for descriptive purposes only and does not imply

endorsement by the U.S. Government 


\section{Contents}

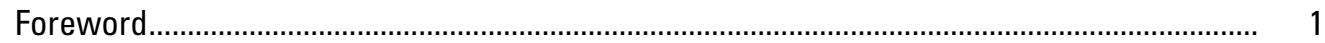

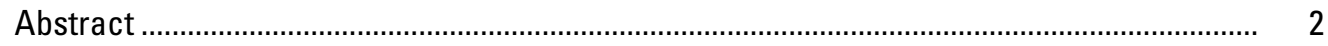

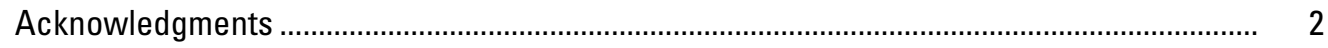

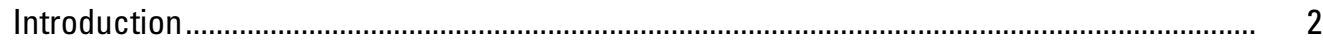

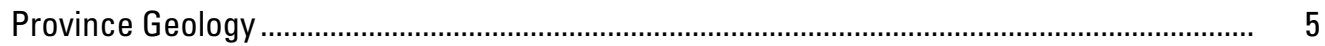

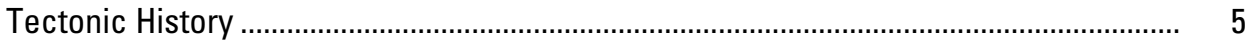

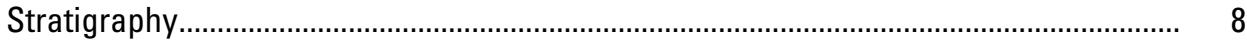

Petroleum Occurrence ................................................................................................. 11

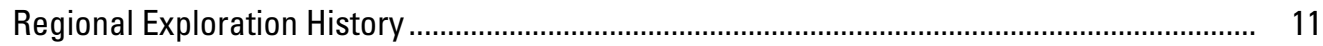

The Tanezzuft-Illizi Total Petroleum System (205601) ............................................................ 11

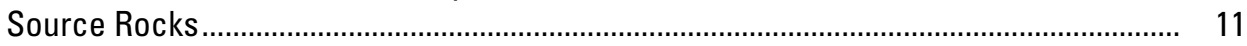

Overburden Rocks................................................................................................. 13

Reservoir Rocks ........................................................................................................... 13

Seal Rocks ................................................................................................................... 13

Trap Types in Oil and Gas Fields.................................................................................... 13

Assessment of Undiscovered Petroleum by Assessment Unit ....................................... 13

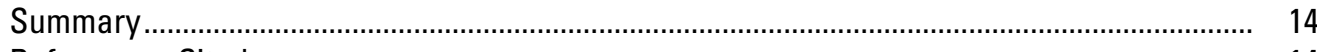

References Cited .............................................................................................................. 14

Appendix. Exploration-activity and discovery-history plots for the Tanezzuft-Illizi

Structural/Stratigraphic Assessment Unit

\section{Figures}

1-3. Map showing approximate locations of:

1. USGS-defined geologic provinces and major structures in northcentral Africa

2. Areal extent of total petroleum systems and Silurian source rocks (Tanezzuft Formation), and locations of stratigraphic cross sections, north-central Africa.

3. Areal extent of assessment units within Illizi Province.

4. Stratigraphic cross sections through Illizi and neighboring provinces

5. Columnar section and stratigraphic nomenclature for Illizi, Triassic, and Ghadames (Berkine) Basins.

6. Tanezzuft-Illizi Total Petroleum System

\section{Tables}

[Tables and Appendix follow References Cited]

1. Abbreviations, names, ages, and lithology of formations used in the total petroleum systems events chart

2. Reservoir properties of accumulations for the Tanezzuft-Illizi Structural/Stratigraphic Assessment Unit through 1995

3. Number and sizes of discovered fields for the Tanezzuft-Illizi Structural/Stratigraphic Assessment Unit through 1995

4. Estimated sizes, number, and coproduct ratios of undiscovered oil and gas fields for the Tanezzuft-Illizi Structural/Stratigraphic Assessment Unit

5. Estimated undiscovered conventional oil, gas, and natural gas liquids volumes for oil and gas fields for the Tanezzuft-Illizi Structural/Stratigraphic Assessment Unit 


\title{
Total Petroleum Systems of the Illizi Province, Algeria and Libya-Tanezzuft-Illizi
}

\author{
By T.R. Klett
}

\section{Foreword}

This report was prepared as part of the U.S. Geological Survey World Petroleum Assessment 2000. The primary objective of World Petroleum Assessment 2000 is to assess the quantities of conventional oil, gas, and natural gas liquids outside the United States that have the potential to be added to reserves in the next 30 years. Parts of these assessed volumes reside in undiscovered fields whose sizes exceed the stated minimumfield-size cutoff value for the assessment unit, which is variable but must be at least 1 million barrels of oil equivalent. Another part of these assessed volumes occurs as reserve growth of fields already discovered. However, the contribution from reserve growth of discovered fields to resources is not covered for the areas treated in this report.

In order to organize, evaluate, and delineate areas to assess, the Assessment Methodology Team of World Petroleum Assessment 2000 developed a hierarchical scheme of geographic and geologic units. This scheme consists of regions, geologic provinces, total petroleum systems, and assessment units. For World Petroleum Assessment 2000, regions serve as organizational units and geologic provinces are used as prioritization tools. Assessment of undiscovered resources was done at the level of the total petroleum system or assessment unit.

The world was divided into 8 regions and 937 geologic provinces. These provinces have been ranked according to the discovered known oil and gas volumes (Klett and others, 1997). Then, 76 "priority" provinces (exclusive of the United States and chosen for their high ranking) and 26 "boutique" provinces (exclusive of the United States) were selected for appraisal of oil and gas resources. Boutique provinces were chosen for their anticipated petroleum richness or special regional economic or strategic importance.

A geologic province is an area having characteristic dimensions of hundreds of kilometers that encompasses a natural geologic entity (for example, a sedimentary basin, thrust belt, or accreted terrane) or some combination of contiguous geologic entities. Each geologic province is a spatial entity with common geologic attributes. Province boundaries were drawn as logically as possible along natural geologic boundaries, although in some places they were located arbitrarily (for example, along specific water-depth contours in the open oceans).

Total petroleum systems and assessment units were delineated for each geologic province considered for assessment. It is not necessary for the boundaries of total petroleum systems and assessment units to be entirely contained within a geologic province. Particular emphasis is placed on the similarities of petroleum fluids within total petroleum systems, unlike geologic provinces and plays in which similarities of rocks are emphasized.
The total petroleum system includes all genetically related petroleum that occurs in shows and accumulations (discovered and undiscovered) generated by a pod or by closely related pods of mature source rock. Total petroleum systems exist within a limited mappable geologic space, together with the essential mappable geologic elements (source, reservoir, seal, and overburden rocks). These essential geologic elements control the fundamental processes of generation, expulsion, migration, entrapment, and preservation of petroleum within the total petroleum system.

An assessment unit is a mappable part of a total petroleum system in which discovered and undiscovered oil and gas fields constitute a single relatively homogeneous population such that the methodology of resource assessment based on estimation of the number and sizes of undiscovered fields is applicable. A total petroleum system might equate to a single assessment unit. If necessary, a total petroleum system may be subdivided into two or more assessment units such that each assessment unit is sufficiently homogeneous in terms of geology, exploration considerations, and risk to assess individually. Differences in the distributions of accumulation density, trap styles, reservoirs, and exploration concepts within an assessment unit were recognized and not assumed to extend homogeneously across an entire assessment unit.

A numeric code identifies each region, province, total petroleum system, and assessment unit. The criteria for assigning codes are uniform throughout the project and throughout all publications of the project. The numeric codes used in this study are:

Unit Name Code

Region Middle East and North Africa 2 Province Illizi 2056

Total Petroleum System Tanezzuft-Illizi 205601

Assessment Unit Tanezzuft-Illizi Structural/ 20560101 Stratigraphic

A graphical depiction that places the elements of the total petroleum system into the context of geologic time is provided in the form of an events chart. Items on the events chart include (1) the major rock-unit names; (2) the temporal extent of sourcerock deposition, reservoir-rock deposition, seal-rock deposition, overburden-rock deposition, trap formation, generation-migration-accumulation of petroleum, and preservation of petroleum; and (3) the critical moment, which is defined as the time that best depicts the generation-migration-accumulation of hydrocarbons in a petroleum system (Magoon and Dow, 1994). The events chart serves only as a timeline and does not necessarily represent spatial relations.

Probabilities of occurrence of adequate charge, rocks, and timing were assigned to each assessment unit. Additionally, an access probability was assigned for necessary petroleum-related 
activity within the assessment unit. All four probabilities, or risking elements, are similar in application and address the question of whether at least one undiscovered field of minimum size has the potential to be added to reserves in the next 30 years somewhere in the assessment unit. Each risking element thus applies to the entire assessment unit and does not equate to the percentage of the assessment unit that might be unfavorable in terms of charge, rocks, timing, or access.

Estimated total recoverable oil and gas volumes (cumulative production plus remaining reserves, called "known" volumes hereafter) quoted in this report are derived from Petroconsultants, Inc., 1996 Petroleum Exploration and Production database (Petroconsultants, 1996a). To address the fact that increases in reported known volumes through time are commonly observed, the U.S. Geological Survey (Schmoker and Crovelli, 1998) and the Minerals Management Service (Lore and others, 1996) created a set of analytical "growth" functions that are used to estimate future reserve growth (called "grown" volumes hereafter). The set of functions was originally created for geologic regions of the United States, but it is assumed that these regions can serve as analogs for the world. This study applied the Federal offshore Gulf of Mexico growth function (developed by the U.S. Minerals Management Service) to known oil and gas volumes, which in turn were plotted to aid in estimating undiscovered petroleum volumes. These estimates of undiscovered petroleum volumes therefore take into account reserve growth of fields yet to be discovered.

Estimates of the minimum, median, and maximum number, sizes, and coproduct ratios of undiscovered fields were made based on geologic knowledge of the assessment unit, exploration and discovery history, analogs, and, if available, prospect maps. Probabilistic distributions were applied to these estimates and combined by Monte Carlo simulation to calculate undiscovered resources.

Illustrations in this report that show boundaries of the total petroleum systems, assessment units, and extent of source rocks were compiled using geographic information system (GIS) software. The political boundaries shown are not politically definitive and are displayed for general reference only. Oil and gas field center points were provided by, and reproduced with permission from, Petroconsultants (1996a and 1996b).

\section{Abstract}

Undiscovered conventional oil and gas resources were assessed within a total petroleum system of the Illizi Province (2056) as part of the U.S. Geological Survey World Petroleum Assessment 2000. The Illizi Province is in eastern Algeria and a small portion of western Libya. The province and its total petroleum system coincide with the Illizi Basin. Although several total petroleum systems may exist within the Illizi Province, only one "composite" total petroleum system is identified. This total petroleum system comprises a single assessment unit.

The main source rocks are the Silurian Tanezzuft Formation (or lateral equivalents) and Middle to Upper Devonian mudstone. The total petroleum system was named after the oldest major source rock and the basin in which it resides.

The estimated means of the undiscovered conventional petroleum volumes in the Tanezzuft-Illizi Total Petroleum
System are 2,814 million barrels of oil (MMBO), 27,785 billion cubic feet of gas (BCFG), and 873 million barrels of natural gas liquids (MMBNGL).

\section{Acknowledgments}

I thank Philip Farfan and Francois Gauthier of Anadarko Algeria Corporation, Rob Hoar and Randie Grantham of Oryx Energy Company, and David Boote and Marc Traut of Occidental Oil and Gas Corporation for their suggestions, which greatly improved the text. I also thank Katharine Varnes, Gordon Dolton, and Gregory Ulmishek for their editorial review.

\section{Introduction}

Undiscovered conventional oil and gas resources were assessed within a total petroleum system of the Illizi Province (2056) as part of the U.S. Geological Survey (USGS) World Petroleum Assessment 2000. This study documents the geology, undiscovered oil and gas volumes, exploration activity, and discovery history of the Illizi Province.

The Illizi Province is a geologic province delineated by the USGS; it is located in eastern Algeria and extreme western Libya (fig. 1). The province encompasses approximately $200,000 \mathrm{~km}^{2}$ (square kilometers) and coincides with the Illizi Basin. Neighboring geologic provinces, delineated by the USGS, are the Trias/Ghadames Basin (2054), Hamra Basin (2047), Tihemboka Uplift (2057), Hoggar (7041), and Grand Erg/Ahnet Basin (2058).

More than one total petroleum system may exist within the Illizi Basin (Boote and others, 1998). Data available for this study are insufficient to adequately determine the relative contribution of each system to individual accumulations and therefore preclude further subdivision. Consequently only one "composite" total petroleum system is described in this report, which contains all total petroleum systems, called the Tanezzuft-Illizi Total Petroleum System (fig. 2). Tanezzuft refers to the Tanezzuft Formation (Silurian), which is the oldest major source rock in the system; in the total petroleum system name, "Tanezzuft" is then followed by the basin name in which the total petroleum system exists. Due to scarcity of data, province and total petroleum system boundaries can only be approximately delineated and therefore are subject to future modification.

One assessment unit was defined in the Tanezzuft-Illizi Total Petroleum System; the assessment unit coincides with the total petroleum system (fig. 3). The assessment unit is named after the total petroleum system with a suffix of "Structural/ Stratigraphic." This suffix refers to the progression from a structural and combination trap exploration strategy to a stratigraphic (subtle) trap exploration strategy.

The Illizi Province contains more than 4,600 million barrels $(\mathrm{MMB})$ of known (estimated total recoverable, that is, cumulative production plus remaining reserves) petroleum liquids (approximately 3,700 million barrels of oil, MMBO, and 900 million barrels of natural gas liquids, MMBNGL) and approximately 45,000 billion cubic feet of known natural gas (10 9 CFG or BCFG) (Petroconsultants, 1996a). The Illizi 


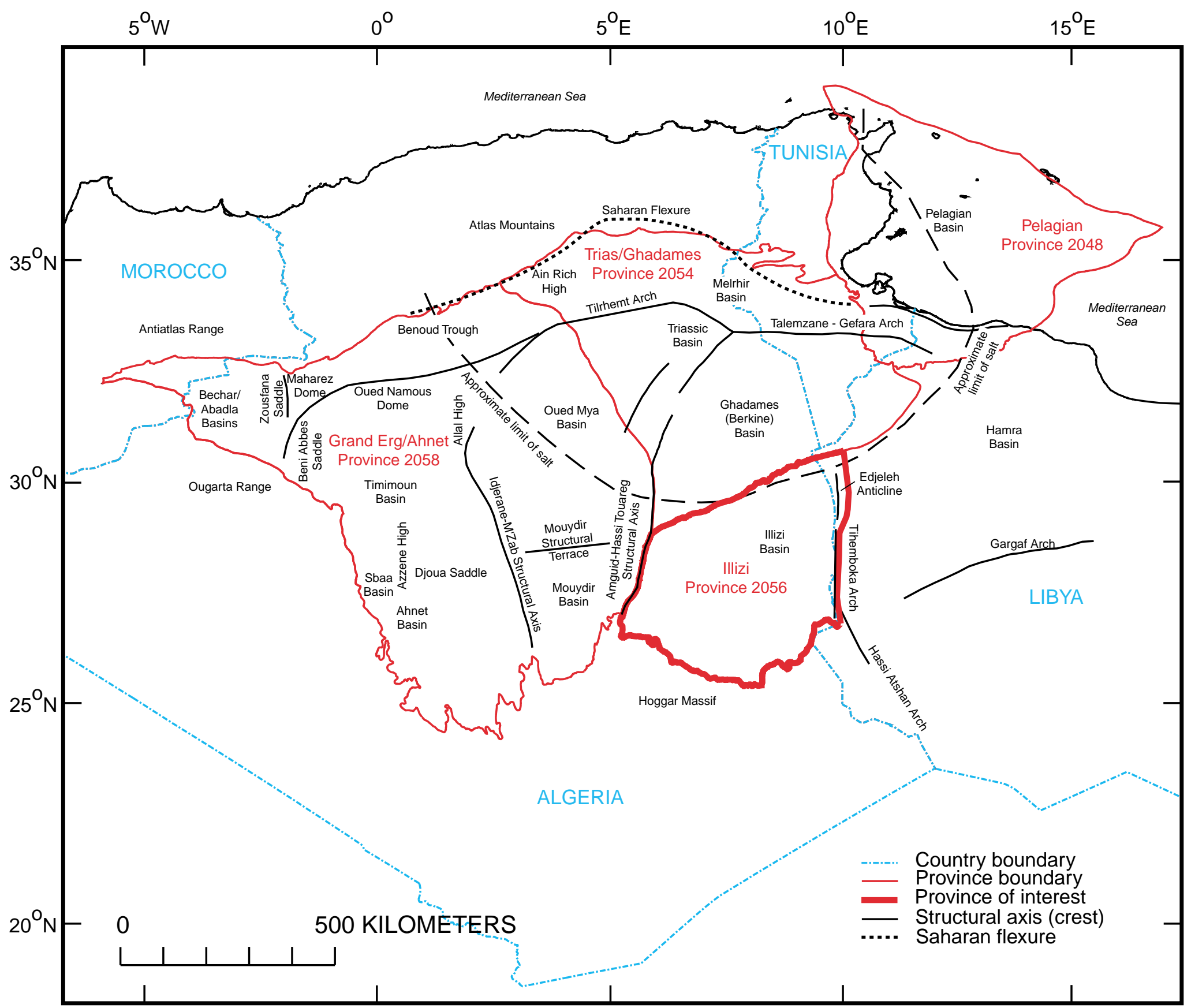

Figure 1. North-central Africa, showing USGS-defined geologic provinces and major structures (modified from Aliev and others, 1971; Burollet and others, 1978; Montgomery, 1994; Petroconsultants, 1996b; Persits and others, 1997). 


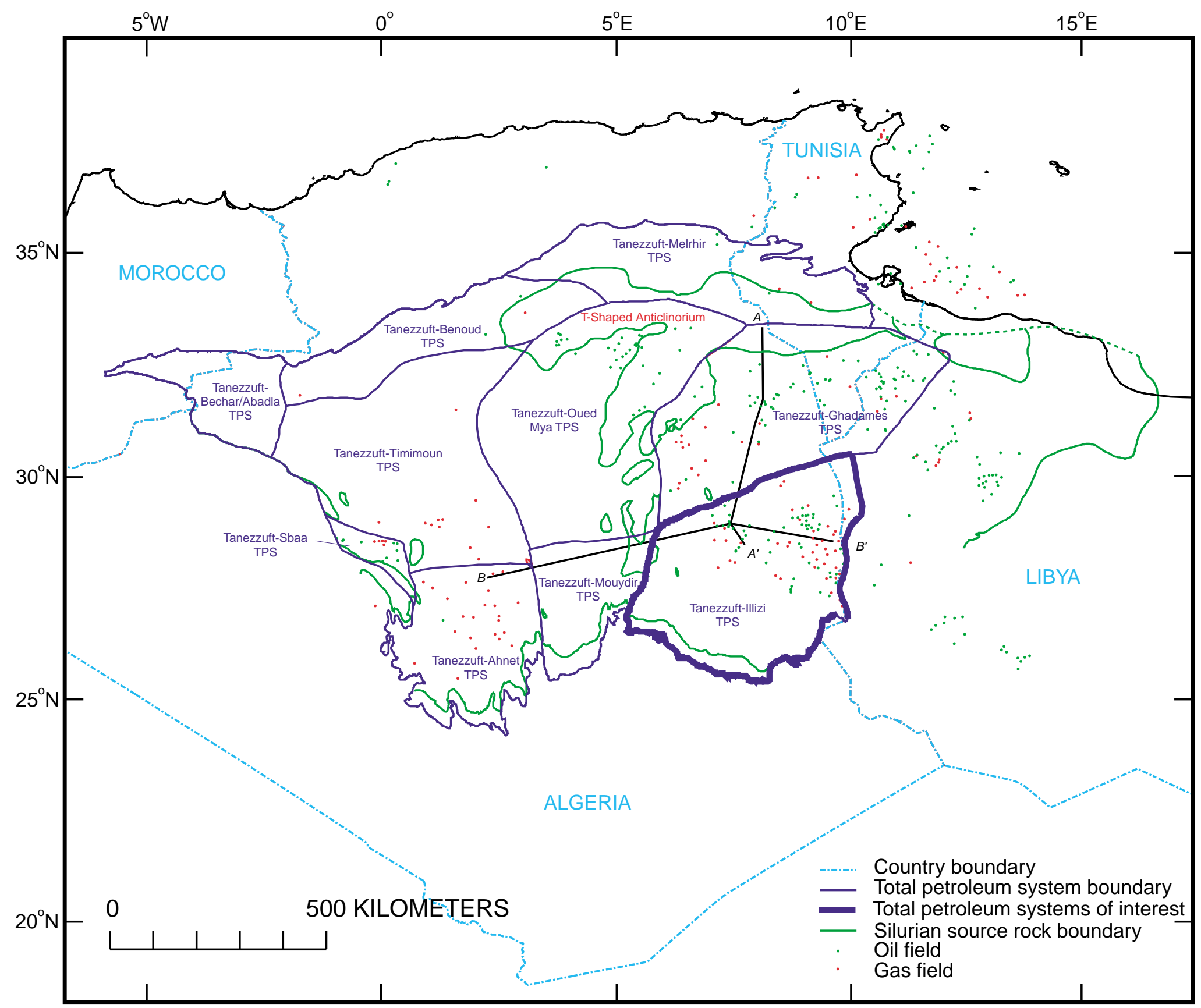

Figure 2. North-central Africa, showing the areal extent of total petroleum systems and Silurian source rocks (Tanezzuft Formation), and locations of stratigraphic cross sections (modified from Petroconsultants, 1996b; Persits and others, 1997; Boote and others, 1998). 
Province contains the giant Tin Fouye-Tabankort and Zarzaitine oil fields.

\section{Province Geology}

The Tanezzuft-Illizi Province coincides with the Illizi Basin and is bounded on the north by the Ghadames (Berkine) Basin, on the east by the Tihemboka Arch, on the south by the Hoggar Massif, and on the west by the Amguid-Hassi Touareg structural axis.

The south-to-north plunging Tihemboka Arch separates the Illizi Basin from the Hamra Basin to the east (fig. 1) and is located near the Algerian-Libyan border. Along the western boundary, the Amguid-Hassi Touareg structural axis separates the Illizi Basin from the Mouydir Basin of the Grand Erg/Ahnet Province.

The boundary between the Illizi and Ghadames (Berkine) Basins is defined by a break or hinge line in the slope of the basement rocks. This hinge line was responsible for separating much of the petroleum generation, migration, and accumulation between the two basins (fig. 4A). The Illizi Basin is presently perched on a basement high and is not as deep as the neighboring Ghadames (Berkine) and Hamra Basins. The Illizi-Ghadames (Berkine) Basin boundary represents the approximate extent of Triassic and Jurassic evaporites that were deposited within the Mesozoic-aged Triassic Basin.

\section{Tectonic History}

The regional stratigraphy is continuous across North Africa, but petroleum generation, migration, and entrapment within each total petroleum system have been controlled by the tectonic history of individual basins. Deformational events in the region, most of them minor, are recorded by unconformities reflecting basin tilting, uplift, and erosion of intracratonic structural axes at various times throughout the Phanerozoic. The main deformational events occurred in the Precambrian to Early Cambrian (Pan African event), Late Silurian to Early Devonian, Late Devonian (Frasnian event), Carboniferous to Permian (Hercynian event), Early Jurassic, Early Cretaceous (Aptian, Austrian event), Late Cretaceous, and Tertiary (Eocene to Oligocene, Pyrenean event) (Aliev and others, 1971; Peterson, 1985; Boudjema, 1987; van de Weerd and Ware, 1994).

Throughout most of the Paleozoic, North Africa was a single depositional basin on the northern shelf of the African craton (Aliev and others, 1971; van de Weerd and Ware, 1994). The basin generally deepened northward where deposition and marine influence were greater (Daniels and Emme, 1995). Some gentle but large structures existed in this area throughout the Paleozoic and affected the thickness of the sedimentary cover (Aliev and others, 1971; van de Weerd and Ware, 1994). There was a general conformity of structure throughout most of the Paleozoic until the Hercynian event. In the Late Silurian and Early Devonian, Laurasia separated from Gondwana resulting in minor deformation, uplift, and local erosion (Aliev and others, 1971; Boote and others, 1998). Many of the basins and uplifts preserved today were initially developed during this event from earlier structures (Peterson, 1985). Later, in the Middle to Late Devonian, the initial collision of Laurasia and Gondwana began resulting in erosion and further modification of preexisting structures (Boote and others, 1998).

Repeated minor uplift of the Tihemboka Arch and AmguidHassi Touareg structural axis occurred in the Late Silurian through the Devonian, with resulting local erosion and gradual development of the Illizi as a discrete basin (Aliev and others, 1971; van de Weerd and Ware, 1994; Boote and others, 1998).

The Hercynian event marks the collision between Laurasia and Gondwana and caused regional uplift, folding, and erosion (Aliev and others, 1971; Boote and others, 1998). Paleozoic basins that were delineated by earlier tectonic events were modified, resulting in the development of several intracratonic sag and foreland basins (Aliev and others, 1971; van de Weerd and Ware, 1994; Boote and others, 1998).

Several transgressive-regressive cycles occurrred throughout the Paleozoic. Two major flooding events, one in the Silurian and the other in the Late Devonian, were responsible for the deposition of source rocks (Aliev and others, 1971; Boudjema, 1987). Many of the prograding fluvial, estuarine, deltaic, and shallow marine sands that were deposited during these cycles are now reservoirs (Aliev and others, 1971).

Some petroleum may have been generated during the Carboniferous Period within the Paleozoic depocenter southwest of the Illizi Basin, but uplift caused petroleum generation to cease. Subsequent erosion probably removed or dispersed most petroleum that had accumulated (Tissot and others, 1973).

During the early Mesozoic, extensional movements caused by the opening of the Tethys and Atlantic oceans developed a cratonic sag basin called the Triassic Basin. The depocenter was superimposed on some of the Paleozoic basins (Aliev and others, 1971; Boudjema, 1987). Triassic fluvial sands followed by a thick Triassic to Jurassic evaporite section were deposited within the sag basin (Aliev and others, 1971; Boudjema, 1987). Sandstones resulting from the fluvial deposition are major reservoirs, and the evaporites provide a regional seal for these fluvial and Paleozoic reservoirs (Aliev and others, 1971). Clastic then carbonate deposition occurred throughout the remainder of the Mesozoic over much of central North Africa (Aliev and others, 1971; Boudjema, 1987). Sediment deposition gradually diminished in the Tertiary over most of the area (Aliev and others, 1971; Peterson, 1985; Boudjema, 1987). Much of the petroleum present in Saharan Africa was generated in the Cretaceous and early Tertiary (Daniels and Emme, 1995; Makhous and others, 1997).

Transpressional movements (wrenching) during Austrian deformation reactivated older structures such as those along the Tihemboka Arch and Amguid-Hassi Touareg structural axis, causing local uplift and erosion (Claret and Tempere, 1967; Aliev and others, 1971). The southern portion of the Illizi Basin was unroofed at this time and was never again reburied (Macgregor, 1998; Boote and others, 1998; van de Weerd and Ware, 1994).

The initial stages of the Africa-Arabia and Eurasia collision during Late Cretaceous to middle Tertiary caused compressional movements and uplift (Peterson, 1985; Guiraud, 1998). These movements tilted the Triassic Basin to its present configuration (Aliev and others, 1971; Boote and others, 1998). 


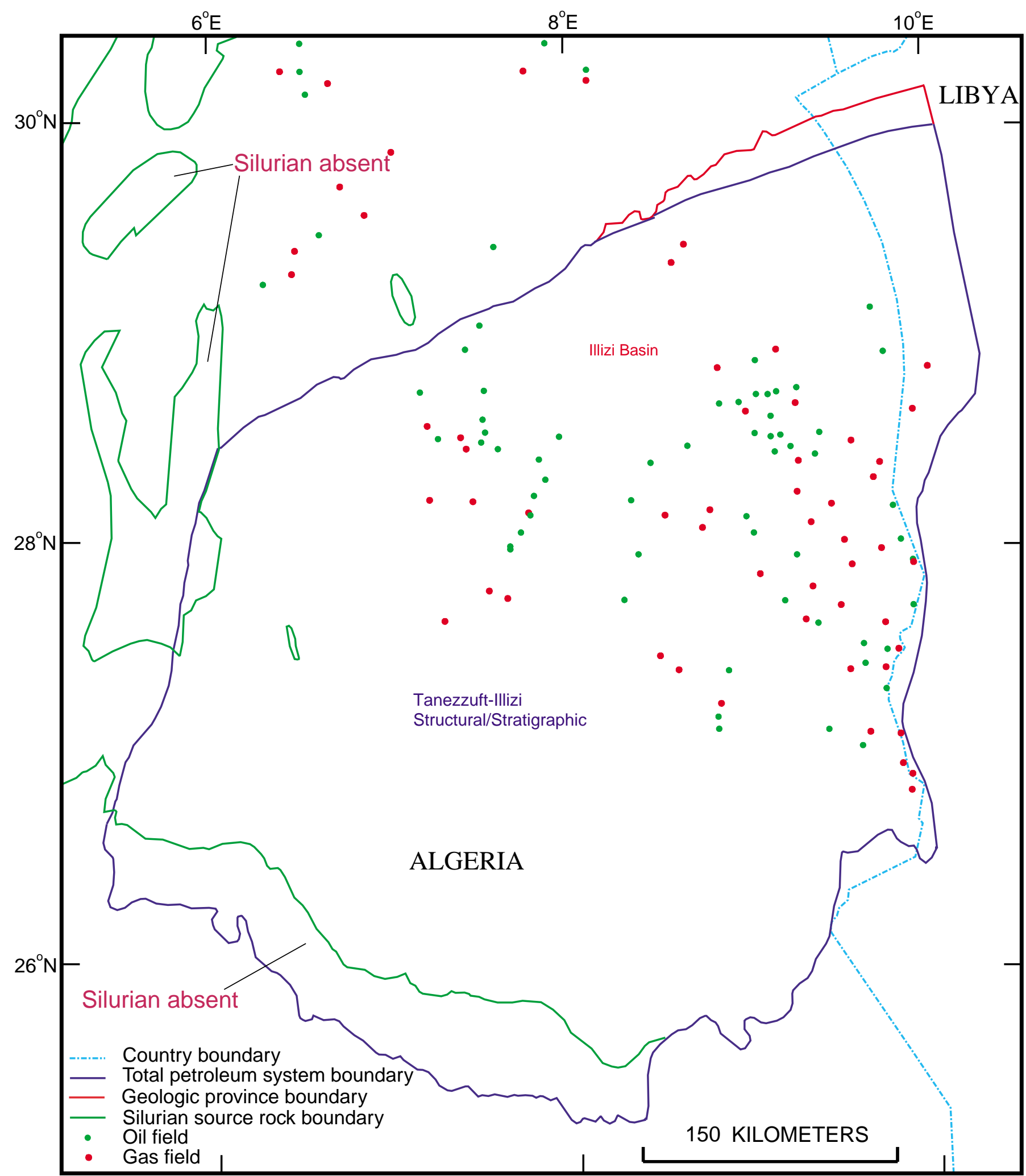

Figure 3. Areal extent of assessment units within the Illizi Province (modified from Petroconsultants, 1996b; Persits and others, 1997). 


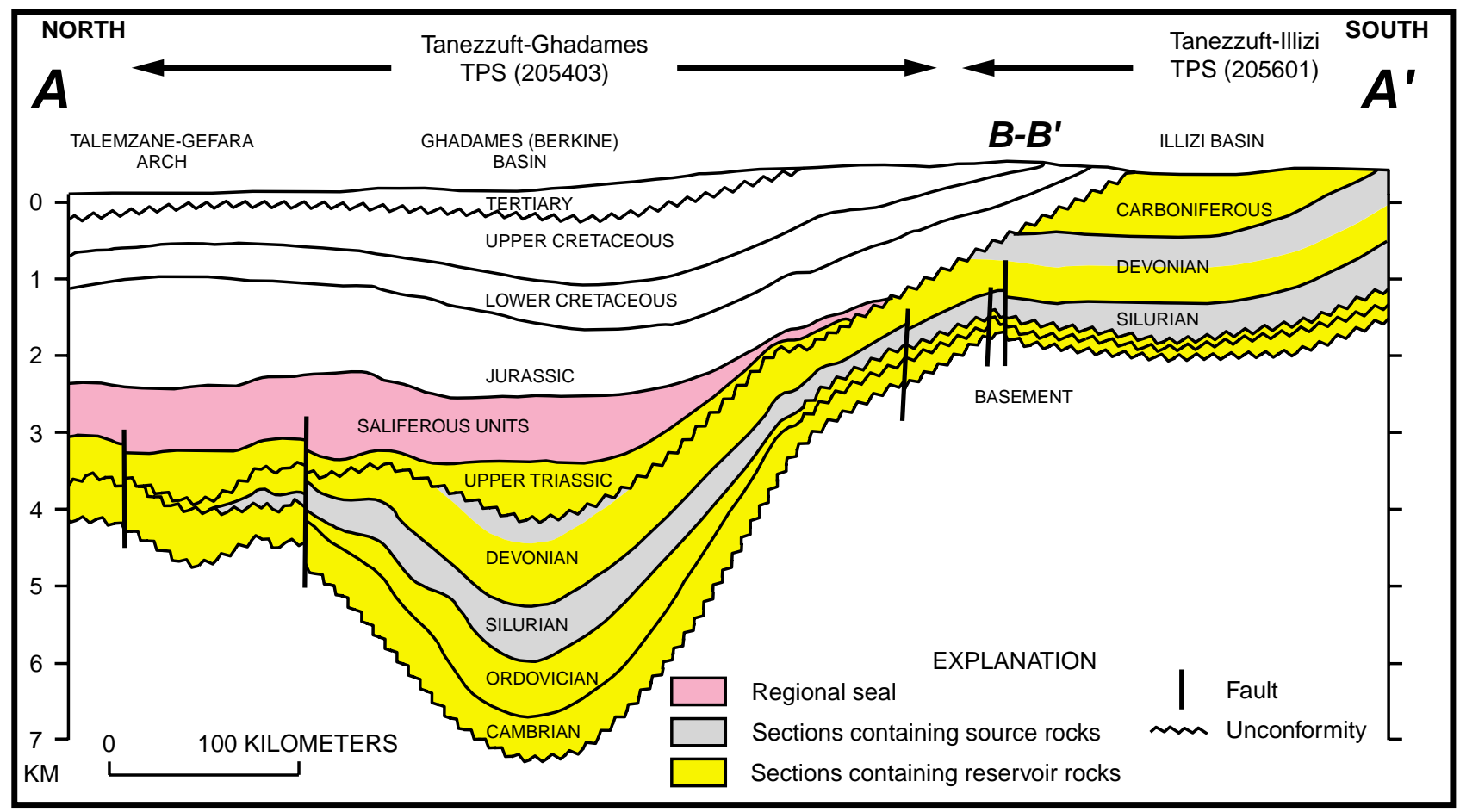

A

Figure 4. Stratigraphic cross sections through Trias/Ghadames and Illizi Provinces. $A$, North-to-south stratigraphic cross section through the Ghadames (Berkine) and Illizi Basins (modified from van de Weerd and Ware, 1994, after Aliev and others, 1971).

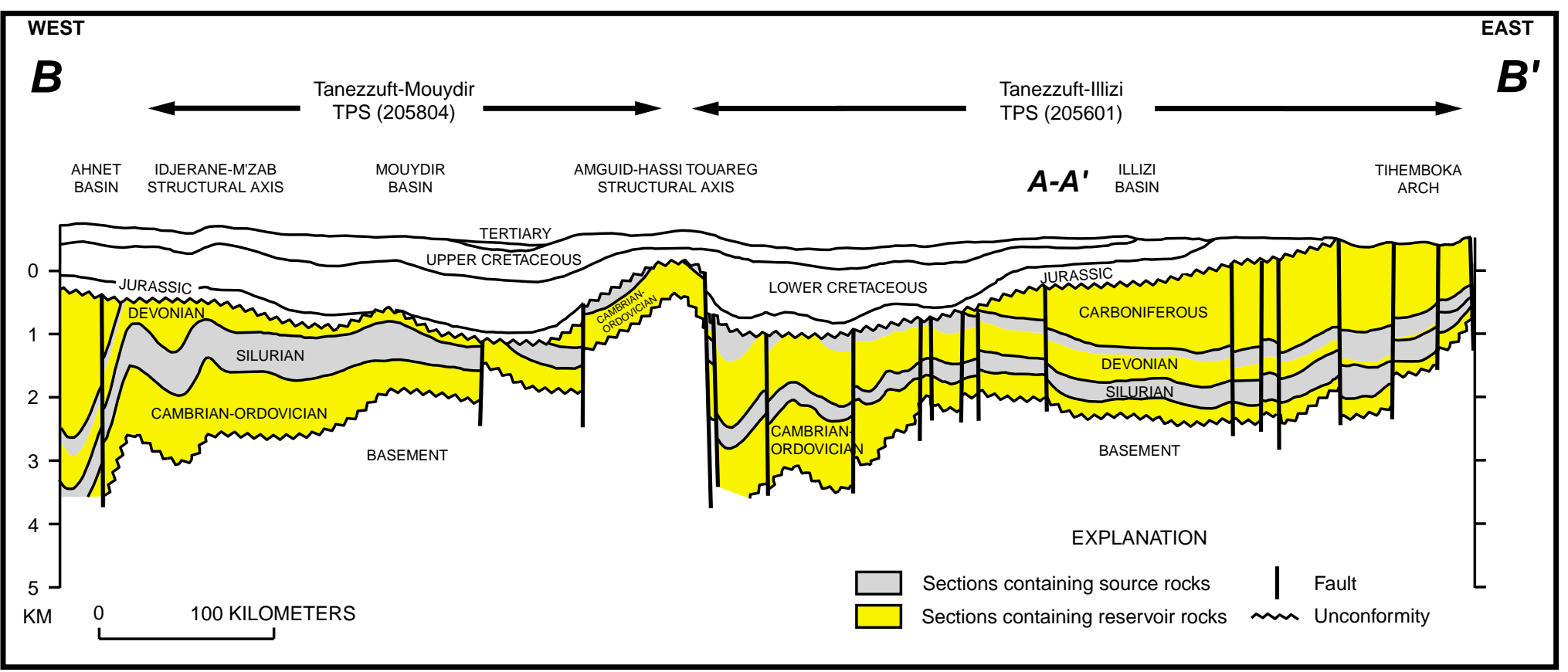

$B$

Figure 4-Continued. Stratigraphic cross sections. B, West-to-east stratigraphic cross section through the Mouydir and Illizi Basins (modified from Makhous and others, 1997). 
Petroleum was generated within the Illizi Basin from the Middle to Late Jurassic to early Tertiary (Daniels and Emme, 1995). Some spillage or secondary migration occurred (Boote and others, 1998; van de Weerd and Ware, 1994). Many of the structural traps were formed by vertical movements of the basement during Mesozoic and Tertiary deformational events (Echikh, 1998).

\section{Stratigraphy}

The regional stratigraphy of lower Paleozoic sections is generally continuous, but the Devonian and overlying sections show more localized depositional systems. Stratigraphic nomenclature varies among the Saharan basins and countries. This study primarily uses nomenclature given in Boudjema (1987), Montgomery (1993), and Echikh (1998). Columnar sections, stratigraphic nomenclature, and correlations are shown in figure 5.

Principal source rocks are the Silurian Tanezzuft Formation and Middle to Upper Devonian mudstone (Givetian to Famennian) (Tissot and others, 1973; Daniels and Emme, 1995). Other minor or relatively unimportant source rocks are also present but contributed significantly less petroleum than did the Silurian or Middle to Upper Devonian mudstone (Daniels and Emme, 1995; Boote and others, 1998). Reservoir rocks include sandstone of Cambrian-Ordovician, Silurian, Devonian, and Carboniferous age. Intraformational Paleozoic marine mudstone provides the primary seals.

During the late Precambrian and Early Cambrian, erosion of a preexisting craton to the south occurred due to uplift during the Pan African deformational event. Eroded sediments were deposited northward as alluvial and fluvial deposits and make up the thick Cambrian sandstone of the Hassi Leila Formation. The Hassi Leila Formation and its lateral equivalents, the Hassaouna and Hassi Messaoud Formations, are major oil and gas reservoirs (Petroconsultants, 1996a; van de Weerd and Ware, 1994).

The Lower Ordovician In Kraf Formation unconformably overlies the Hassi Leila Formation. The In Kraf Formation contains mudstone and sandstone laterally equivalent to the Zone des Alterances, Argile d'El Gassi, and Gres d'El Atchane Formations of the Triassic Basin (fig. 5). The Argile d'El Gassi and equivalents may be locally minor source rocks (Makhous and others, 1997; Malla and others, 1997).

Overlying the In Kraf Formation is the quartz-rich, marine to marginal marine sandstone of the Hamra Formation (van de Weerd and Ware, 1994). Above the Hamra Formation is the Middle Ordovician Edjeleh Formation. The Edjeleh Formation is a marine sandstone that is a local facies of the Argiles d'Azzel mudstone (D. Boote, oral commun., 1999). Both the Hamra and Edjeleh Formations are important oil and gas reservoirs in the Illizi Province. Upper Ordovician to Lower Silurian marine and glacial mudstone and fine-grained sandstone of the Gara Louki Formation overlie the Edjeleh Formation.

Overlying the Gara Louki Formation is the organic-rich, graptolitic, marine mudstone of the Silurian Tanezzuft Formation. In the Illizi Basin, the Tanezzuft is sometimes referred to as "Argileux." The Tanezzuft Formation, a principal source rock, was deposited during a major regional flooding event and contains mostly sapropelic and mixed (type I and II) kerogen (Daniels and Emme, 1995; Makhous and others, 1997). The present-day total organic carbon (TOC) content ranges from less than 2 to 9 percent across the Illizi Basin, but may be reduced by as much as one-half due to increased thermal maturity (Daniels and Emme, 1995). The TOC content is greatest at the base of the section (Daniels and Emme, 1995). The thickness, richness, and kerogen type of this source rock are regionally variable and dependent on paleogeography (Daniels and Emme, 1995). The thickness of the Tanezzuft Formation, before Hercynian erosion, ranged from about $200 \mathrm{~m}$ to greater than 500 m (Boote and others, 1998).

The Tanezzuft Formation grades upward into sandstone and mudstone of the Silurian Zone de Passage. These sediments were deposited in marine to marginal marine environments and are laterally equivalent to the Acacus sandstone.

Devonian rocks unconformably overlie the Upper Silurian sediments. Devonian rocks consist of interbedded marine sandstone and mudstone. Sandstone members within the Devonian section are each given a code, F2 to F6 with F6 being the oldest and F2 the youngest (fig. 5). These sandstone members are principal oil and gas reservoirs in the Illizi Province.

Middle to Upper Devonian mudstone is another major source rock, particularly the Frasnian-aged mudstone, which is the richest in this interval (Daniels and Emme, 1995). This mudstone, like the Silurian Tanezzuft Formation, was deposited during a major regional flooding event and contains mostly sapropelic and mixed (type I and II) kerogen (Daniels and Emme, 1995; Makhous and others, 1997). Distribution of richness and kerogen type were presumably controlled by paleogeography. The present-day TOC content generally ranges from about 2 to 4 percent but can reach 7 percent (Daniels and Emme, 1995). Thickness of Middle to Upper Devonian mudstone ranges from about $200 \mathrm{~m}$ to more than $400 \mathrm{~m}$ near the Hoggar Massif (Daniels and Emme, 1995).

The Lower to lower Middle Carboniferous rocks consist of cycles of limestone or mudstone, siltstone, sandstone, and conglomerate representing deltaic and shallow marine deposition. Upper Middle to Upper Carboniferous rocks consist of limestones, marls, dolostones, and gypsiferous mudstone that were deposited in evaporitic shallow-marine and tidal environments. As with Devonian rocks, Carboniferous formations are divided into members, each having a code from A to F, with A being the oldest and $\mathrm{F}$ the youngest (fig. 5).

No Permian rocks are present in the Illizi Province. Hercynian deformation started during the Late Carboniferous and continued into the Early Permian. Uplift caused deep erosion of Carboniferous through Devonian sections on the bounding structural highs and the basin began to assume its modern form.

The lower Mesozoic transgression, which swept across the eroded Hercynian peneplain from the northeast, did not reach the Illizi Province until very Late Triassic and Jurassic. The Triassic to Lower Cretaceous section is represented by nonmarine clastic rocks passing up into marginal marine clastics and then

Figure 5 (next two pages). Columnar section and stratigraphic nomenclature for Illizi, Triassic, and Ghadames (Berkine) Basins (modified from Boudjema, 1987). Major reservoir rocks are shown in yellow, source rocks in gray, and seals in red. 


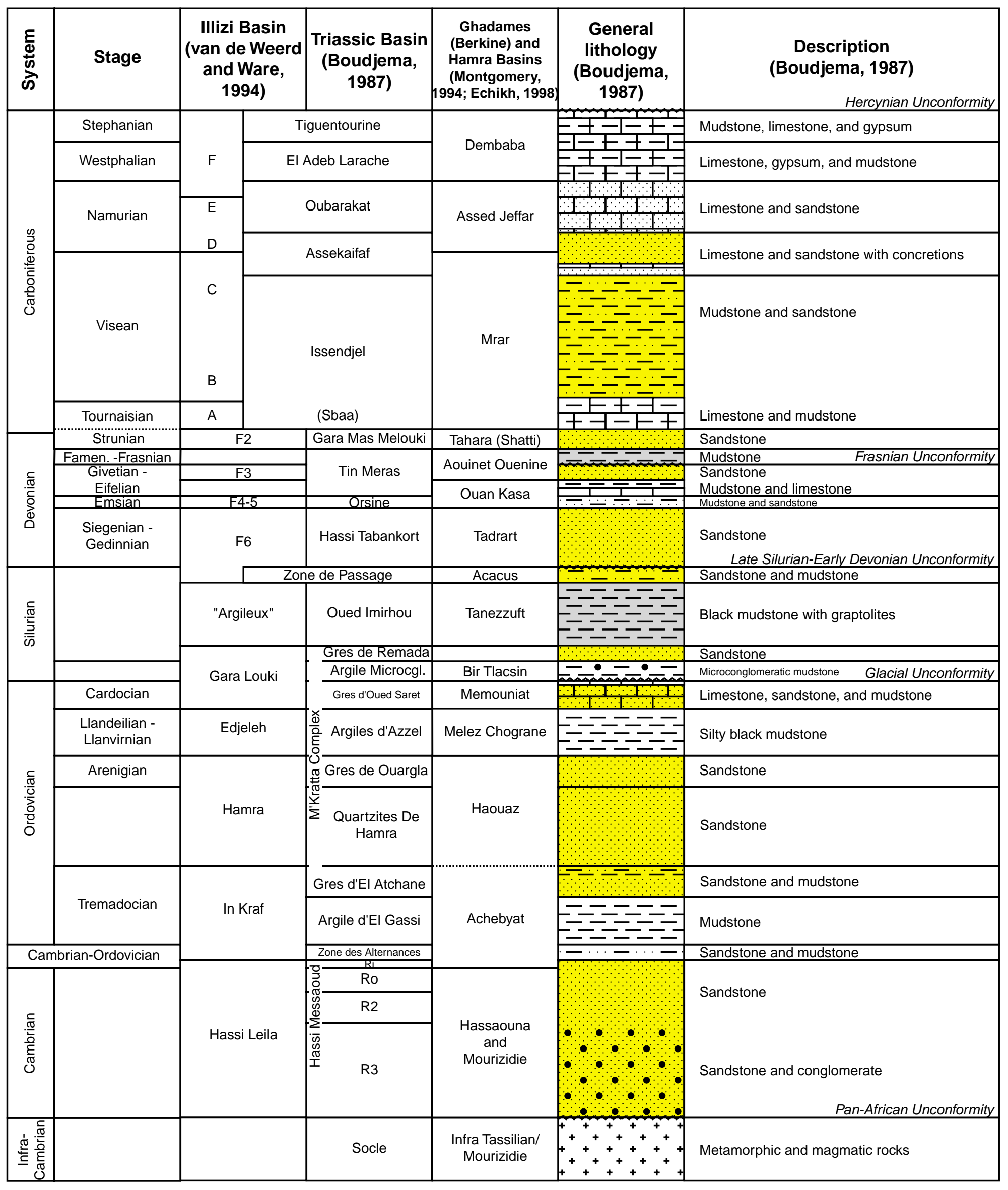




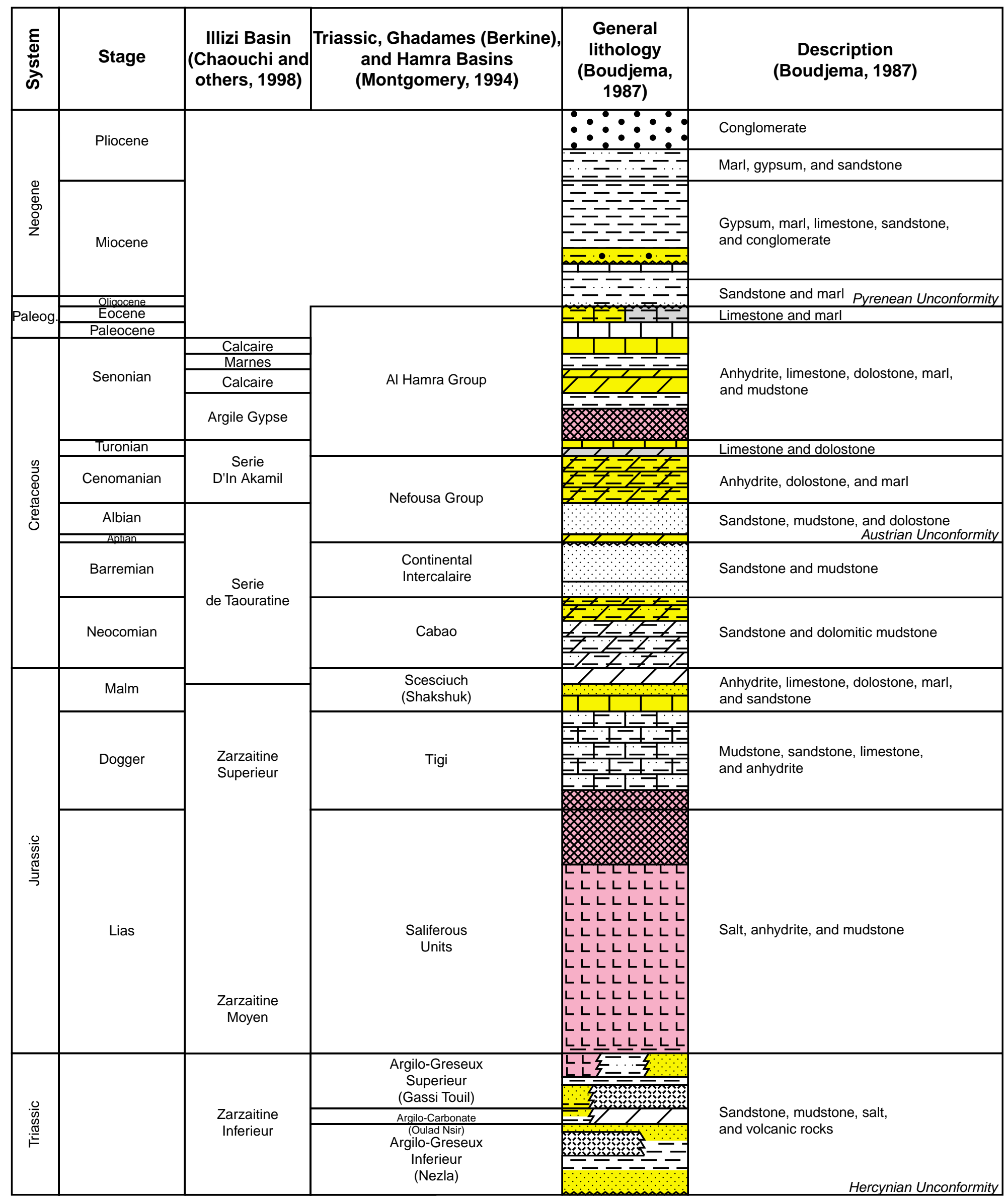


into marine carbonate rocks forming a north-facing sedimentary wedge. The Cenozoic section is represented by thin, discontinuous Miocene-Pliocene nonmarine rocks and Quaternary sediments.

\section{Petroleum Occurrence}

Most of the oil and gas fields found by the end of 1995 in the Illizi Province are located in the north-central part of the Illizi Basin and along the Tihemboka Arch, near the Triassic Basin where Mesozoic generation and migration occurred. Most of these accumulations are within low-relief, commonly faulted anticlines (Boote and others, 1998; Petroconsultants, 1996a). The number of accumulations in the southern and western portions of the province had been destroyed by uplift, inactive generation, erosion of reservoir and seal rocks, and water flushing during and following Hercynian deformation (Boote and others, 1998; Macgregor, 1998). There is a lower potential for new discoveries in these areas compared to the northern and eastern portions of the Illizi Basin.

\section{Regional Exploration History}

Exploration activity in Algeria fluctuated through time due to its war for independence from 1954 to 1962, nationalization of the oil industry from 1963 to 1971 , and political and economic problems into the 1980's (Traut and others, 1998; Montgomery, 1994). Libya also experienced fluctuations and discontinuities. Between 1963 and late 1980's, Algeria had legislation regarding concession contracts and royalties that discouraged exploration by foreign companies (Montgomery, 1994). Since the late 1980's, however, Algeria revised its legislation, encouraging foreign companies to explore and develop oil and gas resources (Davies and Bel Haiza, 1990;

SONATRACH, c. 1992; Montgomery, 1994; Traut and others, 1998).

Not all areas in Algeria and Libya were accessible for exploration. Shifting sand of Saharan African deserts presents technical difficulties in exploration and hazards in production operations (Echikh, 1998). Since the 1980's, some of these technical difficulties in exploration have been resolved. Recent advances in gathering, processing, and reprocessing of seismic data allow exploration beneath sand-sea environments such as the Algerian Grand Erg Oriental where the Ghadames (Berkine) and Illizi Basins lie (van de Weerd and Ware, 1994; Macgregor, 1998).

New discoveries can be easily brought on line without construction of major pipelines because a basic infrastructure has been established (SONATRACH, c. 1992). Algeria has an extensive pipeline network that connects most of the major producing areas to port cities in Algeria and Tunisia (Pennwell, 1996). The pipelines allow transportation of oil, gas, and natural gas liquids. In Libya, an oil pipeline connects fields of the Ghadames (Berkine) and Hamra Basins to the port city of Az Zawiyah. An extension of this pipeline was completed in 1996 that connects producing areas within the Murzuk Basin with the coast (Traut and others, 1998; Pennwell, 1996), and another pipeline is planned to connect the Libyan portion of the Trias/ Ghadames Province to the coast (Arab Petroleum Research Center, 1996).

\section{The Tanezzuft-IIlizi Total Petroleum System (205601)}

The Tanezzuft-Illizi Total Petroleum System is coincident with most of the Illizi Basin and Province. Paleozoic rocks, including the major source rocks, crop out along the Hoggar Massif (figs. 2 and 3). An events chart (fig. 6) summarizes the timing of sources, reservoirs, seals, trap development, and generation and migration of petroleum. Table 1 shows the formation names, ages, and lithology for abbreviations used in the events chart.

\section{Source Rocks}

The principal source rocks in the Tanezzuft-Illizi Total Petroleum System are the Silurian Tanezzuft Formation and Middle to Upper Devonian mudstone (Tissot and others, 1973; Daniels and Emme, 1995). In the Illizi Basin, the present-day TOC content of the Silurian Tanezzuft source rock typically ranges from 0.5 to 8 percent, but can be as much as 16 percent (Daniels and Emme, 1995; Makhous and others, 1997). Middle to Upper Devonian source rocks typically contain from 2 to 8 percent TOC (Daniels and Emme, 1995; Makhous and others, 1997). Equivalent vitrinite reflectance of Silurian source rocks ranges from 1.1 to 1.75 percent (Daniels and Emme, 1995) and the Middle to Upper Devonian, 1.1 to 1.3 percent $\mathrm{R}_{\mathrm{o}}$ (Daniels and Emme, 1995). In the north-central, central, and southeastern portions of the total petroleum system, Silurian and Middle to Upper Devonian source rocks are presently in the peak to late oil generation phase (Daniels and Emme, 1995). In the northeastern portion, both source rocks are presently in the late oil to wet gas generation phase (Daniels and Emme, 1995). Silurian source rocks in the south and southwestern portions are presently in the wet to possibly the dry gas generation phase, whereas Devonian source rocks are presently in the late oil generation phase (Daniels and Emme, 1995).

Oil generation from both Silurian and Middle to Upper Devonian source rocks in the southern and western portion of the total petroleum system probably started and reached peak generative phases in the Carboniferous, but generation was halted during the Hercynian deformational event (Tissot and others, 1973; Daniels and Emme, 1995). Erosion resulting from Hercynian deformation probably removed most or all of the petroleum generated prior to the Hercynian event, and the source rocks in this portion of the total petroleum system were never again sufficiently buried to resume generation (Tissot and others, 1973). Hercynian deformation was followed by Mesozoic subsidence and deposition to the north, which resulted in petroleum generation in the central, northern, and eastern portions of the total petroleum system (Tissot and others, 1973). Oil generation 


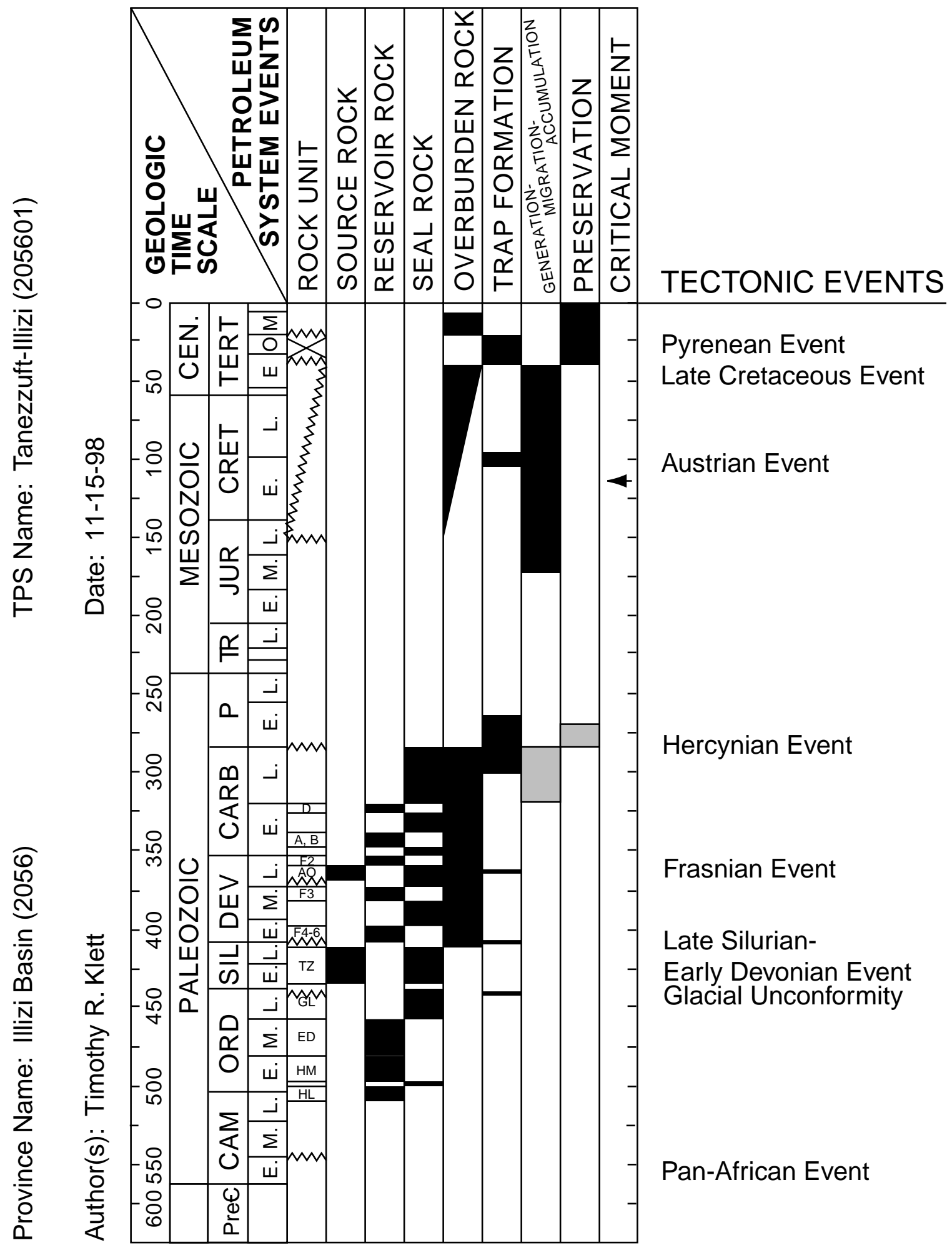

Figure 6. Events chart for Tanezzuft-Illizi Total Petroleum System. Names for abbreviations used in rock unit column are given in table 1. Gray boxes indicate secondary or possible occurrences. 
from Silurian source rocks in the central and southeastern portions of the total petroleum system peaked during the middle Cretaceous, whereas in the northern and eastern portions, generation probably peaked during the Middle to Late Jurassic (Daniels and Emme, 1995). Oil generation from Middle to Upper Devonian source rocks peaked during the Eocene in the central portion of the total petroleum system and Early to Late Cretaceous in the northern and eastern portions (Daniels and Emme, 1995). Petroleum most likely migrated laterally into adjacent or juxtaposed migration conduits and reservoirs. Some vertical migration occurred along faults or fractures in structurally deformed areas (Boote and others, 1998).

\section{Overburden Rocks}

Overburden rocks are variable across the area mainly due to nondeposition and erosion during the Hercynian, Austrian, and Pyrenean deformational events (fig. $4 A$ and $B$ ). Carboniferous and Mesozoic rocks comprise most of the overburden for the Tanezzuft-Illizi Total Petroleum System. Large portions of Paleozoic section were removed by erosion during Hercynian deformation. Mesozoic rocks thin southward as a result of both original deposition and Tertiary uplift and unroofing in the south. As a result, Paleozoic rocks are thickest in the center of the basin (approximately 2,500 m, while the Mesozoic is thickest to the north and west (fig. 4A and $B$ ) (Bishop, 1975; Chiarelli, 1978; Boudjema, 1987; Montgomery, 1993; D. Boote, oral commun., 1999). A thin Cenozoic section is present over the northern part of the total petroleum system.

\section{Reservoir Rocks}

The primary known reservoir rocks in the Tanezzuft-Illizi Total Petroleum System are Devonian sandstone. Devonian reservoirs include paralic to marine sandstone of the F2, F3, F4, F5, and F6 members (Petroconsultants, 1996a). Other known reservoir rocks include Cambrian-Ordovician, Silurian, and Carboniferous sandstone. Cambrian-Ordovician reservoirs include fluvial to marine sandstone of the Hassi Leila Formation, Hamra Formation, and marine and glacial sandstone of the Edjeleh Formation (Petroconsultants, 1996a, van de Weerd and Ware, 1994). Carboniferous reservoirs include the deltaic to marine sandstone of the B and D members, and Issendjel and Mrar Formations (Petroconsultants, 1996a). Only a few unnamed Silurian marine sandstone reservoirs are known (Petroconsultants, 1996a). Names of laterally equivalent rock units are shown in figure 5, and known reservoir properties are given in table 2 .

\section{Seal Rocks}

Intraformational Paleozoic marine mudstone is the primary seal for reservoirs in the Tanezzuft-Illizi Total Petroleum System (Boote and others, 1998). Triassic to Jurassic evaporites, mudstone, and carbonate rocks that provide a regional top seal for reservoirs in the Ghadames (Berkine) Basin do not extend into the Illizi Province.

\section{Trap Types in Oil and Gas Fields}

Most of the accumulations discovered prior to 1996 are within anticlines and faulted anticlines (Echikh, 1998; Boote and others, 1998; Petroconsultants, 1996a, van de Weerd and Ware, 1994). Accumulations within combination traps are present in the Illizi Basin. These are generally unconformity-related reservoir pinchouts across Hercynian or Austrian structures (Echikh, 1998). Hydrodynamic traps may also be present but are not common (Echikh, 1998; Chiarelli, 1978; Aliev and others, 1971). Accumulations within one of the largest oil fields of the Illizi Basin, Tin Fouye-Tabankort, are presumed hydrodynamically trapped (Echikh, 1998; Alem and others, 1998).

\section{Assessment of Undiscovered Petroleum by Assessment Unit}

One assessment unit was identified for the Tanezzuft-Illizi Total Petroleum System, called Tanezzuft-Illizi Structural/Stratigraphic Assessment Unit (fig. 3). As of 1996, it contained 102 fields. Of these discovered fields, 51 are oil fields, 38 are gas fields, and 13 fields are not classified because they contain less than 1 million barrels of oil equivalent (MMBOE) (based on USGS oil and gas field definitions). Combined, these fields contain 3,670 MMBO, 45,061 BCFG, and $898 \mathrm{MMBNGL}$, as known volumes (table 3) (Petroconsultants, 1996a). Minimum field sizes of $10 \mathrm{MMBO}$ or $60 \mathrm{BCFG}$ were chosen for this assessment unit based on the field-size distribution of discovered fields.

The exploration density as of 1996 was 16 new-field wildcat wells per $10,000 \mathrm{~km}^{2}$. The overall success rate as of 1996 was 32 discoveries per 100 new-field wildcat wells (or about one discovery per three new-field wildcat wells). The success rate in terms of discoveries per number of new-field wildcat wells drilled remained relatively constant through time. Plots showing exploration activity and discovery history are presented in the appendix at the end of this report.

Exploration activity was not consistent through time: peaks occurred from the late 1950's to mid-1960's, in the early 1970's, and in the mid-1980's. The first major discoveries were the Edjeleh field in 1956 and the Zarzaitine field in 1957. Little exploration occurred and few discoveries were made between the early 1970's and 1990. The sizes of discovered oil and gas fields have decreased somewhat through time and with respect to exploration activity. Some large accumulations are still being discovered, however. Exploration appears to be moderately mature across much of the area.

Until recently, only structural traps have been explored for oil and gas. Continued exploration of structural and combination traps is expected for the next 30 years. New exploration concepts could include the search for both structural and stratigraphic traps. Potential exists for the discovery of hydrodynamic traps along the flanks of structures that have already been explored (Chiarelli, 1978).

This study estimates that about one-third of the total number of fields (discovered and undiscovered) of at least the minimum size have been discovered. The estimated median 
size and number of undiscovered oil fields are $25 \mathrm{MMBO}$ and 67 fields; the same values for undiscovered gas fields are 200 BCFG and 45 fields. The ranges of number, size, and coproduct-ratio estimates for undiscovered fields are given in table 4.

The estimated means of the undiscovered conventional petroleum volumes are 2,814 MMBO, 27,785 BCFG, and 873 MMBNGL (table 5). In addition, the mean largest anticipated undiscovered oil and gas fields are $222 \mathrm{MMBO}$ and 1,842 BCFG, respectively.

\section{Summary}

One total petroleum system and a corresponding assessment unit were identified, both coinciding with the Illizi Basin. This total petroleum system is called the Tanezzuft-Illizi.

The primary source rocks are the Silurian Tanezzuft Formation and Middle to Upper Devonian mudstone. In the southern and western portions, the source rocks reached peak generative phases during the Carboniferous. Elsewhere, peak oil generation occurred from the Middle to Late Jurassic to the Eocene. The primary reservoir rocks include Cambrian-Ordovician, Silurian, Devonian, and Carboniferous sandstone. Intraformational Paleozoic marine mudstone is the primary seal. Most of the known accumulations are within anticlines and faulted anticlines.

The estimated means of the undiscovered conventional petroleum volumes in the Tanezzuft-Illizi Total Petroleum System are 2,814 MMBO, 27,785 BCFG, and 873 MMBNGL.

\section{References Cited}

Alem, N., Assassi, S., Benhebouche, S., and Kadi, B., 1998, Controls on hydrocarbon occurrence and productivity in the F6 reservoir, Tin Fouyé-Tabankort area, NW Illizi Basin, in Macgregor, D.S., Moody, R.T.J., and Clark-Lowes, D.D., eds., Petroleum geology of North Africa: Geological Society, London, Special Publication 132, p. 175-186.

Aliev, M., Aït Laoussine, N. A., Avrov, V., Aleksine, G., Barouline, G., lakovlev, B., Korj, M., Kouvykine, J., Makarov, V., Mazanov, V., Medvedev, E., Mkrtchiane, 0., Moustafinov, R., Oriev, L., Oroudjeva, D., Oulmi, M., and Saïd, A., 1971, Geological structures and estimation of oil and gas in the Sahara in Algeria: Spain, Altamira-Rotopress, S. A., $265 \mathrm{p}$.

Arab Petroleum Research Center, 1996, Arab Oil and Gas Directory: Paris, France, Arab Petroleum Research Center, 615 p.

Bishop, W.F., 1975, Geology of Tunisia and adjacent parts of Algeria and Libya: American Association of Petroleum Geologists Bulletin, v. 59, no. 3, p. 413-450.

Boote, D.R.D., Clark-Lowes, D.D., and Traut, M.W., 1998, Palaeozoic petroleum systems of North Africa, in Macgregor, D.S., Moody, R.T.J., and Clark-Lowes, D.D., eds., Petroleum geology of North Africa: Geological Society, London, Special Publication 132, p. 7-68.

Boudjema, A., 1987, Evolution structurale du bassin petrolier "Triasique" du Sahara Nord Oriental (Algerie): Thèse a l'Université de Paris-Sud, Centre d'Orsay, $290 \mathrm{p}$.
Burollet, P.F., Mugniot, J.M., and Sweeney, P., 1978, The geology of the Pelagian block: The margins and basins off southern Tunisia and Tripolitania, in Nairn, A.E.M., Kanes, W.H., and Stehli, F. G., eds., The ocean basins and margins: New York, Plenum Press, v. 4B, p. 331359.

Chaouchi, R., Malla, M.S., and Kechou, F., 1998, Sedimentological evolution of the Givetian-Eifelian (F3) sand bar of the West Alrar field, Illizi Basin, Algeria, in Macgregor, D.S., Moody, R.T.J., and Clark-Lowes, D.D., eds., Petroleum geology of North Africa: Geological Society, London, Special Publication 132, p. 187-200.

Chiarelli, A., 1978, Hydrodynamic framework of Eastern Algerian Sahara - Influence on hydrocarbon occurrence: American Association of Petroleum Geologists Bulletin, v. 62, no. 4, p. 667-685.

Claret, J., and Tempere, C., 1967, Une nouvelle region productrice au Sahara Algerien; I'anticlinorium d'Hassi Touareg: Proceedings of the Seventh World Petroleum Congress, v. 2, Origin of oil, geology and geophysics, p. 81-100.

Daniels, R.P., and Emme, J.J., 1995, Petroleum system model, eastern Algeria, from source rock to accumulation; when, where, and how?: Proceedings of the Seminar on Source Rocks and Hydrocarbon Habitat in Tunisia; Entreprise Tunisienne d'Activités Petrolieres Memoir 9, p. 101-124.

Davies, W.C., and Bel Haiza, A., 1990, Sweeter E and P terms, Cretaceous Abiod chalk oil play lead to busier exploration in Tunisia: Oil and Gas Journal, December 10, p. 50-53.

Echikh, K., 1998, Geology and hydrocarbon occurrences in the Ghadames Basin, Algeria, Tunisia, and Libya, in Macgregor, D.S., Moody, R.T.J., and Clark-Lowes, D.D., eds., Petroleum geology of North Africa: Geological Society, London, Special Publication 132, p. 109-129.

Guiraud, R., 1998, Mesozoic rifting and basin inversion along the northern African Tethyan margin-An overview, in Macgregor, D.S., Moody, R.T.J., and Clark-Lowes, D.D., eds., Petroleum geology of North Africa: Geological Society, London, Special Publication 132, p. 217-229.

Klett, T.R., Ahlbrandt, T.S., Schmoker, J.W., and Dolton, G.L., 1997, Ranking of the world's oil and gas provinces by known petroleum volumes: U.S. Geological Survey Open-File Report 97-463, 1 CD-ROM.

Lore, G.L., Brooke, J.P., Cooke, D.W., Klazynski, R.J., Olson, D.L., and Ross, K.M., 1996, Summary of the 1995 assessment of conventionally recoverable hydrocarbon resources of the Gulf of Mexico and Atlantic Outer Continental Shelf: Minerals Management Service OCS Report MMS 96-0047, 67 p.

Macgregor, D.S., 1998, Giant fields, petroleum systems and exploration maturity of Algeria, in Macgregor, D.S., Moody, R.T.J., and ClarkLowes, D.D., eds., Petroleum geology of North Africa: Geological Society, London, Special Publication 132, p. 79-96.

Magoon, L.B., and Dow, W.G., 1994, The petroleum system, in Magoon, L.B., and Dow, W.G., eds., The petroleum system-From source to trap: American Association of Petroleum Geologists Memoir 60, p. 3-24.

Makhous, M., Galushkin, Y., and Lopatin, N., 1997, Burial history and kinetic modeling for hydrocarbon generation, part II, Applying the GALO model to Saharan basins: American Association of Petroleum Geologists Bulletin, v. 81, no. 10, p. 1679-1699.

Malla, M.S., Khatir, B., and Yahi, N., 1997, Review of the structural evolution and hydrocarbon generation in Ghadames and Illizi Basins: Proceedings of the 15th World Petroleum Congress, p. 1-11.

Montgomery, S., 1993, Ghadames Basin of north central Africa; Stratigraphy, geologic history, and drilling summary: Petroleum Frontiers, v. 10, no. 3,51 p. 
1994, Ghadames Basin and surrounding areas; Structure, tectonics, geochemistry and field summaries: Petroleum Frontiers, v. 10, no. $4,79 \mathrm{p}$.

Pennwell Publishing Company, 1996, International petroleum encyclopedia: Tulsa, Okla., Pennwell Publishing Company, v. 29, 335 p.

Persits, F., Ahlbrandt, T., Tuttle, M., Charpentier, R., Brownfield, M., and Takahashi, K., 1997, Maps showing geology, oil and gas fields and geologic provinces of Africa: U.S. Geological Survey Open-File Report 97-470A, CD-ROM.

Peterson, J.A., 1985, Geology and petroleum resources of north-central and northeastern Africa: U.S. Geological Survey Open-File Report 85-709, $54 \mathrm{p}$.

Petroconsultants, 1996a, Petroleum exploration and production database: Houston, Tex., Petroconsultants, Inc. [database available from Petroconsultants, Inc., P.O. Box 740619, Houston, TX 772740619].

1996b, PetroWorld 21: Houston, Tex., Petroconsultants, Inc. [database available from Petroconsultants, Inc., P.0. Box 740619, Houston, TX 77274-0619].
Schmoker, J.W., and Crovelli, R.A., 1998, A simplified spreadsheet program for estimating future growth of oil and gas reserves: Nonrenewable Resources, v. 7, no. 2, p. 149-155.

SONATRACH, c. 1992, Exploration in Algeria: Algeria, Sur Presses Speciales U.A.F.A., $36 \mathrm{p}$.

Tissot, B., Espitalié, J., Deroo, G., Tempere, C., and Jonathan, D., 1973, Origin and migration of hydrocarbons in the eastern Sahara (Algeria): 6th International Meeting of Organic Geochemistry, reprinted in Demaison, G., and Murris, R.J., eds., Petroleum geochemistry and basin evaluation, American Association of Petroleum Geologists Memoir 25, p. 315-334.

Traut, M.W., Boote, D.R.D., and Clark-Lowes, D.D., 1998, Exploration history of the Palaeozoic petroleum systems of North Africa, in Macgregor, D.S., Moody, R.T.J., and Clark-Lowes, D.D., eds., Petroleum geology of North Africa: Geological Society, London, Special Publication 132, p. 69-78.

van de Weerd, A.A., and Ware, P.L.G., 1994, A review of the East Algerian Sahara oil and gas province (Triassic, Ghadames and Illizi Basins): First Break, v. 12, no. 7, p. 363-373. 
Table 1. Abbreviations, names, ages, and lithology of formations used in the total petroleum system events chart.

\begin{tabular}{llll}
\hline Code & Formation name & Age & Lithology \\
\hline A, B & $\begin{array}{l}\text { A and B Sandstone } \\
\text { Members }\end{array}$ & Lower Carboniferous & Sandstone \\
AO & Aouinet Ouenine & Middle to Upper Devonian & Mudstone \\
D & D Sandstone Member & Lower Carboniferous & Sandstone \\
ED & Edjeleh & Middle Ordovician & Sandstone \\
F2 & F2 Sandstone Member & Upper Devonian & Sandstone \\
F3 & F3 Sandstone Member & Middle Devonian & Sandstone \\
F4-6 & F4 to F6 Sandstone & Lower Devonian & Sandstone \\
& Members & & Sandstone and \\
GL & Gara Louki & Upper Ordovician to & mudstone \\
HM & Hamra & Lower Silurian & Sandstone \\
HL & Hassi Leila & Lower Ordovician & Sandstone \\
TZ & Tanezzuft & Cambrian-Ordovician & Mudstone \\
\hline
\end{tabular}


Table 2. Reservoir properties of discovered accumulations for the Tanezzuft-Illizi Structural/Stratigraphic Assessment Unit through 1995. [nd, represents either no data or insufficient data. Data from Petroconsultants (1996a)]

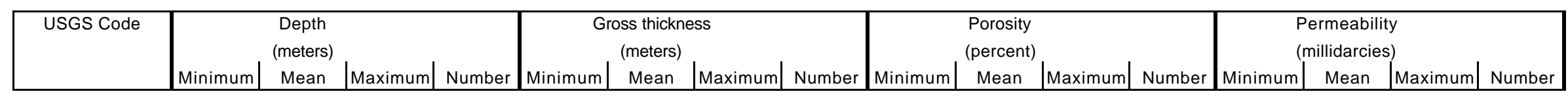

205601 Tanezzuft-llizi Total Petroleum System

$20560101 \quad$ Tanezzuft-Illizi Structural/Stratigraphic Assessment Unit

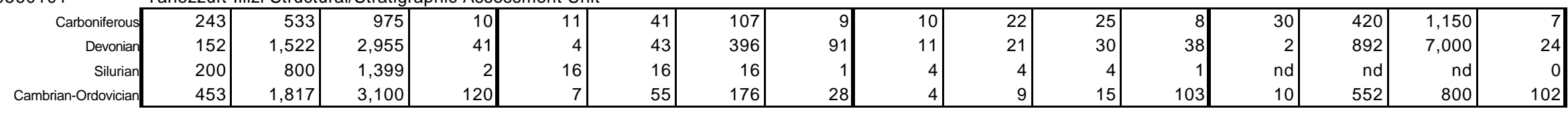


Table 3. Number and sizes of discovered fields for the Tanezzuft-Illizi Structural/Stratigraphic Assessment Unit through 1995. [M M B O, million barrels of oil; BCFG, billion cubic feet of gas; NGL, natural gas liquids; M M B NGL, million barrels of NGL. Volumes reported are summed for oil and gas fields (USGS defined). Oil and gas fields containing known volumes below 1 million barrels of oil or 6 billion cubic feet of gas (BCFG) are grouped. Data from Petroconsultants (1996a)]

\begin{tabular}{|c|c|c|c|c|}
\hline USGS Code & $\begin{array}{c}\text { Number of } \\
\text { fields }\end{array}$ & Known (discovered) volumes \\
& & Oil (MMBO) & Gas (BCFG) & NGL (MMBNGL) \\
\hline
\end{tabular}

\begin{tabular}{|c|c|c|c|c|}
\hline 205601 & \multicolumn{4}{|c|}{ Tanezzuft-IIlizi Total Petroleum System } \\
\hline 20560101 & Tanezzuft-Illiz & ctural/S & raphic $A$ & Jnit \\
\hline Oil fields & 51 & 3,406 & 14,795 & 263 \\
\hline Gas fields & 38 & 262 & 30,244 & 635 \\
\hline Fields $<1 \mathrm{MMBOE}$ & 13 & 2 & 22 & 0 \\
\hline All fields & 102 & 3,670 & 45,061 & 898 \\
\hline
\end{tabular}

\begin{tabular}{r|r|r|r|r|}
2056 & Total \\
\cline { 3 - 6 } Oil fields & 51 & 3,406 & 14,795 & 263 \\
Gas fields & 38 & 262 & 30,244 & 635 \\
Fields < 1 MMBOE & 13 & 2 & 22 & 0 \\
& & & & \\
All fields & 102 & 3,670 & 45,061 & 898 \\
\cline { 3 - 5 } & &
\end{tabular}


Table 4. Estimated sizes, number, and coproduct ratios of undiscovered oil and gas fields for the Tanezzuft-Illizi Structural/Stratigraphic Assessment Unit. [M M BO, million barrels of oil; BCFG, billion cubic feet of gas; CFG/B 0, cubic feet of gas per barrel oil, not calculated for gas fields; B NGL/M M CFG or BL/M M CFG, barrels of natural gas liquids or barrels of total liquids per million cubic feet of gas. BNGL/M M CFG was calculated for USGS-defined oil fields whereas BL/M M CFG was calculated for USGS-defined gas fields. Shifted mean, the mean size of the accumulation within a lognormal distribution of field sizes for which the origin is the selected minimum field size ]

\begin{tabular}{|c|c|c|c|c|c|c|c|c|c|c|c|c|c|c|c|c|c|}
\hline \multirow[t]{2}{*}{$\begin{array}{l}\text { USGS } \\
\text { Code }\end{array}$} & \multicolumn{4}{|c|}{$\begin{array}{l}\text { Size of accumulations } \\
\text { (MMBO or BCFG) }\end{array}$} & \multicolumn{4}{|c|}{ Number of accumulations } & \multicolumn{5}{|c|}{$\begin{array}{l}\text { Gas-to-oil ratio } \\
\text { (CFG/BO) }\end{array}$} & \multicolumn{4}{|c|}{$\begin{array}{l}\text { NGL-to-gas ratio } \\
\text { (BNGL/MMCFG) }\end{array}$} \\
\hline & Minimum & Median |Maximum| & Mean & Shifted mean & Minimum & Median |Maximum| & Mean & Mode & Minimum & Median & Maximum & Mean & Mode & Minimum & Median |Maximum| & Mean & Mode \\
\hline
\end{tabular}

205601 Tanezzuft-Illizi Total Petroleum System

20560101 Tanezzuft-Illizi Structural/Stratigraphic Assessment Unit

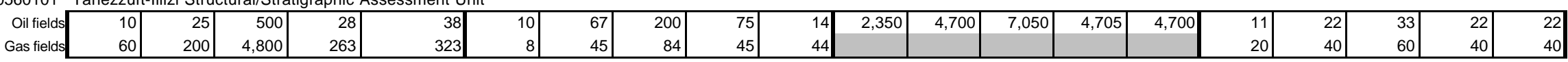


Table 5. Estimated undiscovered conventional oil, gas, and natural gas liquids volumes for oil and gas fields for the Tanezzuft-Illizi Structural/Stratigraphic Assessment Unit. [M M BO, million barrels of oil; BCFG, billion cubic feet of gas; NGL, natural gas liquids; M M BNGL, million barrels of natural gas liquids. Volumes of undisc overed NGL were calculated for oil fields whereas volumes of total liquids (oil plus NGL) were calculated for USGS-defined gas fields. Largest anticipated undiscovered field is in units of M M BO for oil fields and BCFG for gas fields. Results shown are estimates that are fully risked with respect to geology and accessibility. Undiscovered volumes in fields smaller than the selected minimum field size are excluded from the assessment. M eans can be summed, but fractiles (F95, F50, and F5) can be summed only if a correlation coefficient of +1.0 is assumed]

\begin{tabular}{|c|c|c|c|c|c|c|c|c|c|c|c|c|c|c|c|c|c|c|}
\hline \multirow[t]{3}{*}{$\begin{array}{l}\text { USGS } \\
\text { Code }\end{array}$} & \multirow[t]{3}{*}{ MFS } & \multirow{3}{*}{$\begin{array}{r}\text { Prob. } \\
(0-1)\end{array}$} & \multicolumn{12}{|c|}{ Undiscovered conventional volumes } & \multirow{2}{*}{\multicolumn{4}{|c|}{$\begin{array}{l}\text { Largest anticipated undiscovered field } \\
\text { (MMBO or BCFG) }\end{array}$}} \\
\hline & & & \multicolumn{4}{|c|}{ Oil (MMBO) } & \multicolumn{4}{|c|}{ Gas (BCFG) } & \multicolumn{4}{|c|}{ NGL (MMBNGL) } & & & & \\
\hline & & & F95 & F50 & F5 & Mean & F95 & F50 & F5 & Mean & F95 & F50 & F5 & Mean & F95 & F50 & F5 & Mean \\
\hline
\end{tabular}

205601 Tanezzuft-Illizi Total Petroleum System

20560101 Tanezzuft-Illizi Structural/Stratigraphic Assessment Unit

\begin{tabular}{|c|c|c|c|c|c|c|c|c|c|c|c|c|c|c|c|c|c|c|}
\hline Oil fields & 10 & 1.00 & 601 & 2,520 & 6,000 & 2,814 & 2,655 & 11,444 & 29,734 & 13,235 & 55 & 244 & 685 & 291 & 86 & 205 & 419 & 222 \\
\hline Gas fields & 60 & 1.00 & & & & & 5,809 & 14,241 & 24,286 & 14,550 & 213 & 551 & 1,055 & 582 & 753 & 1,633 & 3,696 & 1,842 \\
\hline All fields & & & 601 & 2,520 & 6,000 & 2,814 & 8,464 & 25,685 & 54,020 & 27,785 & 269 & 795 & 1,740 & 873 & & & & \\
\hline
\end{tabular}

2056

Total
\begin{tabular}{rl|r|r|r|r|r|r|r|r|r|r|r|r|} 
Oil fields \\
Gas fields
\end{tabular}




\section{APPENDIX}

Exploration-activity and discovery-history plots for each of the assessment units. Two sets of plots and statistics are provided, one set showing known field sizes (cumulative production plus remaining reserves) and another showing field sizes upon which a reserve-growth function was applied (labeled grown). Within each set of plots, oil fields and gas fields are treated separately. The plots include:

- $\quad$ Cumulative Number of New-Field Wildcat Wells vs. Drilling-Completion Year

- $\quad$ Number of New-Field Wildcat Wells vs. Drilling-Completion Year

- $\quad$ Oil- or Gas-Field Size (MMBO or BCFG) vs. Oil- or Gas-Field Rank by Size (With Respect to Discovery Halves or Thirds)

- $\quad$ Number of Oil or Gas Fields vs. Oil- or Gas-Field Size Classes (MMBO or BCFG) (With Respect to Discovery Halves or Thirds)

- Volume of Oil or Gas (MMBO or BCFG) vs. Oil- or Gas-Field Size Classes (MMBO or BCFG)

- $\quad$ Oil- or Gas-Field Size (MMBO or BCFG) vs. Field-Discovery Year

- $\quad$ Oil- or Gas-Field Size (MMBO or BCFG) vs. Cumulative Number of New-Field Wildcat Wells

- $\quad$ Cumulative Oil or Gas Volume (MMBO or BCFG) vs. Field-Discovery Year

- Cumulative Oil or Gas Volume (MMBO or BCFG) vs. Cumulative Number of NewField Wildcat Wells

- $\quad$ Cumulative Number of Oil or Gas Fields vs. Field-Discovery Year 
- $\quad$ Cumulative Number of Oil or Gas Fields vs. Cumulative Number of New-Field Wildcat Wells

- $\quad$ Reservoir Depth, Oil or Gas Fields (m) vs. Field-Discovery Year

- $\quad$ Reservoir Depth, Oil or Gas Fields (m) vs. Cumulative Number of New-Field Wildcat Wells

- $\quad$ Gas/Oil, Oil Fields (CFG/BO) vs. Mean Reservoir Depth (m)

- $\quad$ NGL/Gas, Oil Fields (BNGL/MMCFG) vs. Mean Reservoir Depth (m)

- $\quad$ Liquids/Gas, Gas Fields (BL/MMCFG) vs. Mean Reservoir Depth (m)

- $\quad$ Number of Reservoirs in Oil Fields vs. API Gravity (Degrees) 
Tanezzuft-IIlizi Structural/Stratigraphic, Assessment Unit 20560101

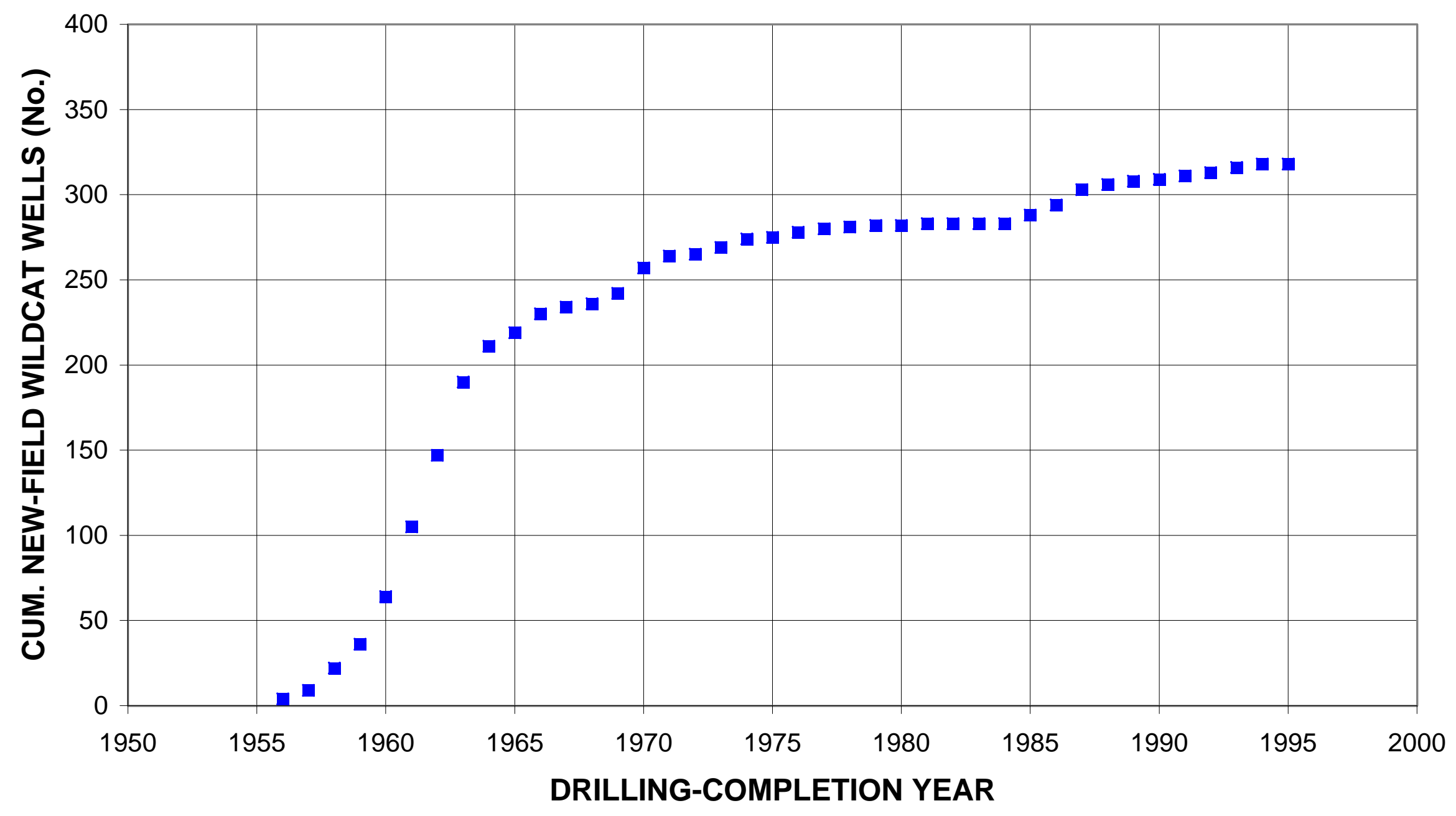


Tanezzuft-IIlizi Structural/Stratigraphic, Assessment Unit 20560101

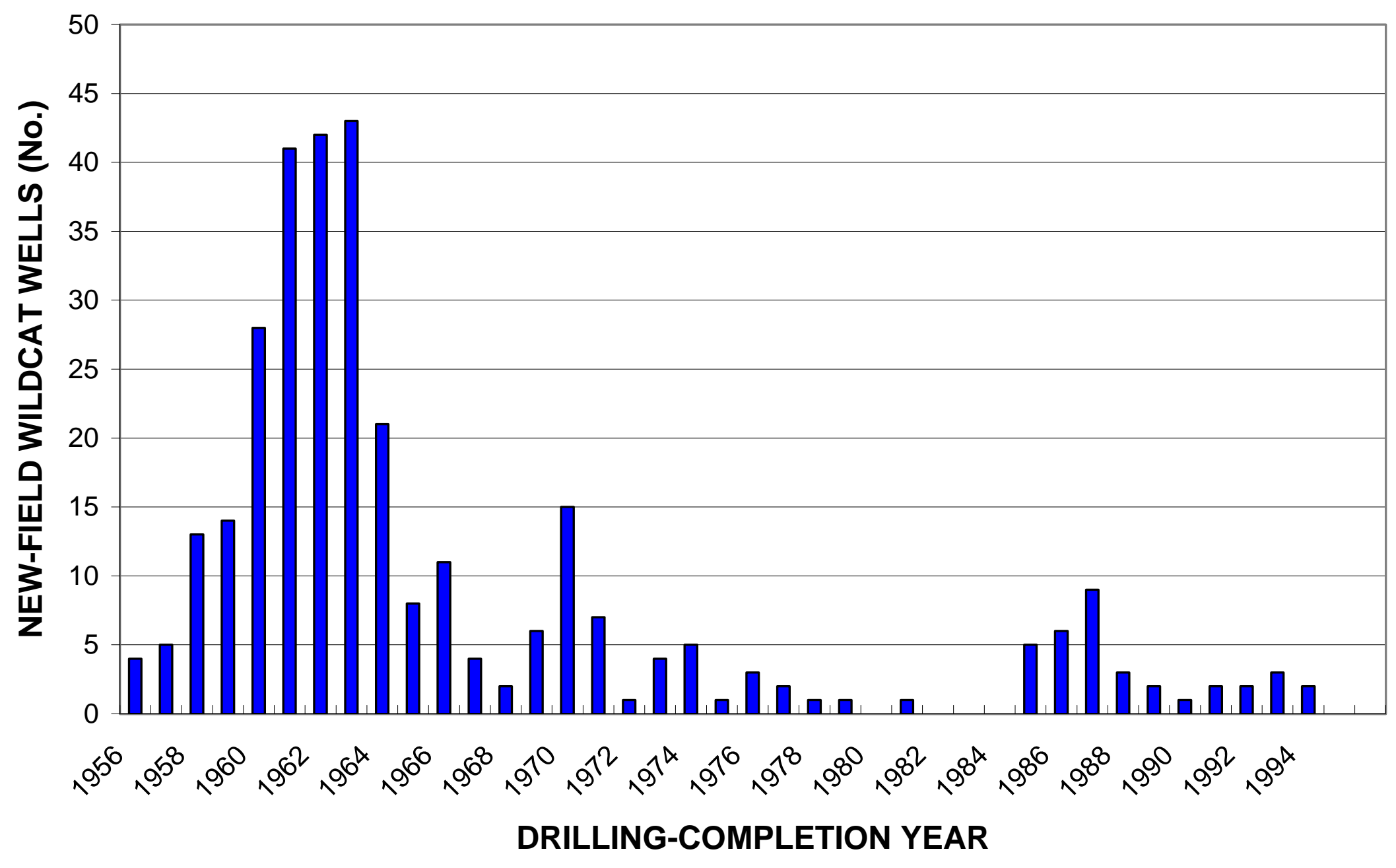




\section{Tanezzuft-Illizi Structural/Stratigraphic, Assessment Unit 20560101}

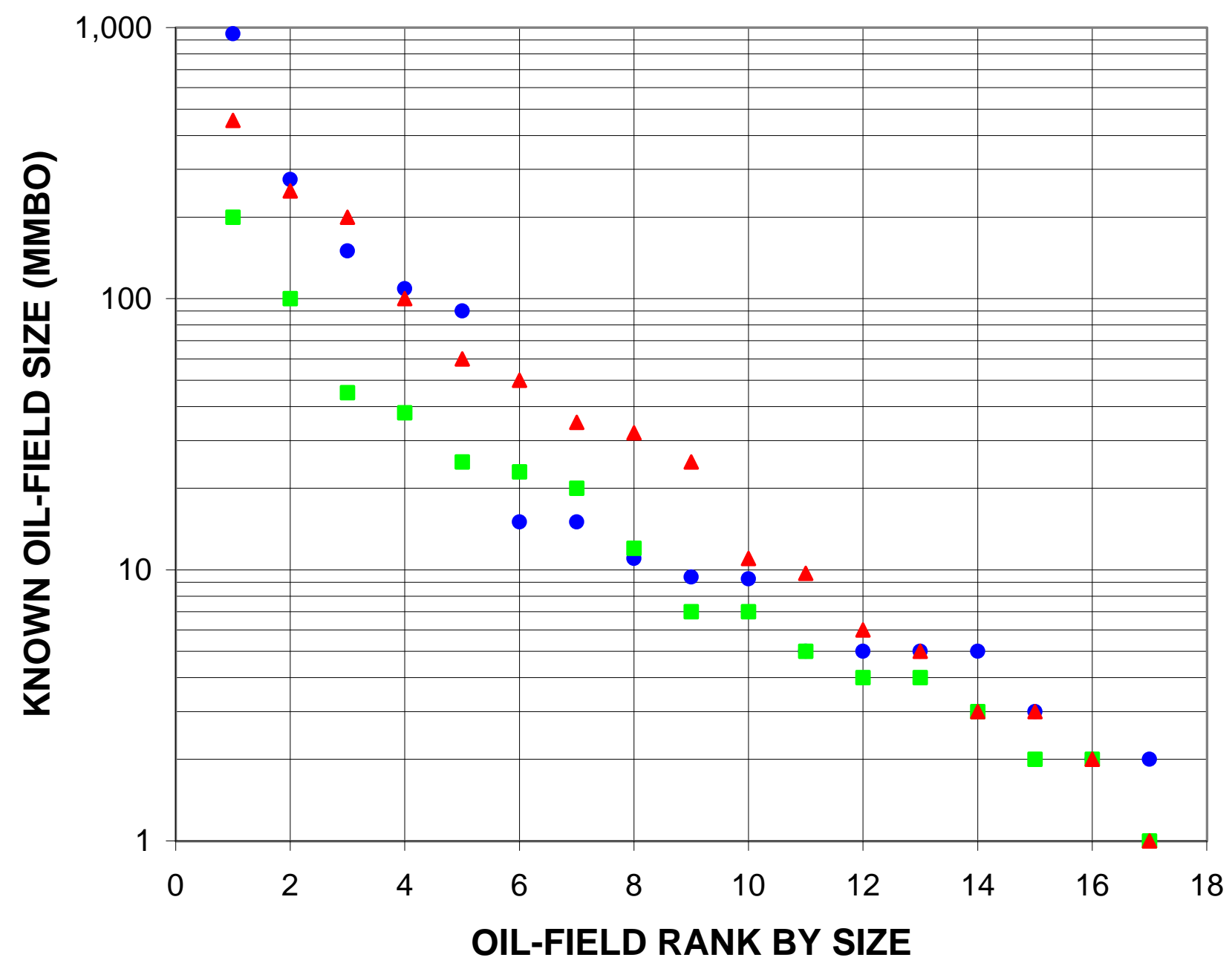

- First third of fields discovered

- Second third of fields discovered

$\Delta$ Third third of fields discovered 


\section{Tanezzuft-Illizi Structural/Stratigraphic, Assessment Unit}

20560101
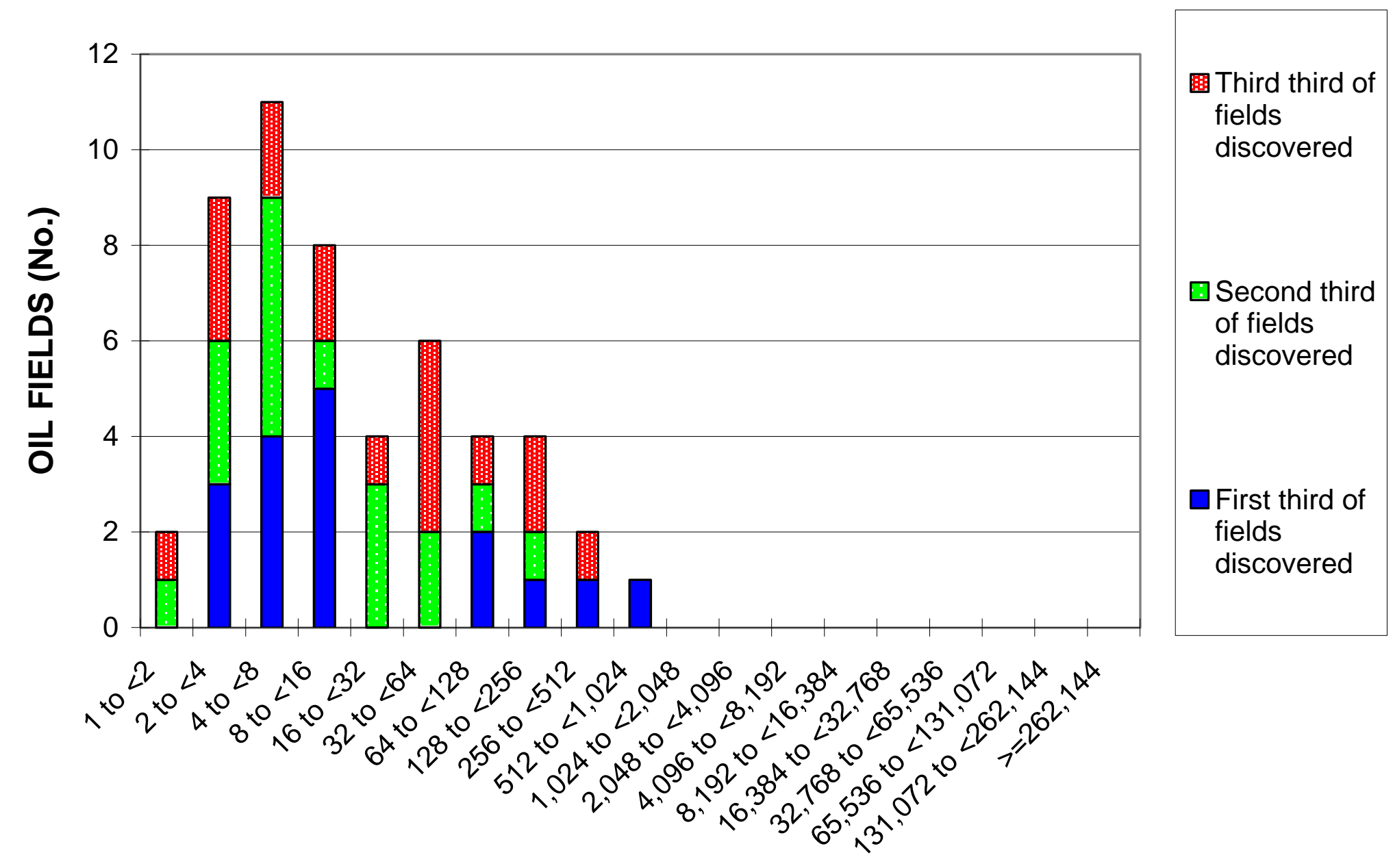

KNOWN OIL-FIELD SIZE (MMBO) 
Tanezzuft-Illizi Structural/Stratigraphic, Assessment Unit 20560101

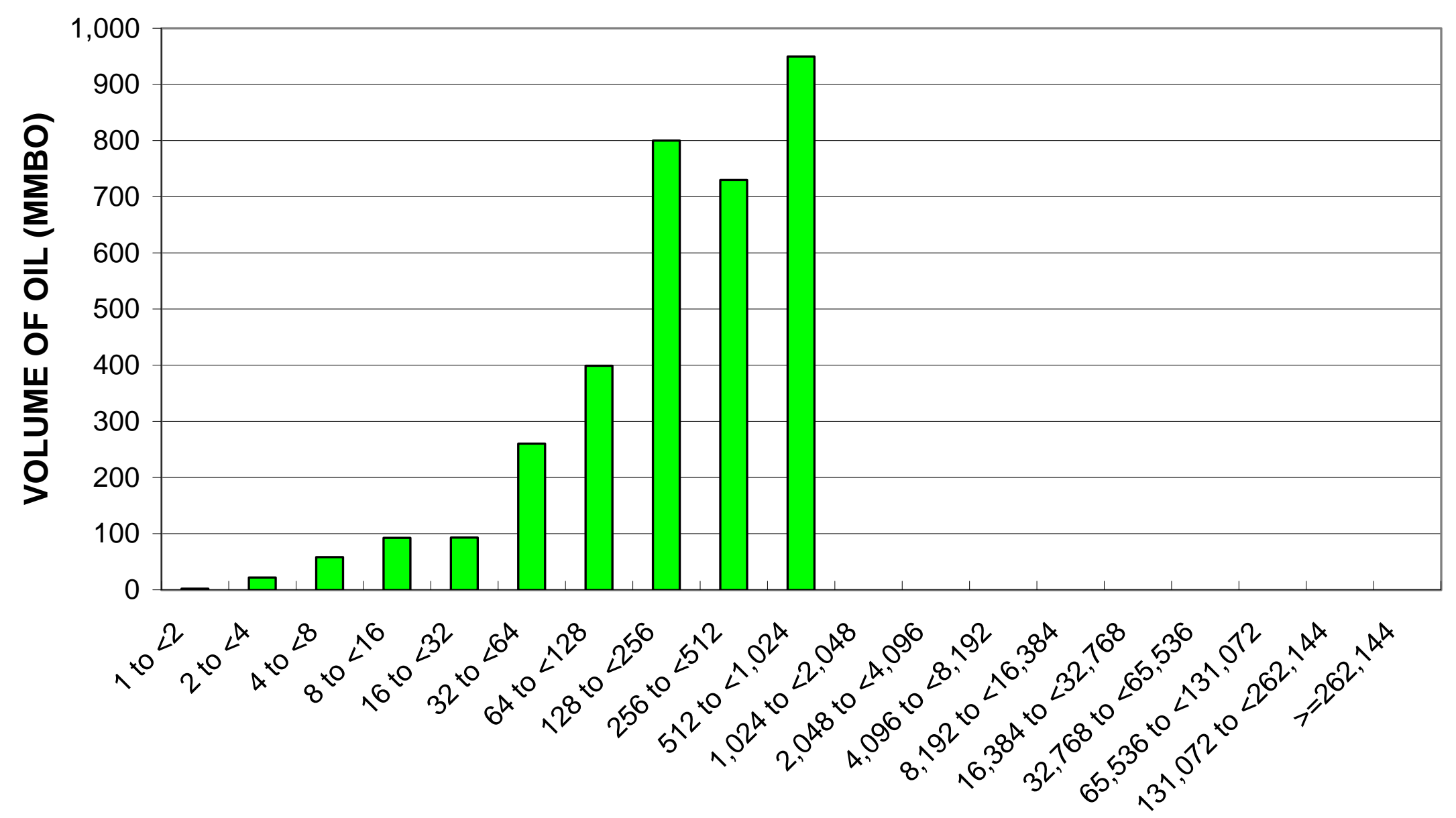

KNOWN OIL-FIELD SIZE (MMBO) 
Tanezzuft-IIlizi Structural/Stratigraphic, Assessment Unit 20560101

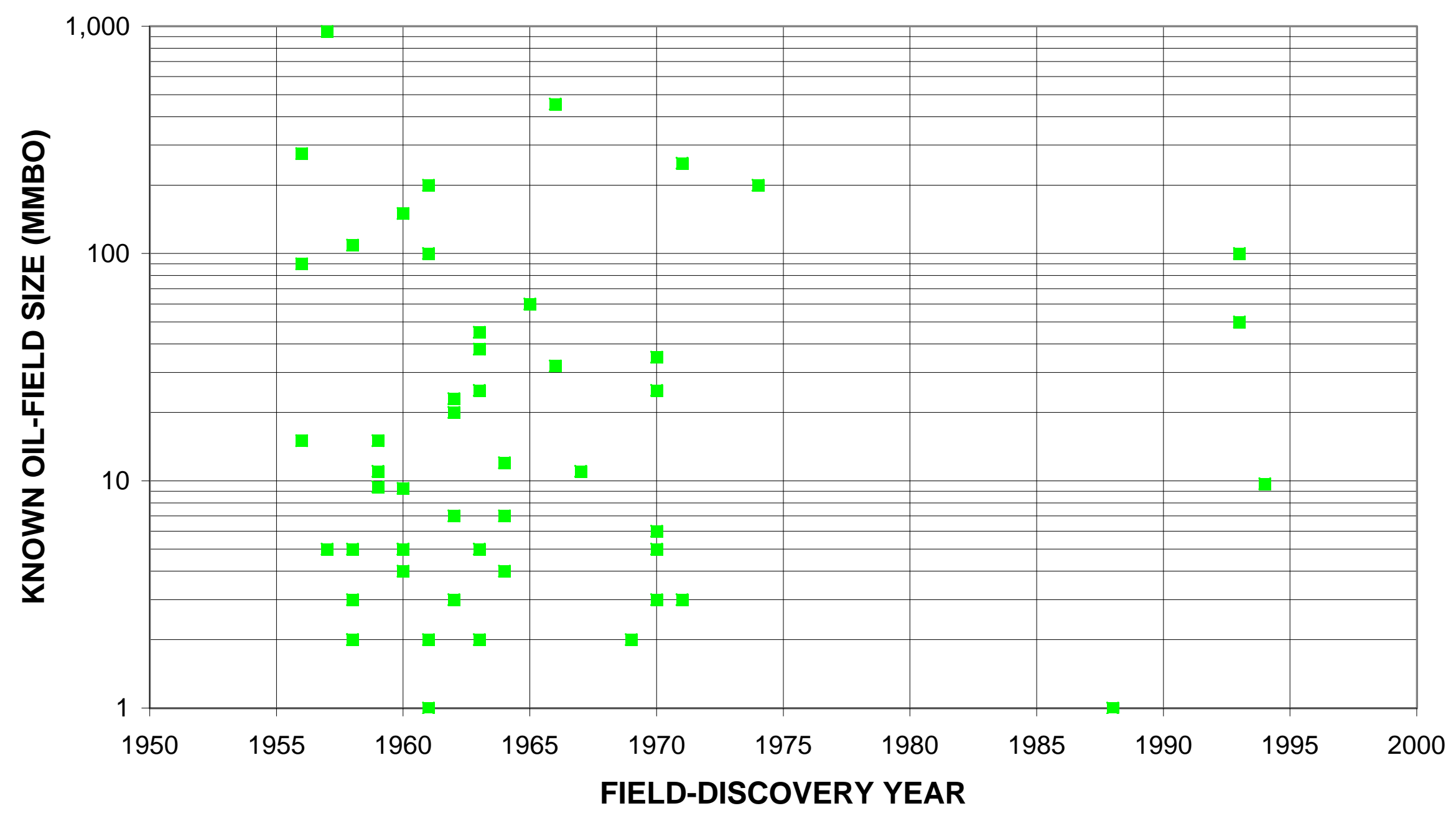




\section{Tanezzuft-Illizi Structural/Stratigraphic, Assessment Unit}

20560101

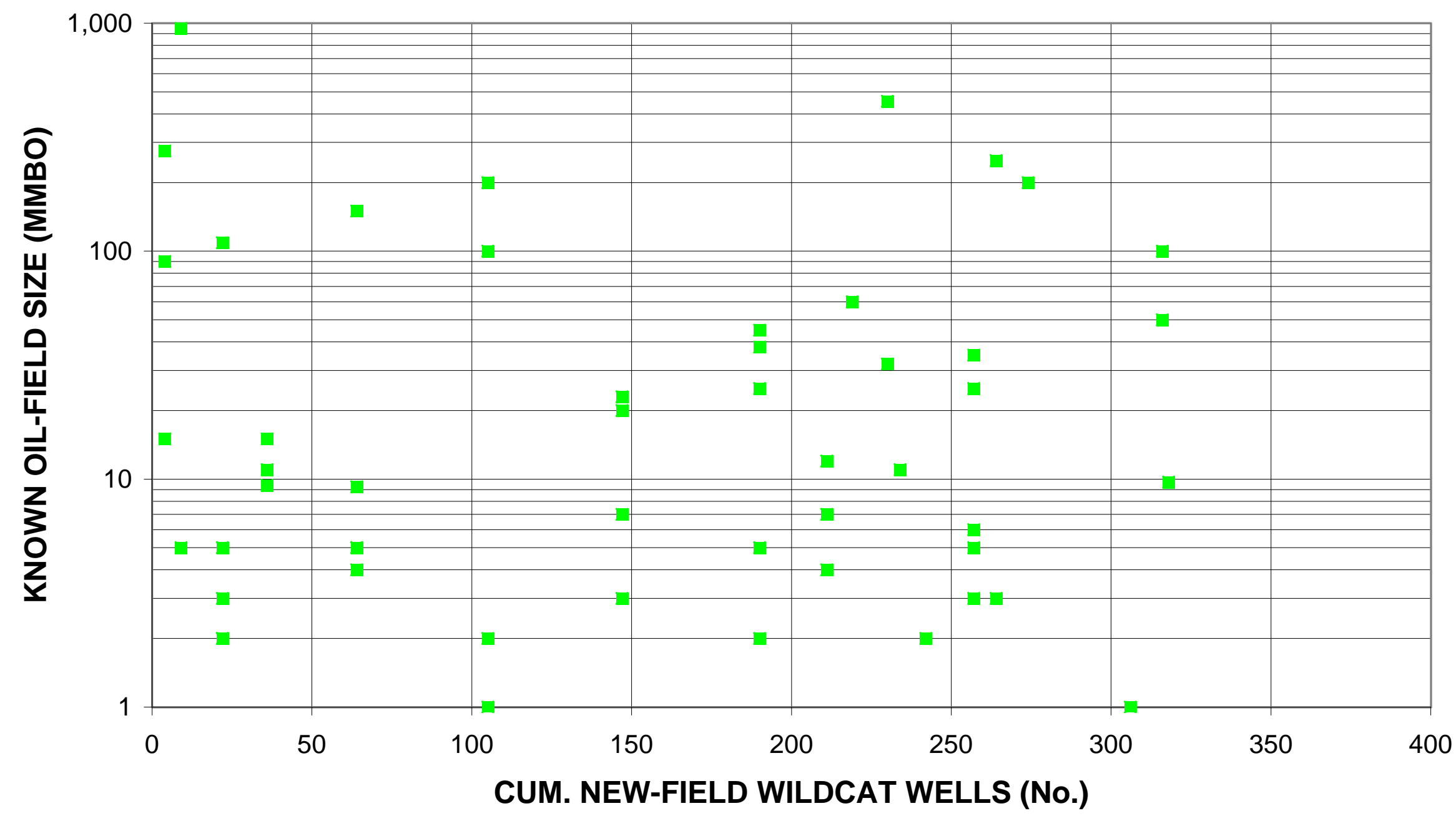


Tanezzuft-IIlizi Structural/Stratigraphic, Assessment Unit 20560101

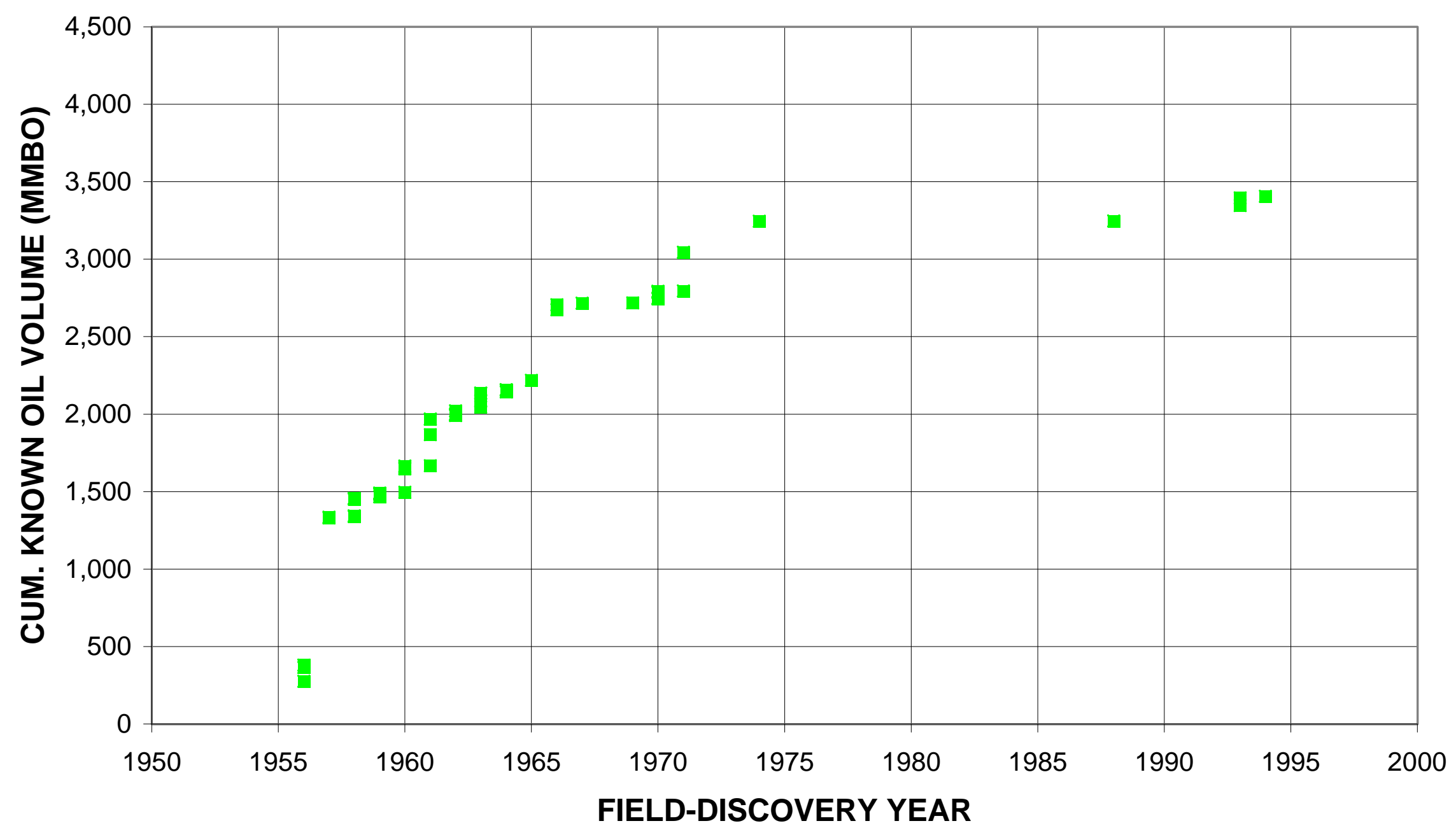


Tanezzuft-IIlizi Structural/Stratigraphic, Assessment Unit 20560101

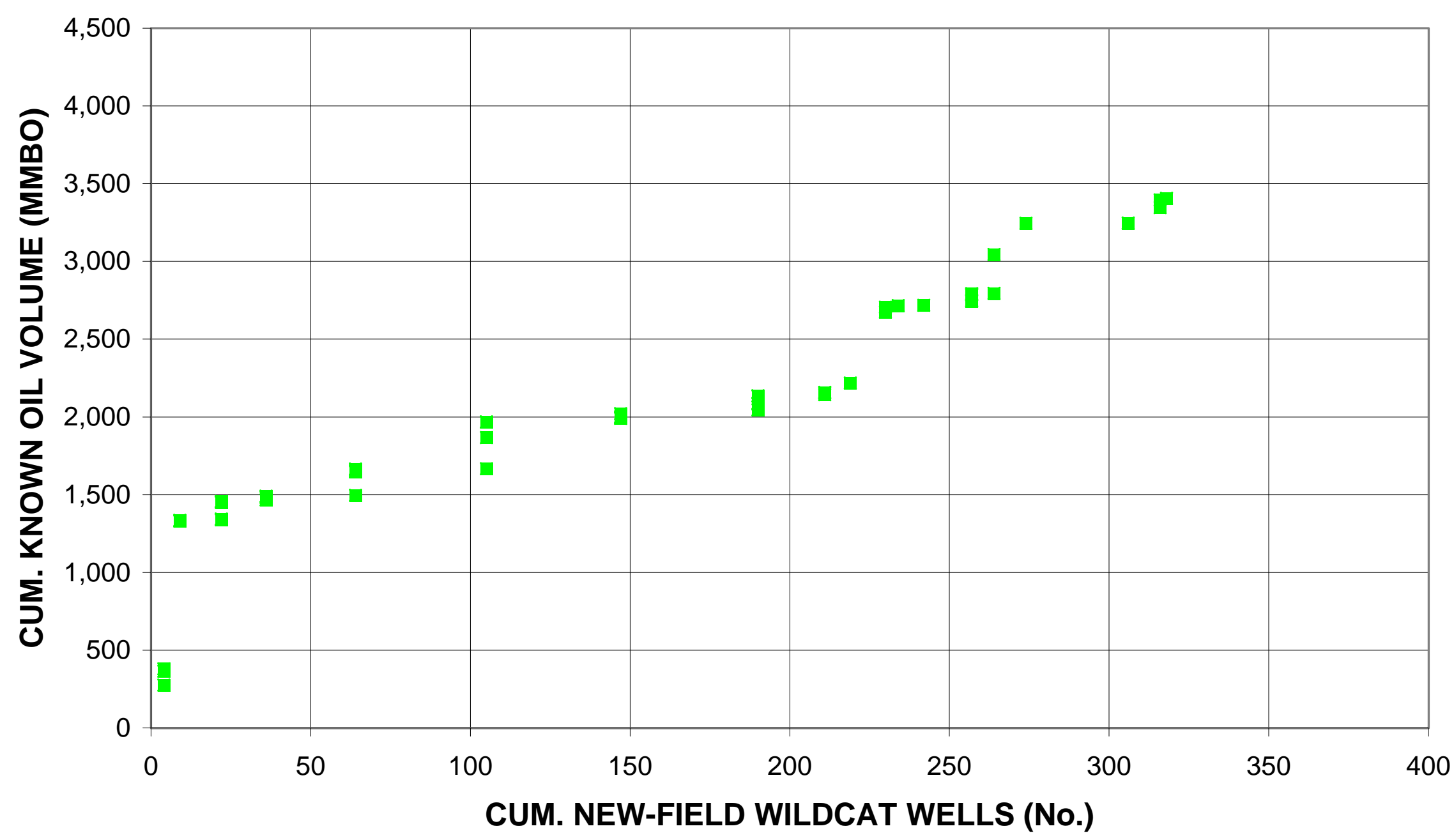


Tanezzuft-IIlizi Structural/Stratigraphic, Assessment Unit 20560101

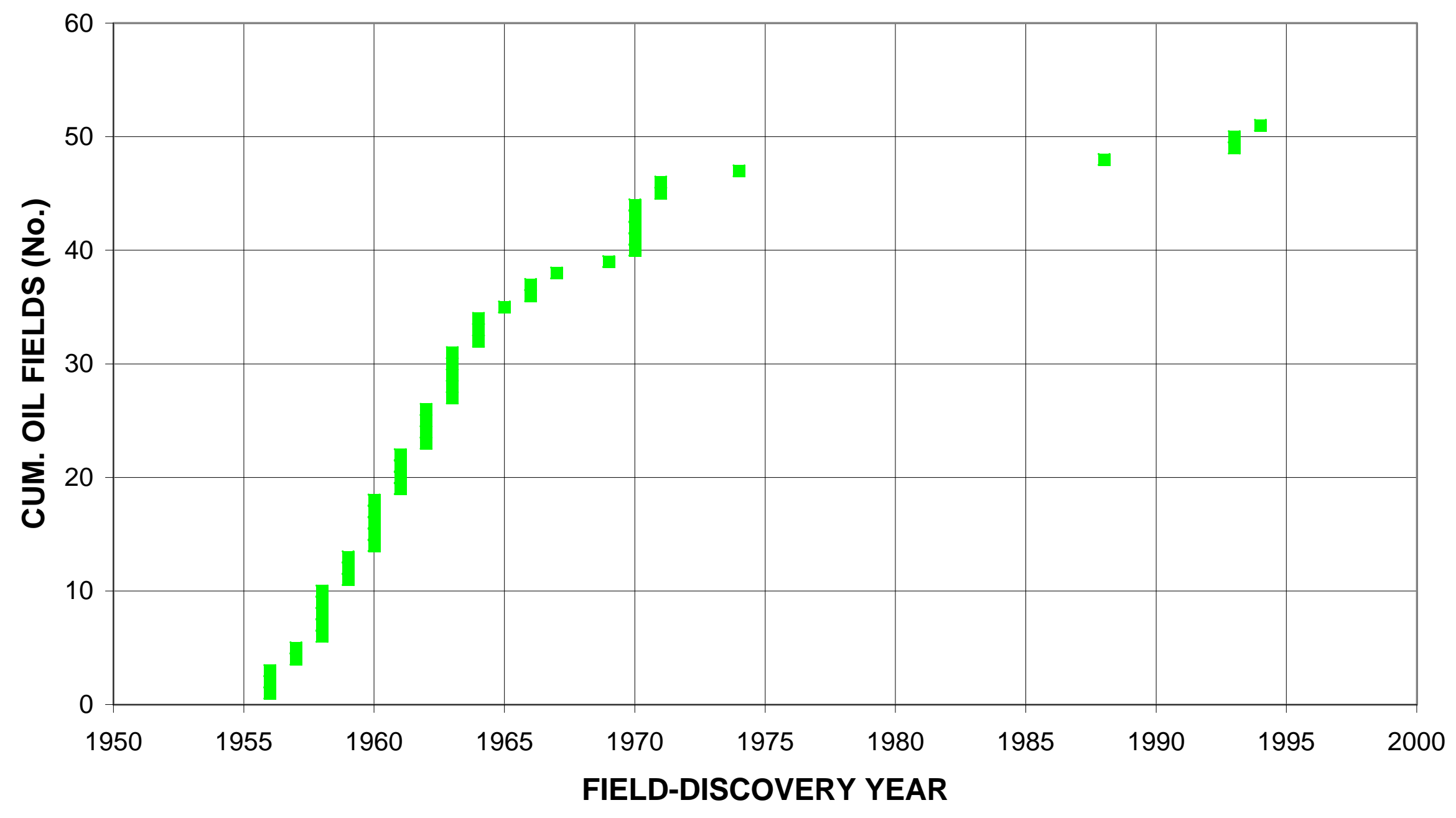


Tanezzuft-IIlizi Structural/Stratigraphic, Assessment Unit 20560101

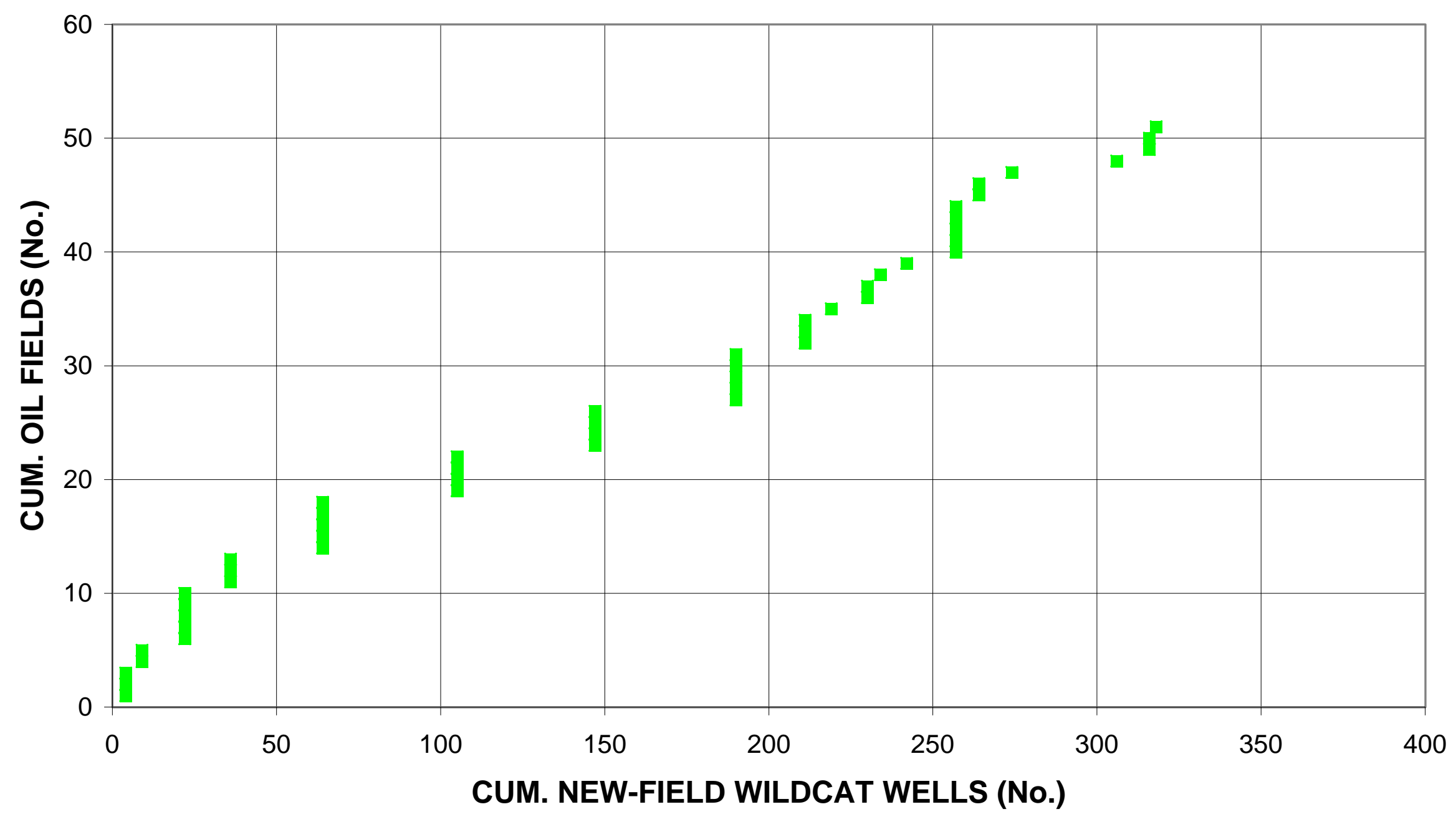


Tanezzuft-Illizi Structural/Stratigraphic, Assessment Unit 20560101

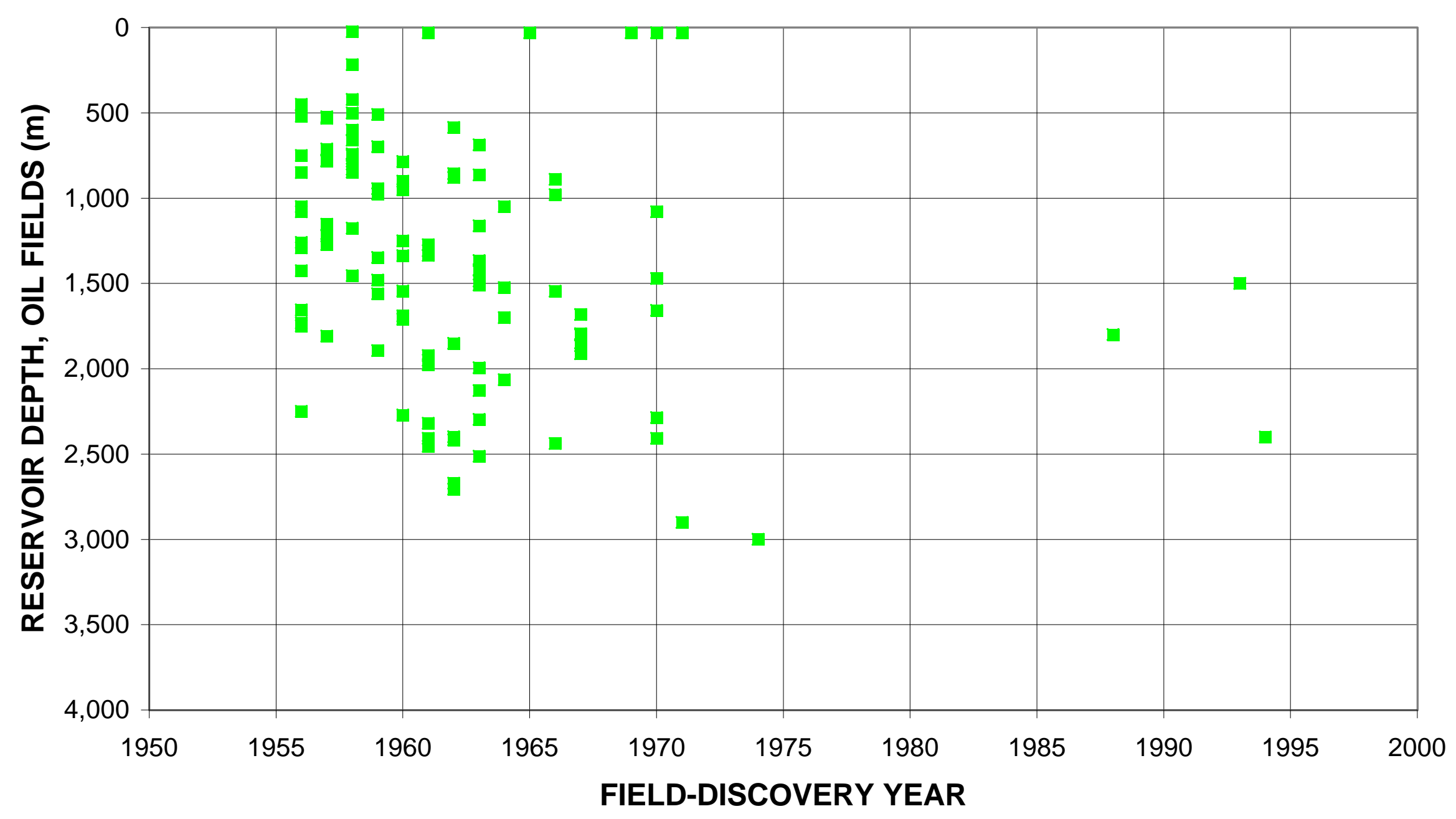


Tanezzuft-IIlizi Structural/Stratigraphic, Assessment Unit 20560101

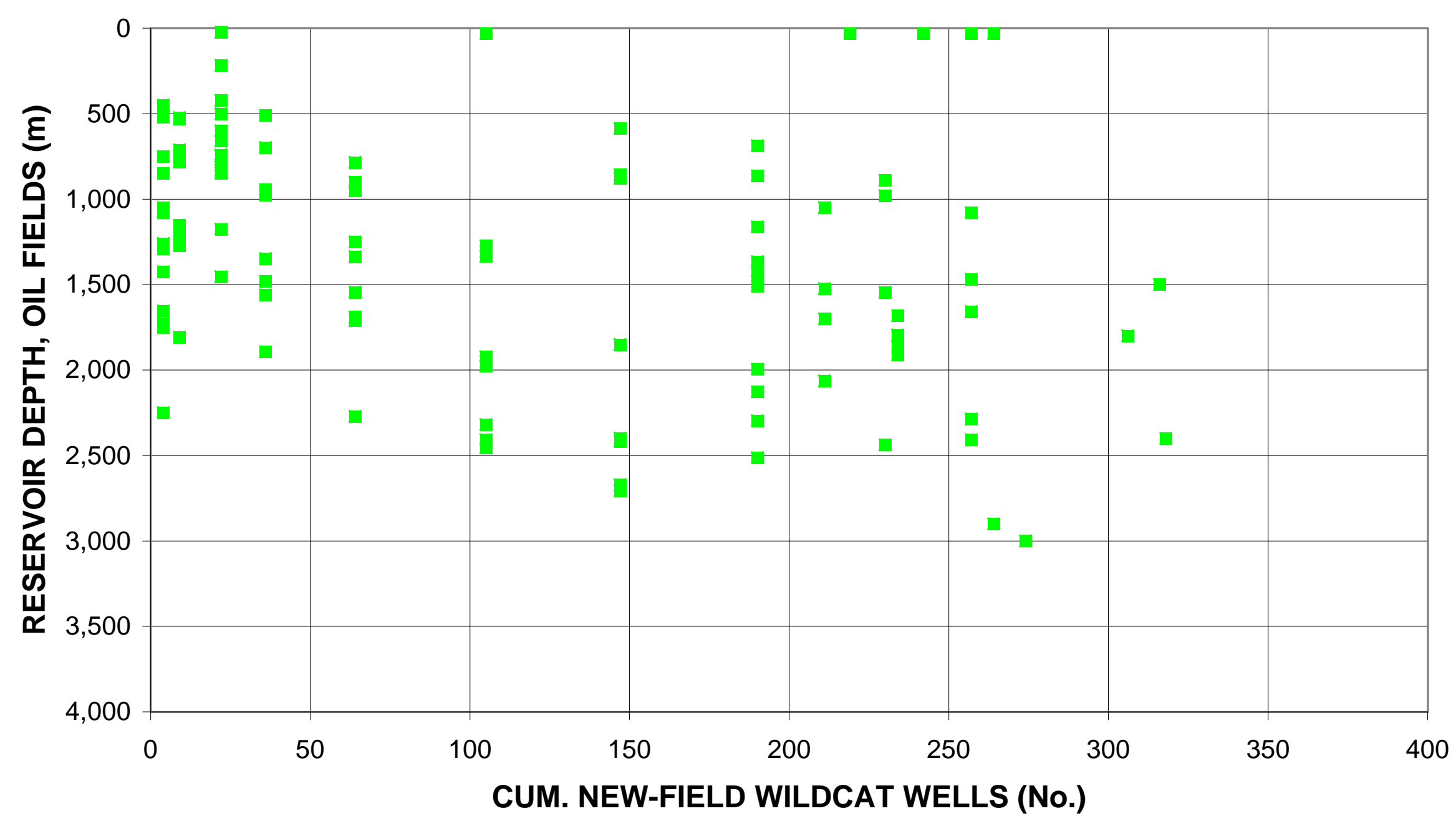


Tanezzuft-IIlizi Structural/Stratigraphic, Assessment Unit 20560101

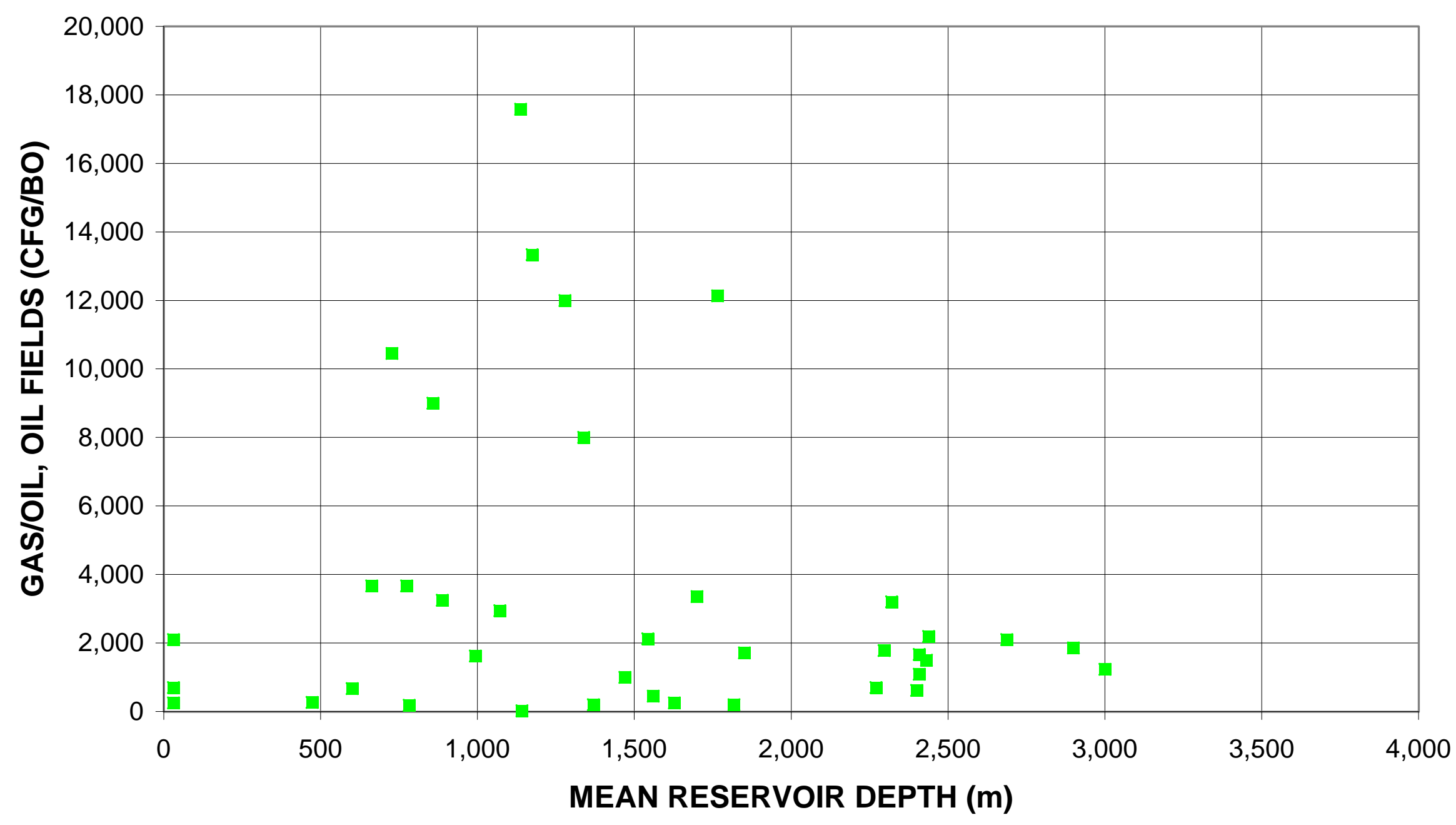


Tanezzuft-IIlizi Structural/Stratigraphic, Assessment Unit 20560101

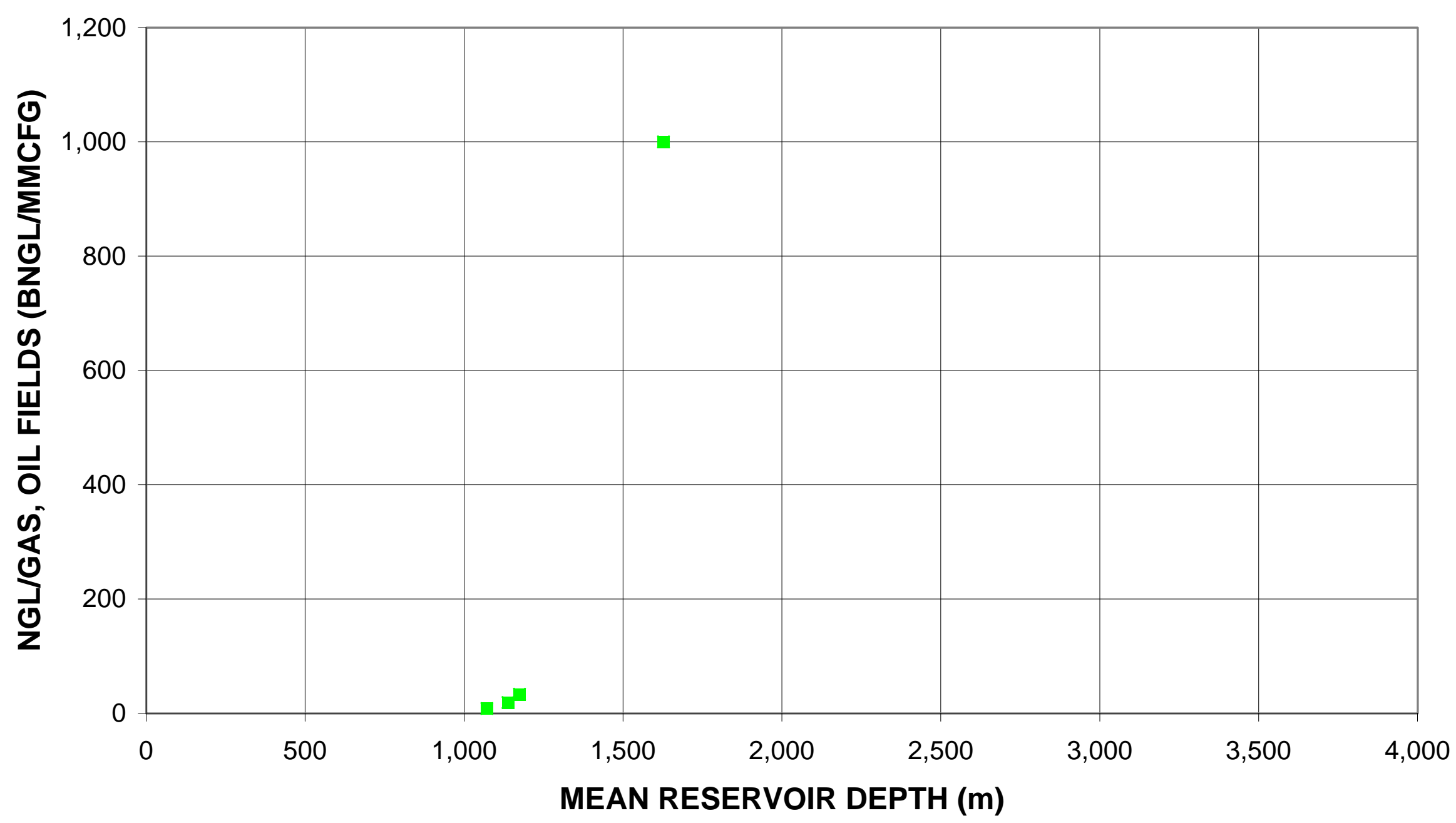


Tanezzuft-Illizi Structural/Stratigraphic, Assessment Unit 20560101

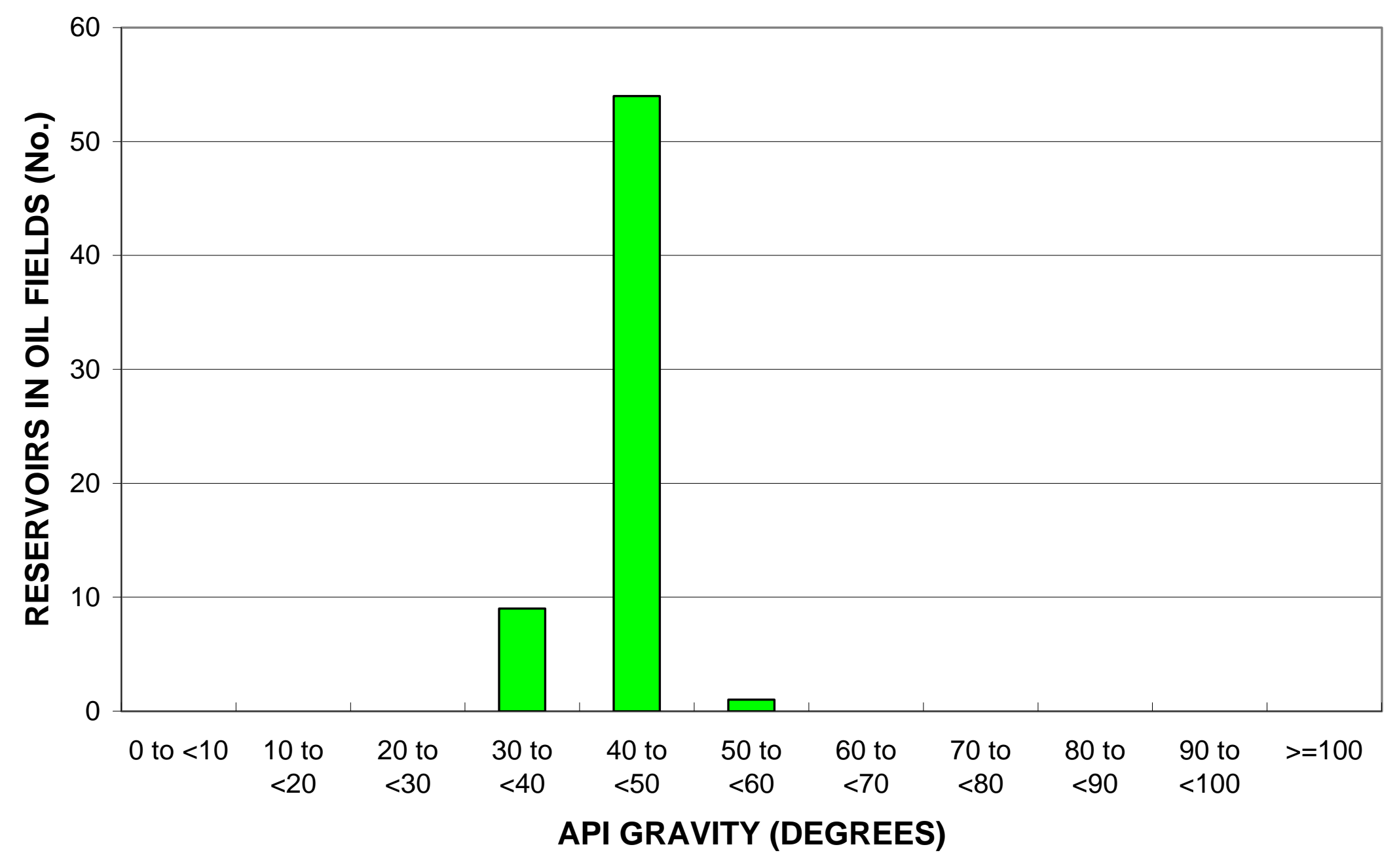




\section{Tanezzuft-Illizi Structural/Stratigraphic, Assessment Unit 20560101}

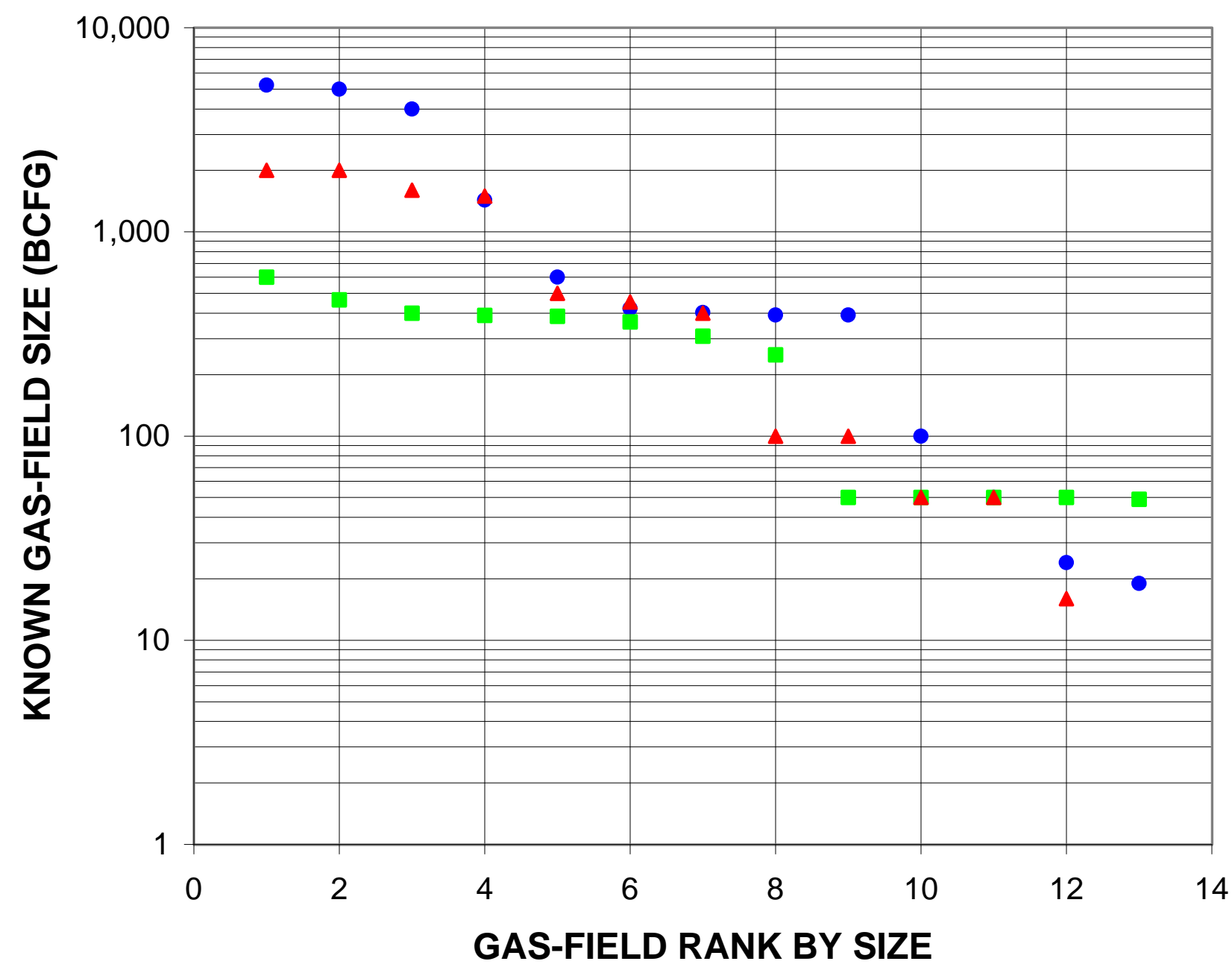

- First third of fields discovered

- Second third of fields discovered

$\Delta$ Third third of fields discovered 
Tanezzuft-Illizi Structural/Stratigraphic, Assessment Unit 20560101
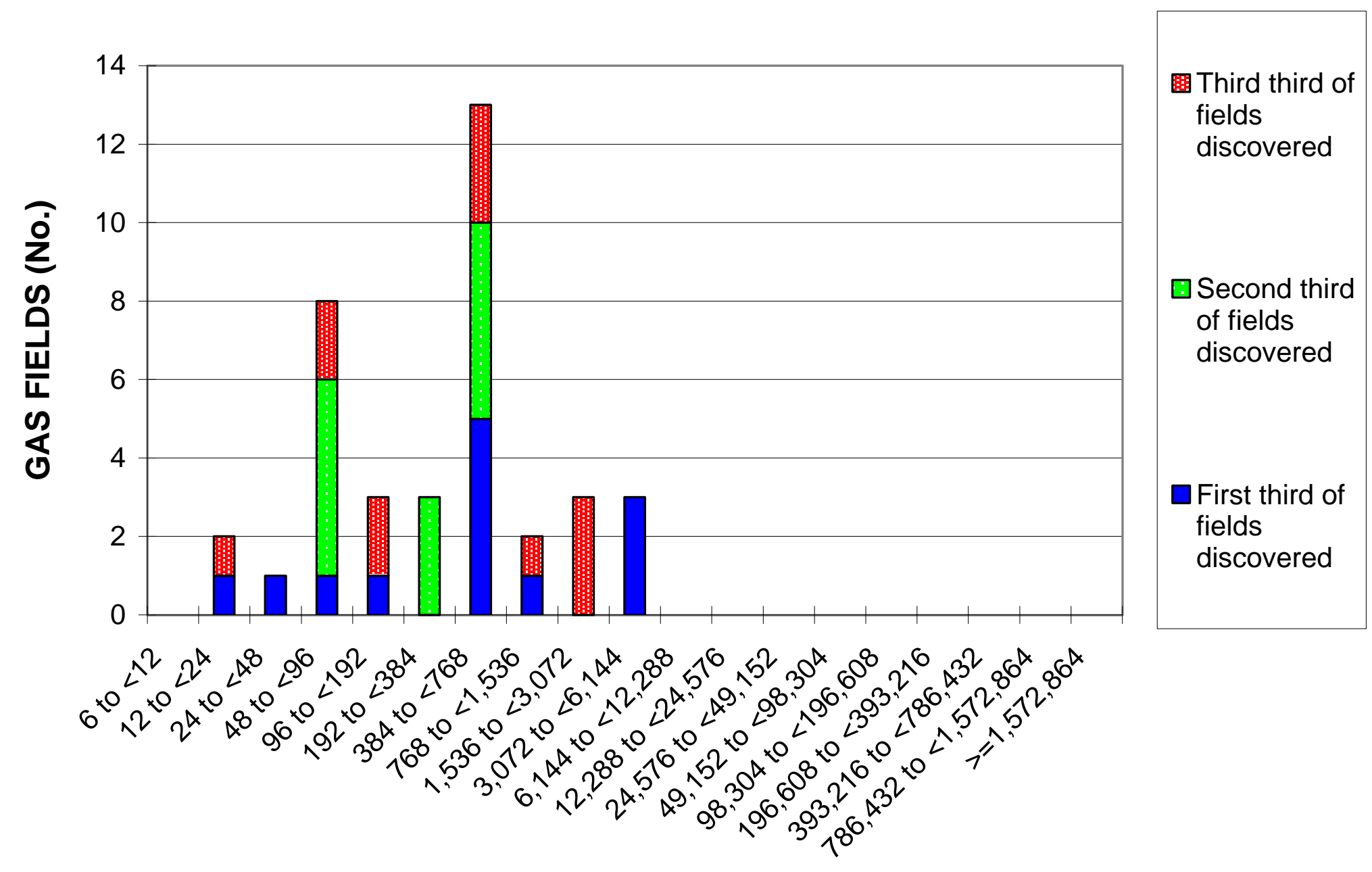

KNOWN GAS-FIELD SIZE (BCFG) 


\section{Tanezzuft-Illizi Structural/Stratigraphic, Assessment Unit}

20560101

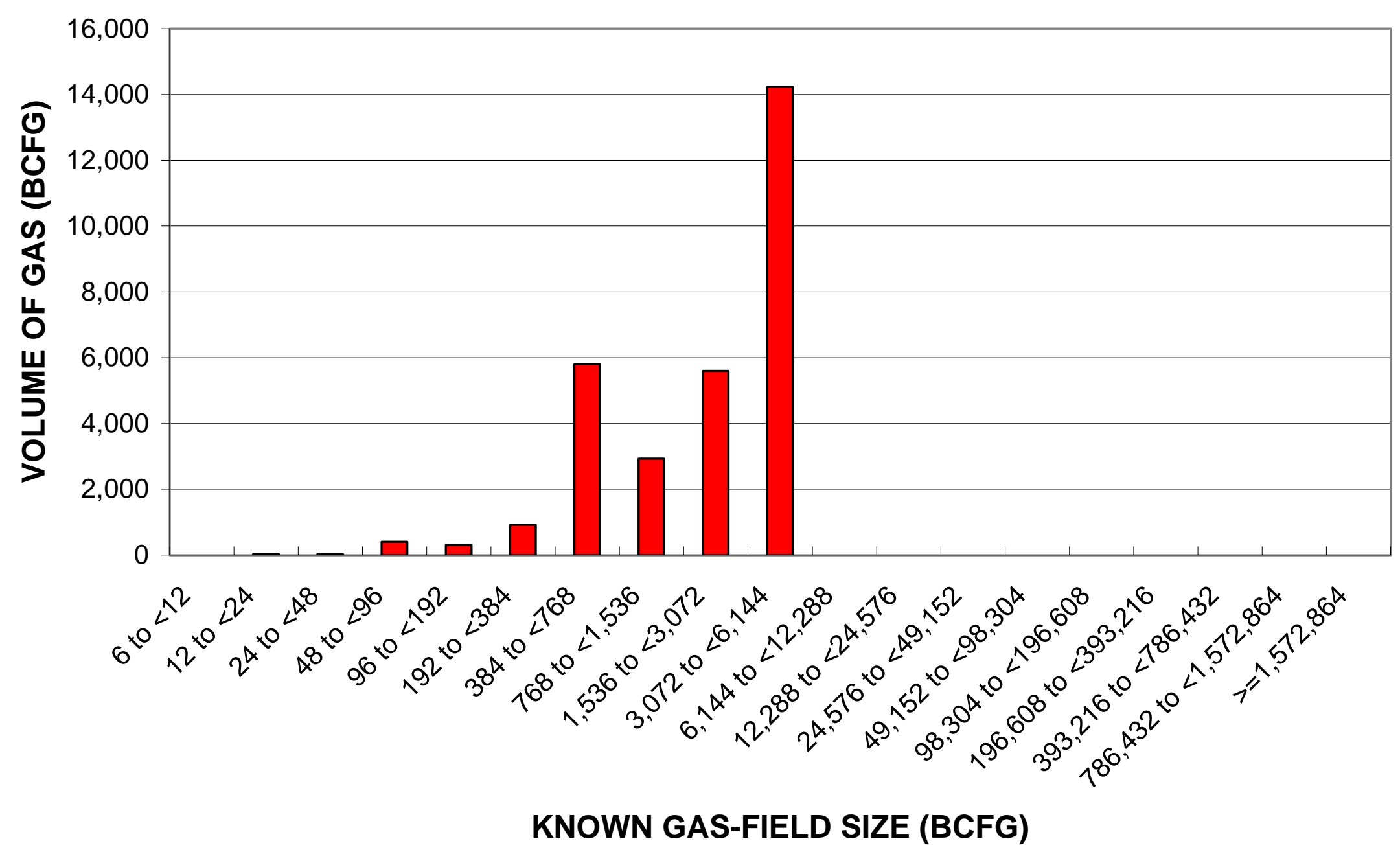


Tanezzuft-Illizi Structural/Stratigraphic, Assessment Unit 20560101

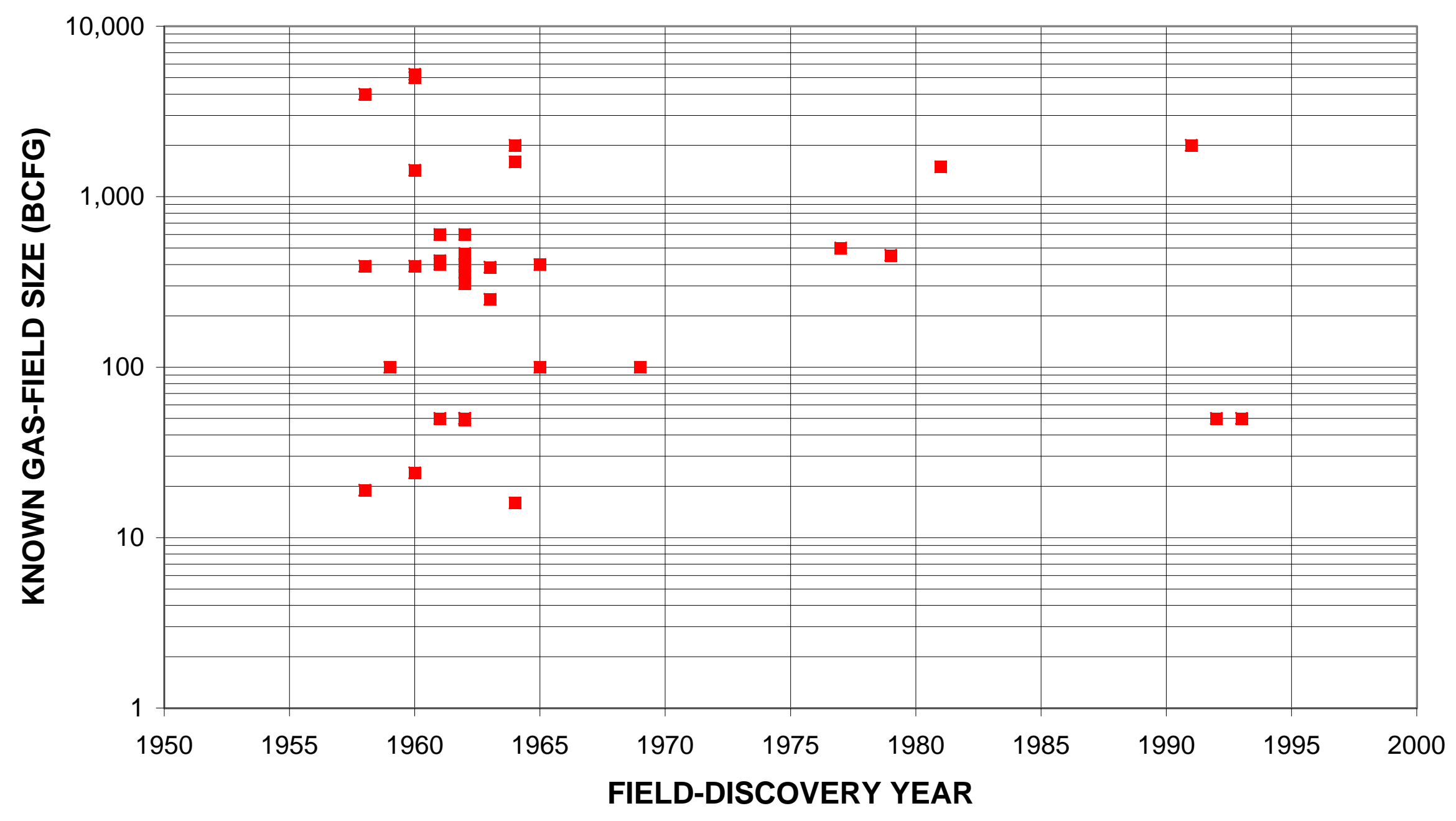


Tanezzuft-Illizi Structural/Stratigraphic, Assessment Unit 20560101

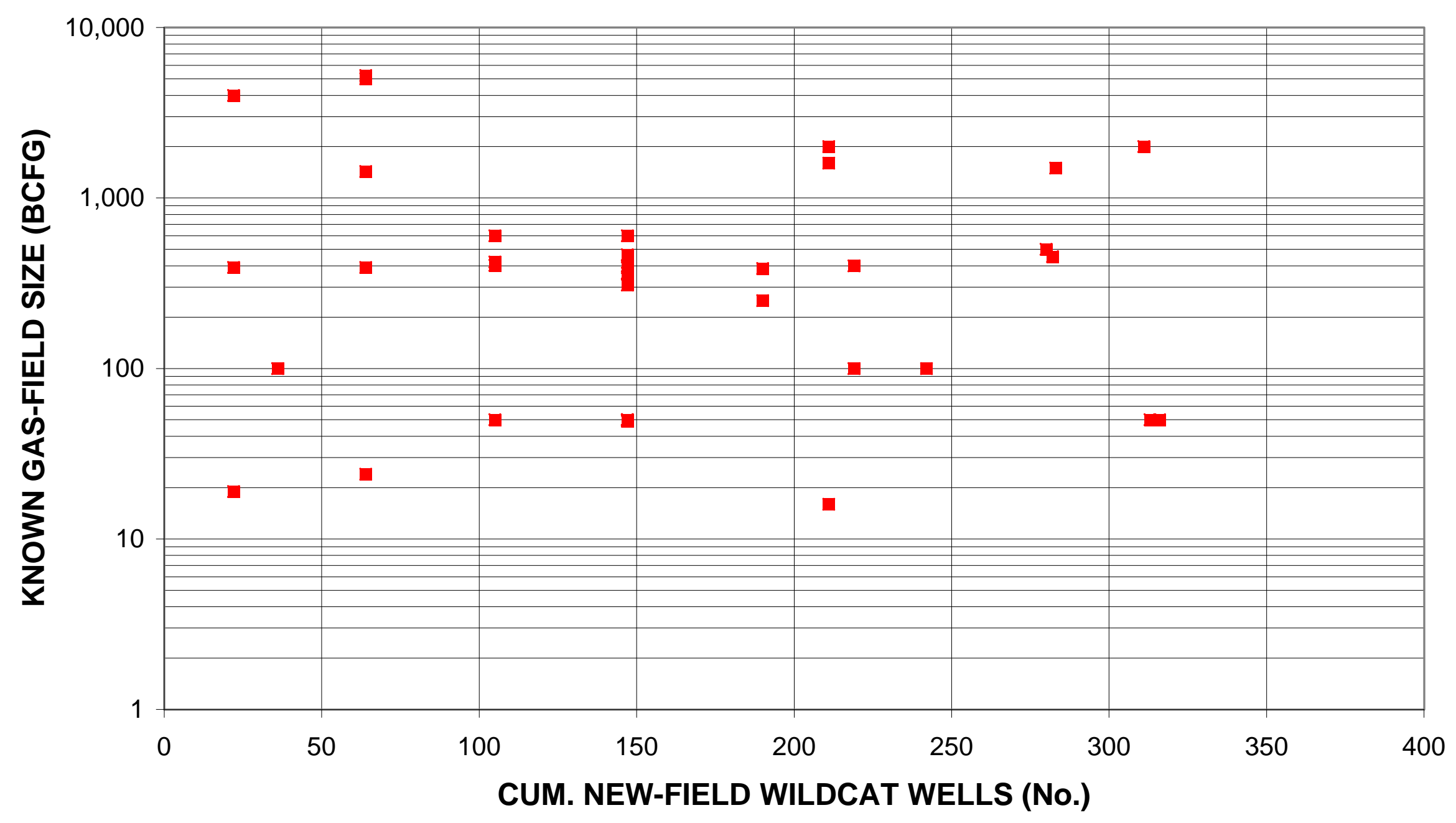


Tanezzuft-IIlizi Structural/Stratigraphic, Assessment Unit 20560101

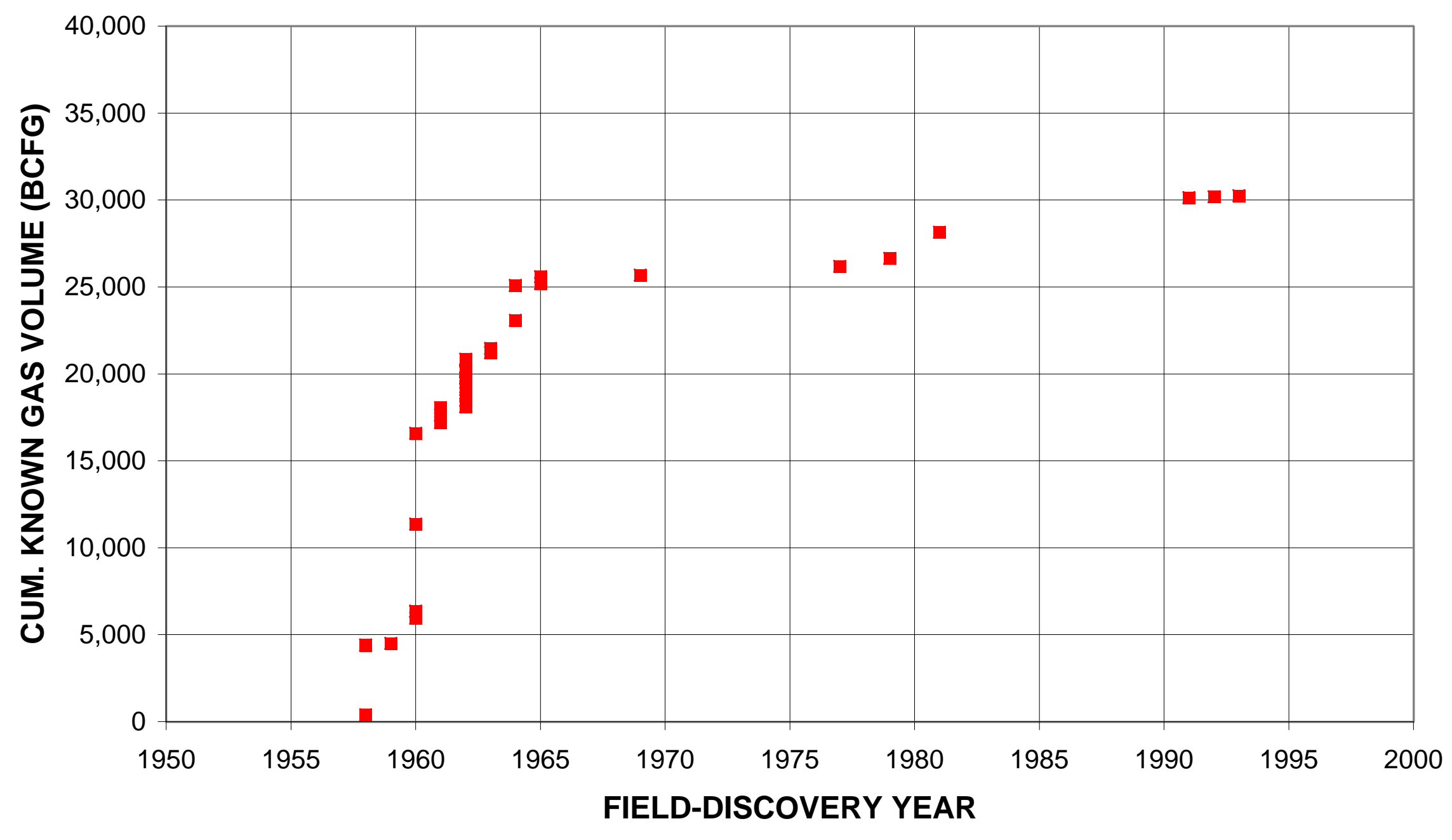


Tanezzuft-IIlizi Structural/Stratigraphic, Assessment Unit 20560101

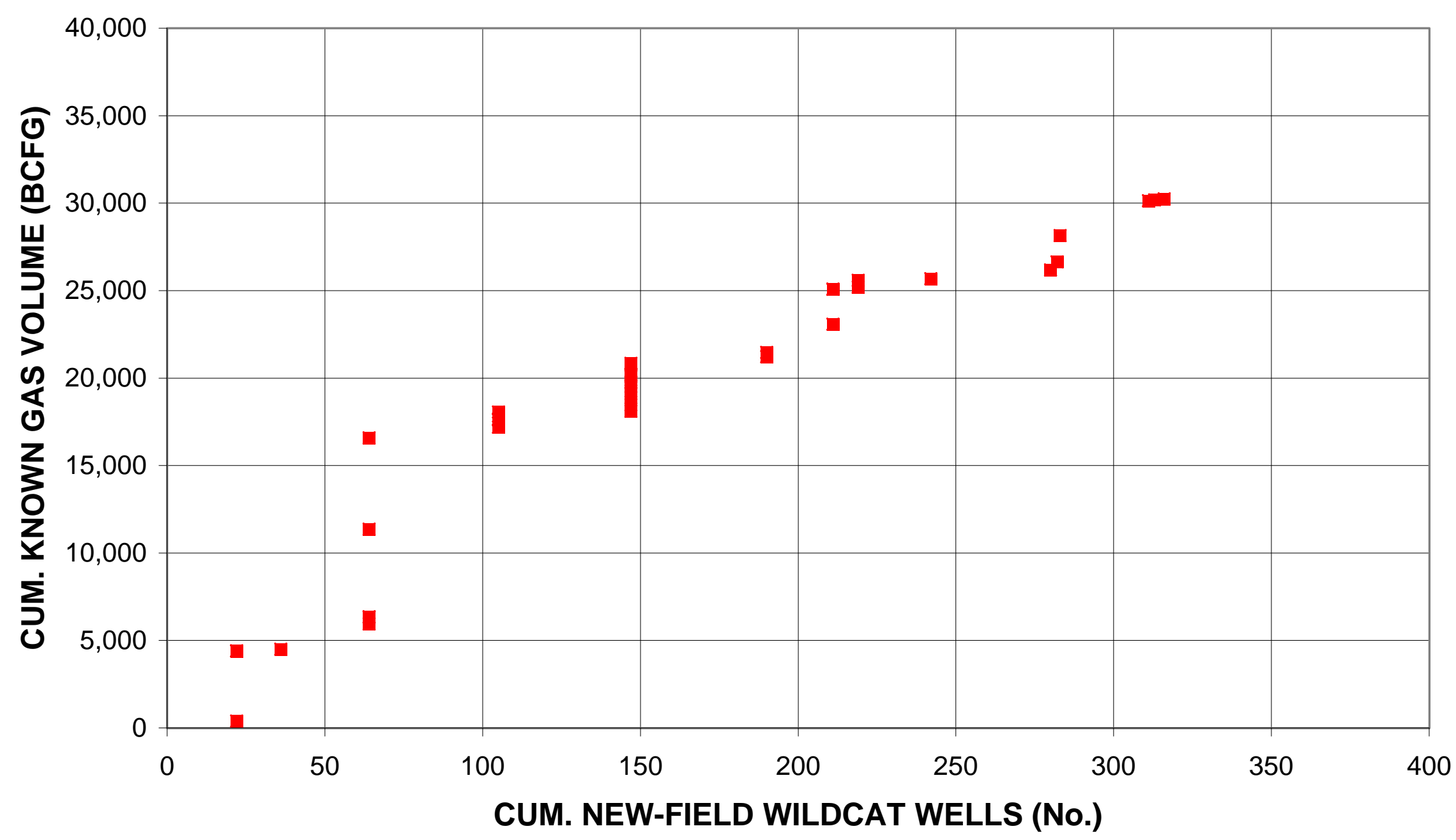


Tanezzuft-IIlizi Structural/Stratigraphic, Assessment Unit 20560101

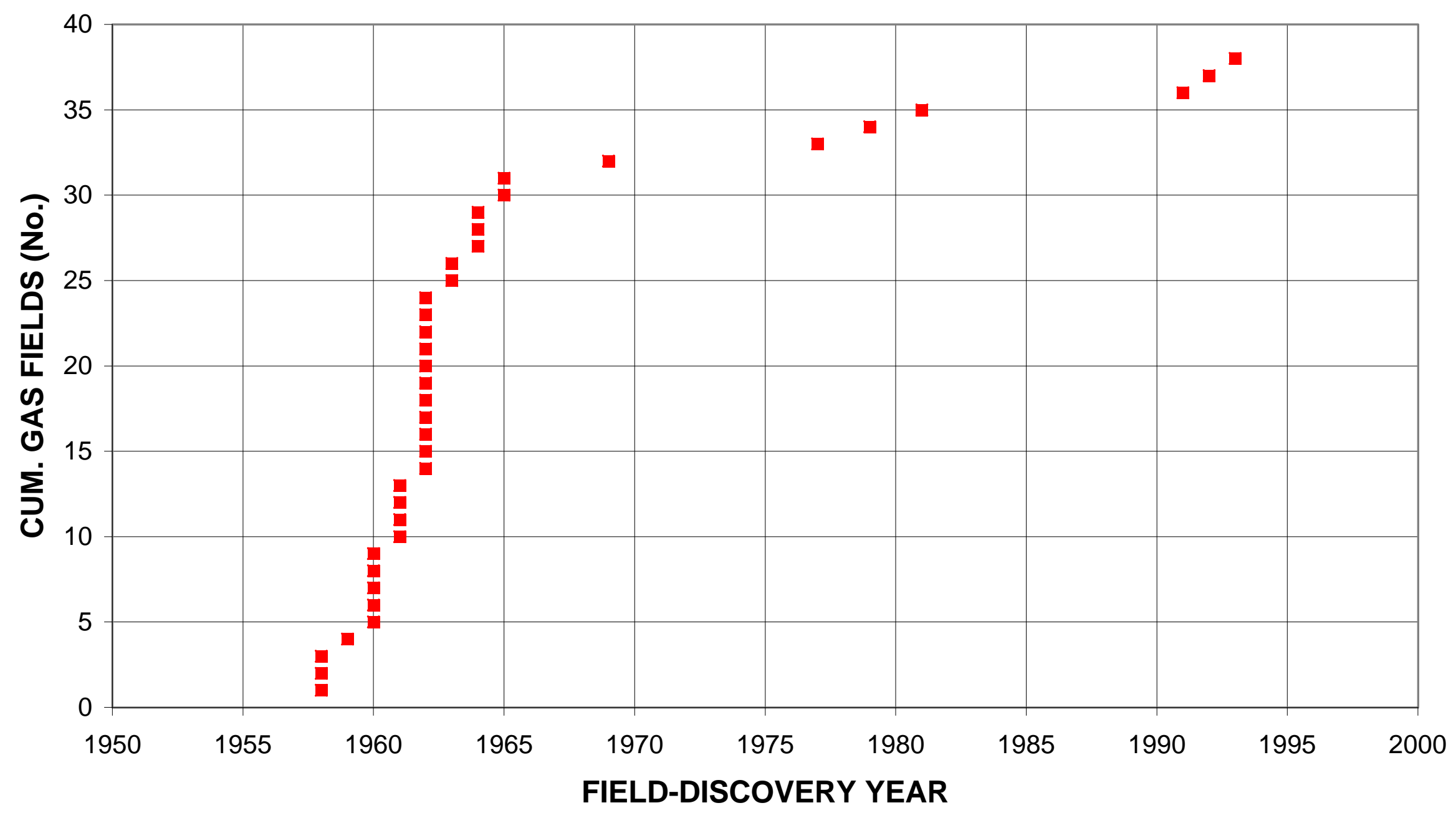


Tanezzuft-IIlizi Structural/Stratigraphic, Assessment Unit 20560101

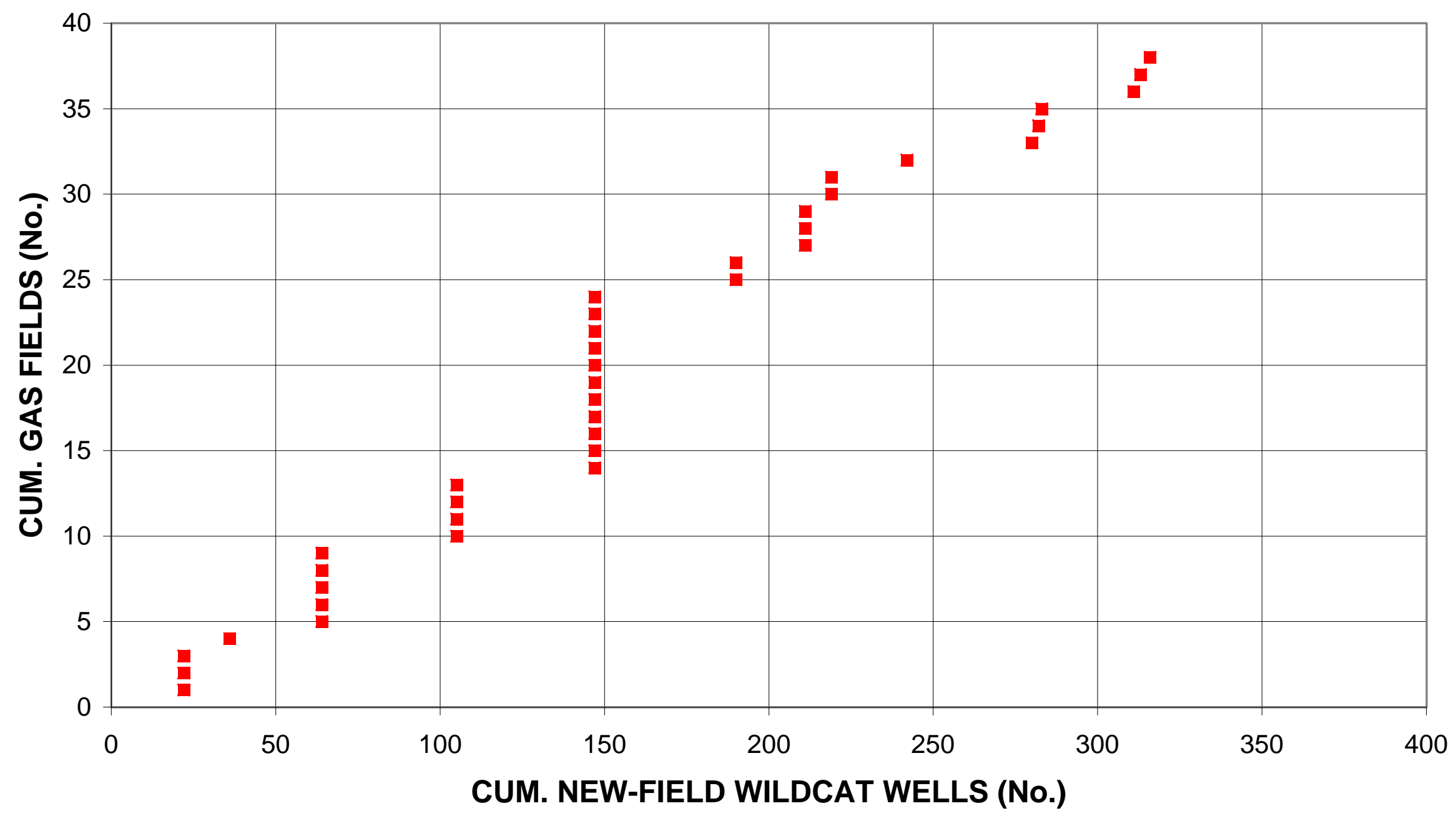


Tanezzuft-Illizi Structural/Stratigraphic, Assessment Unit 20560101

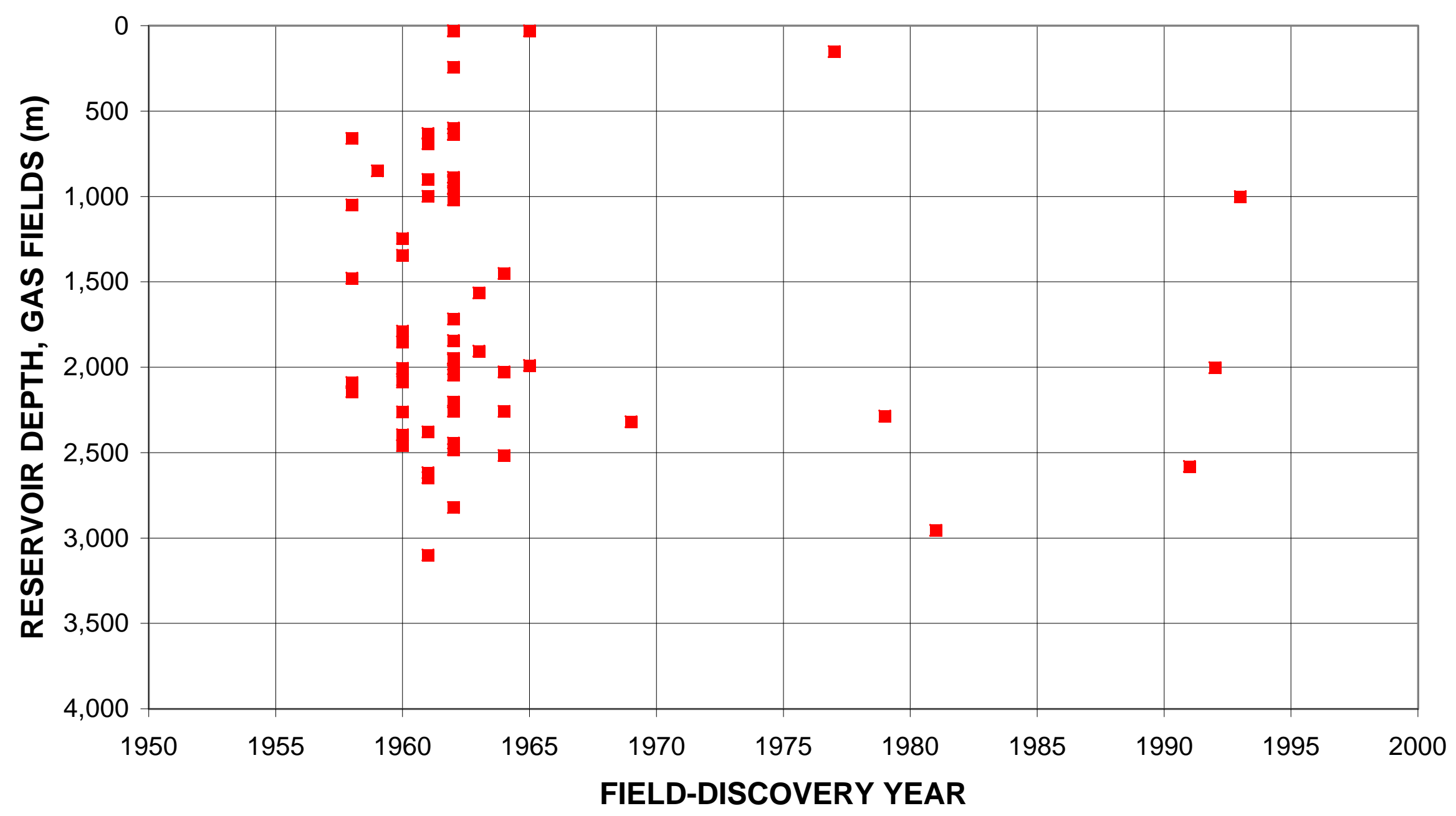


Tanezzuft-IIlizi Structural/Stratigraphic, Assessment Unit 20560101

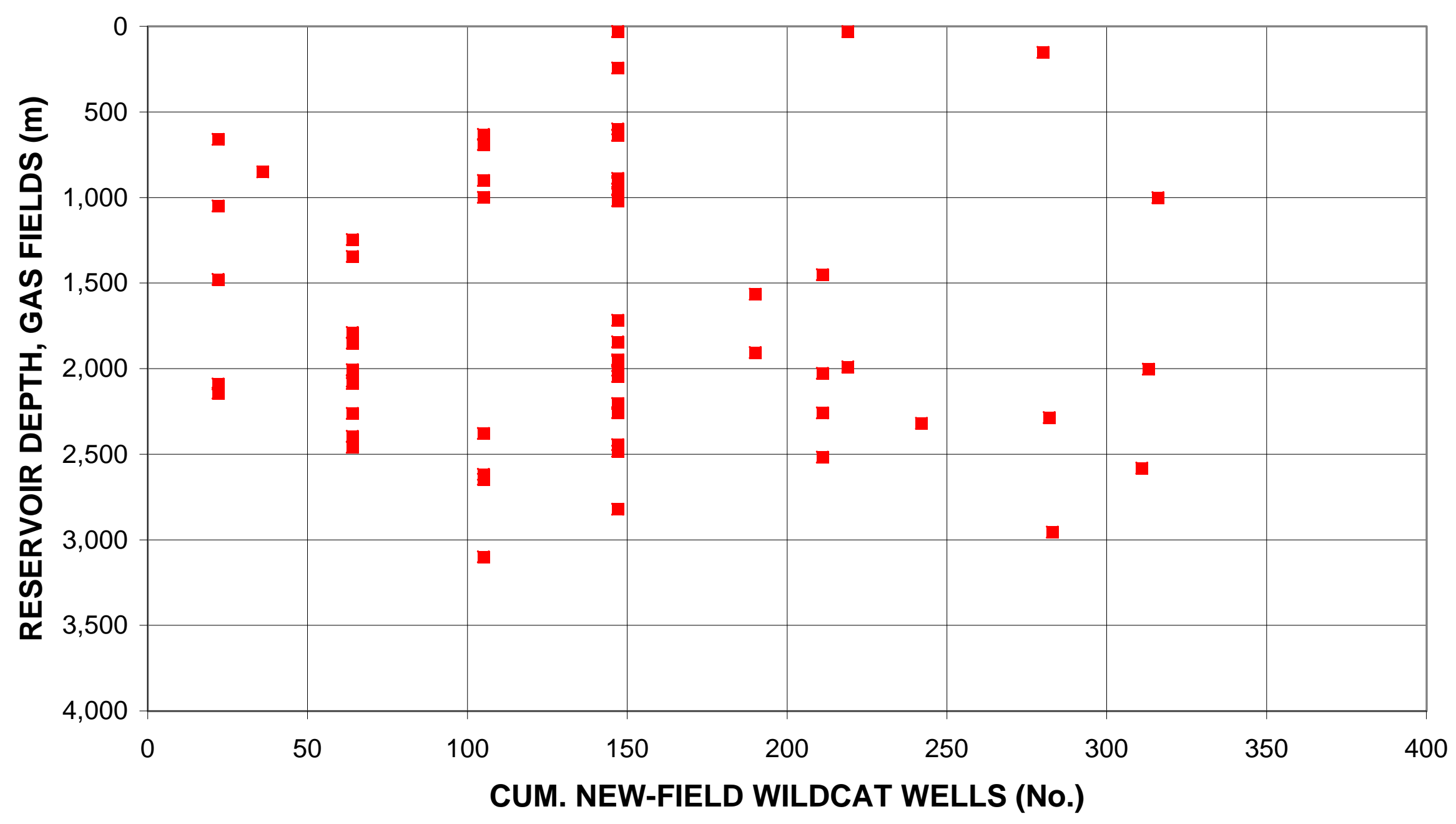


Tanezzuft-IIlizi Structural/Stratigraphic, Assessment Unit 20560101

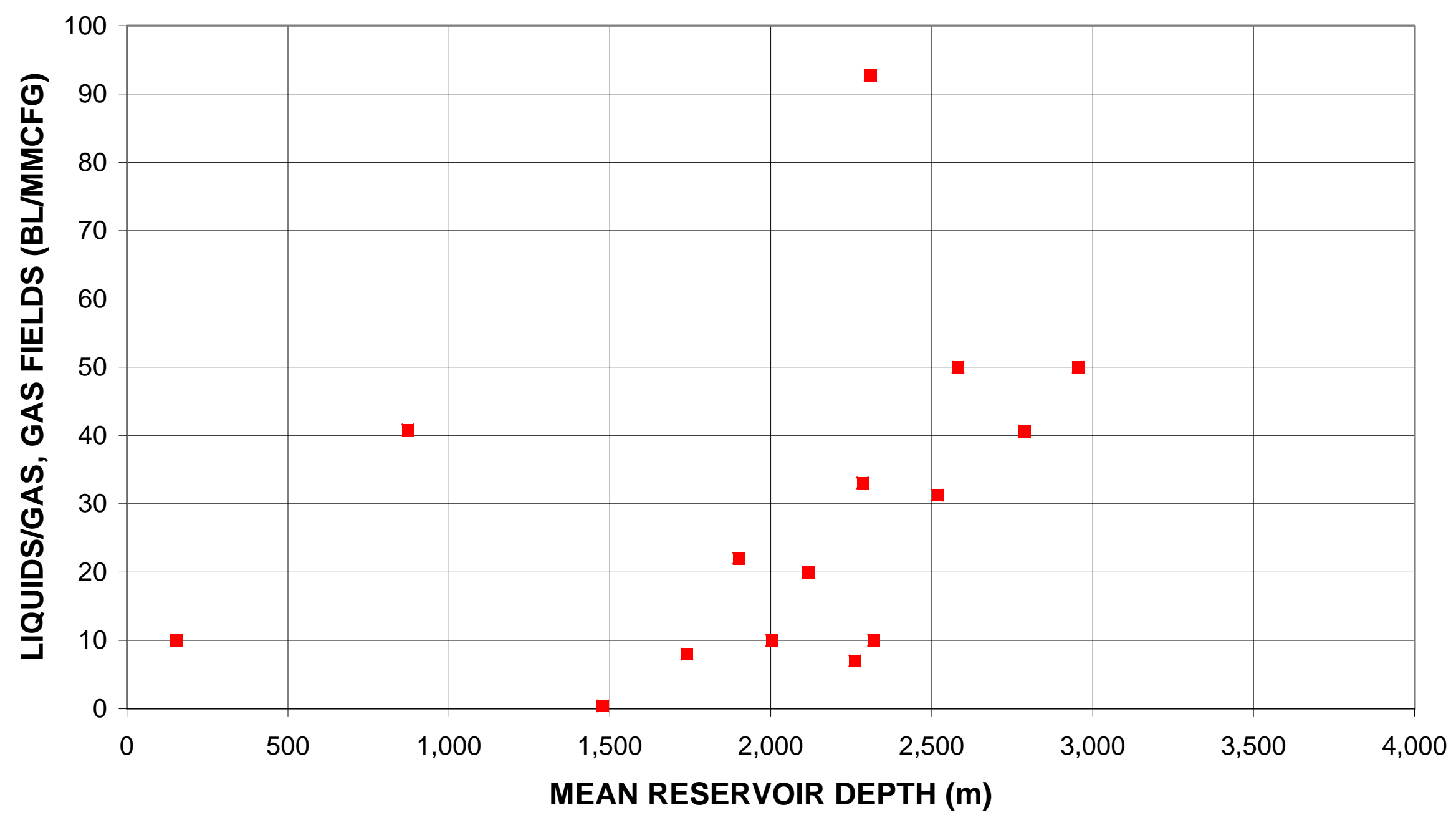




\section{Tanezzuft-Illizi Structural/Stratigraphic, Assessment Unit}

20560101

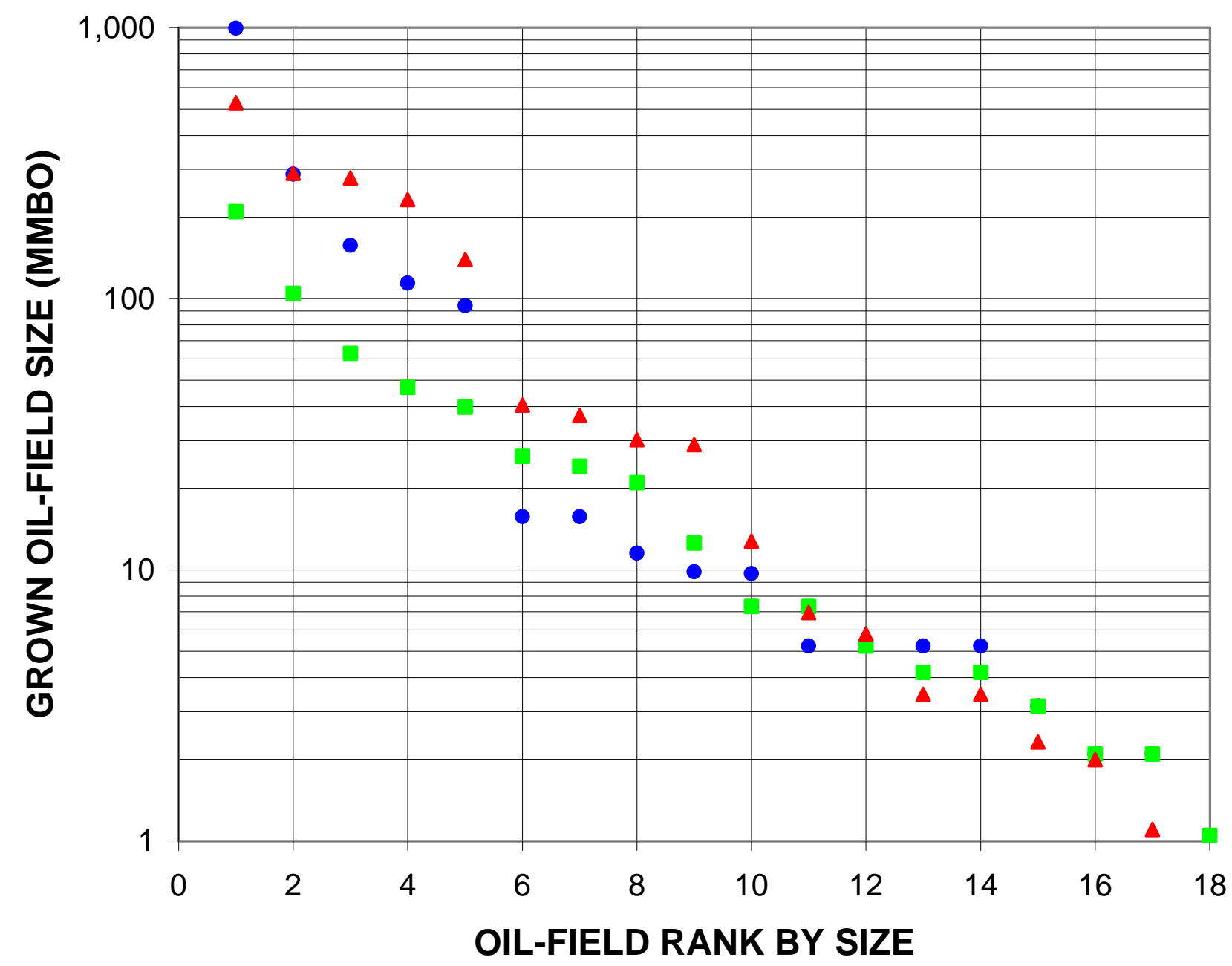

- First third of fields discovered

- Second third of fields discovered

$\Delta$ Third third of fields discovered 


\section{Tanezzuft-IIlizi Structural/Stratigraphic, Assessment Unit}

20560101
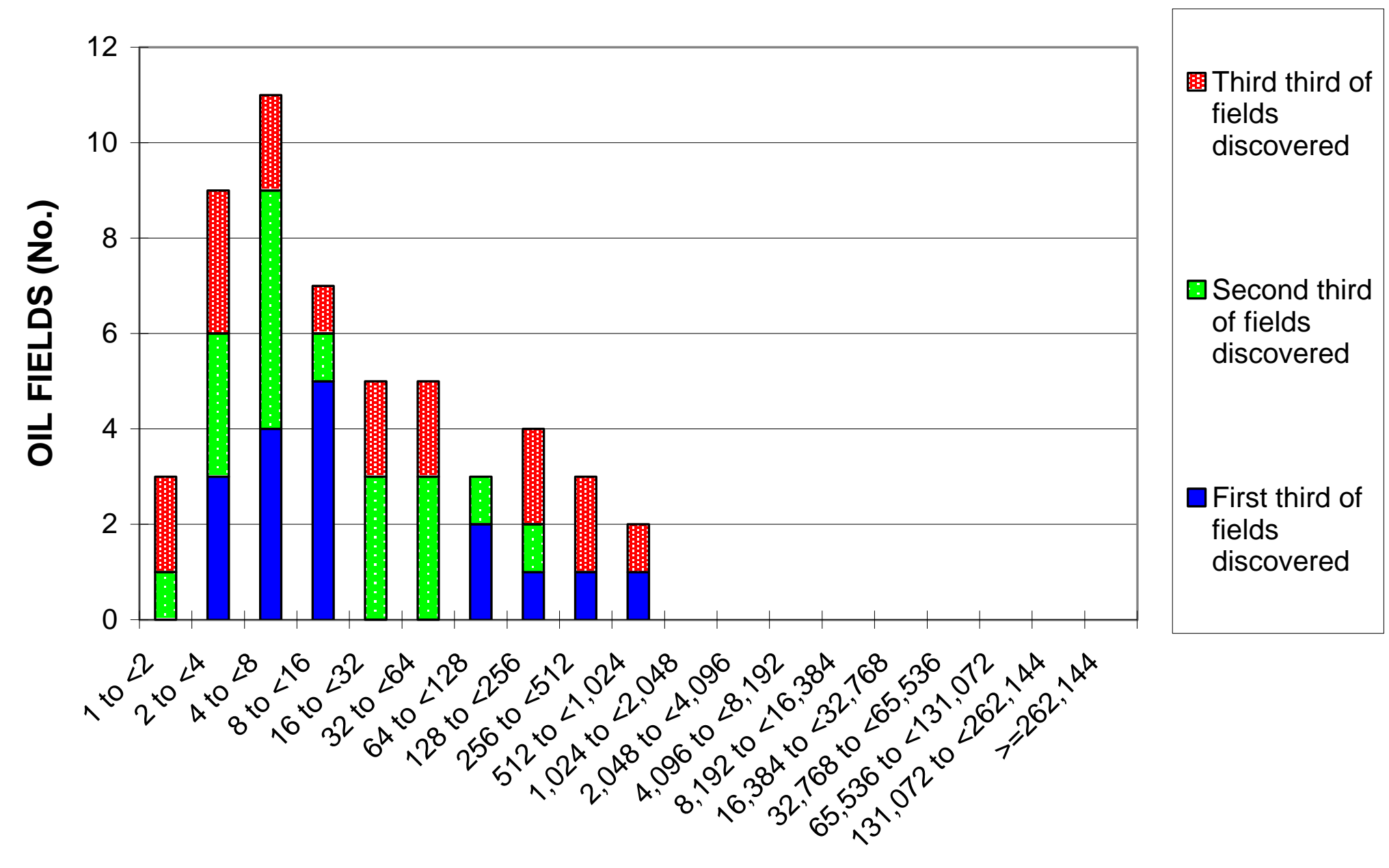

GROWN OIL-FIELD SIZE (MMBO) 
Tanezzuft-Illizi Structural/Stratigraphic, Assessment Unit 20560101

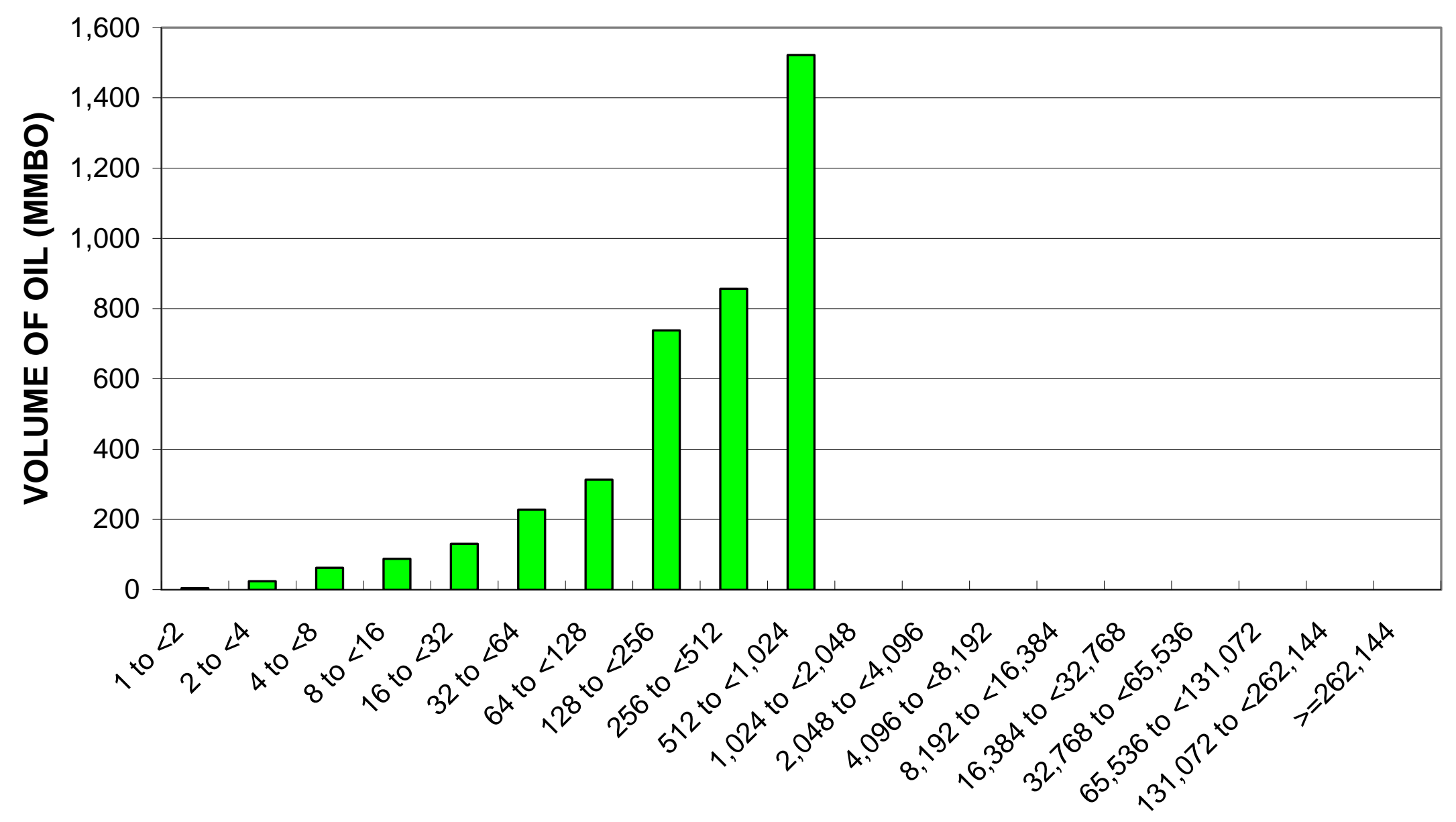

GROWN OIL-FIELD SIZE (MMBO) 
Tanezzuft-Illizi Structural/Stratigraphic, Assessment Unit 20560101

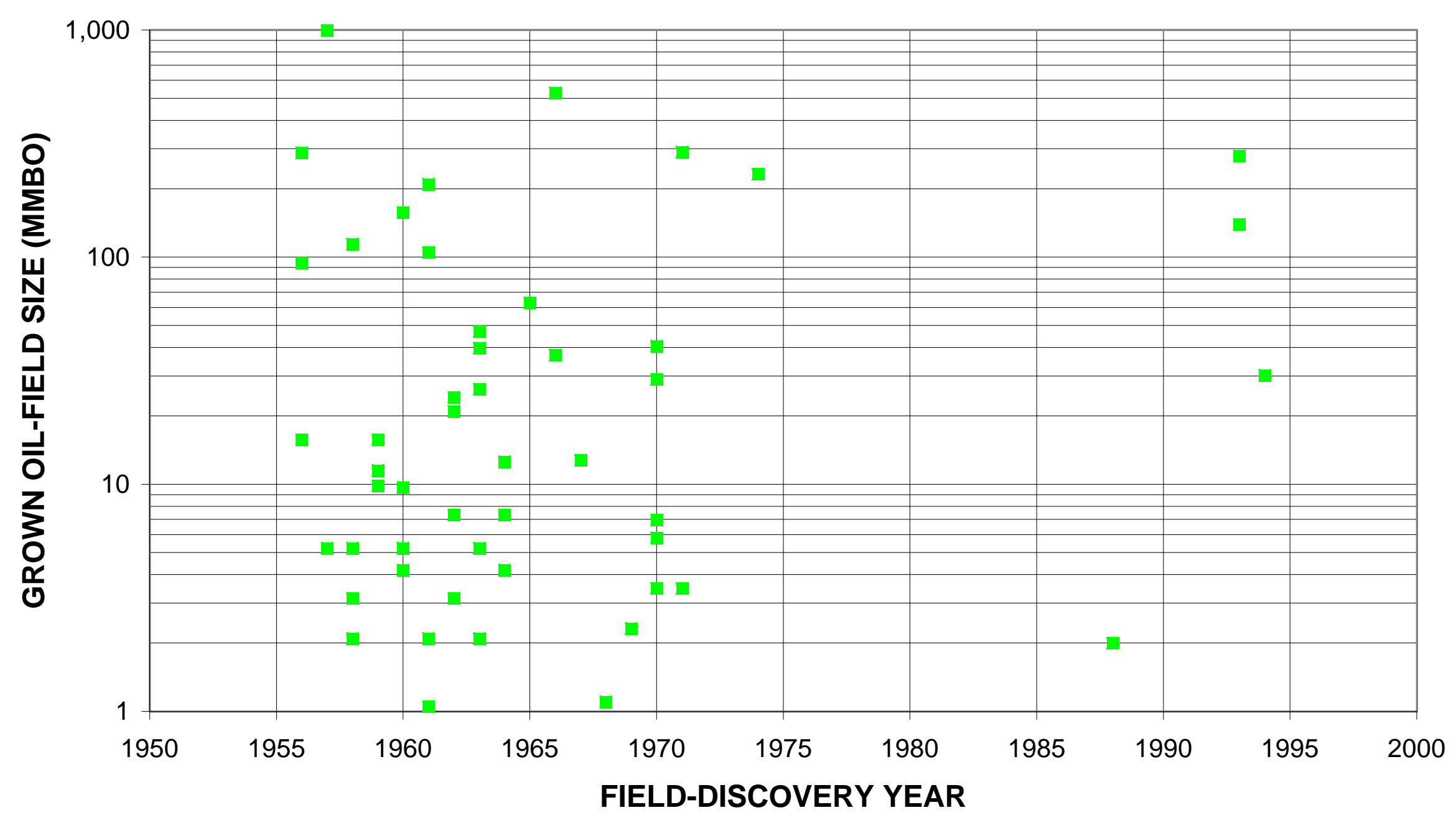


Tanezzuft-Illizi Structural/Stratigraphic, Assessment Unit 20560101

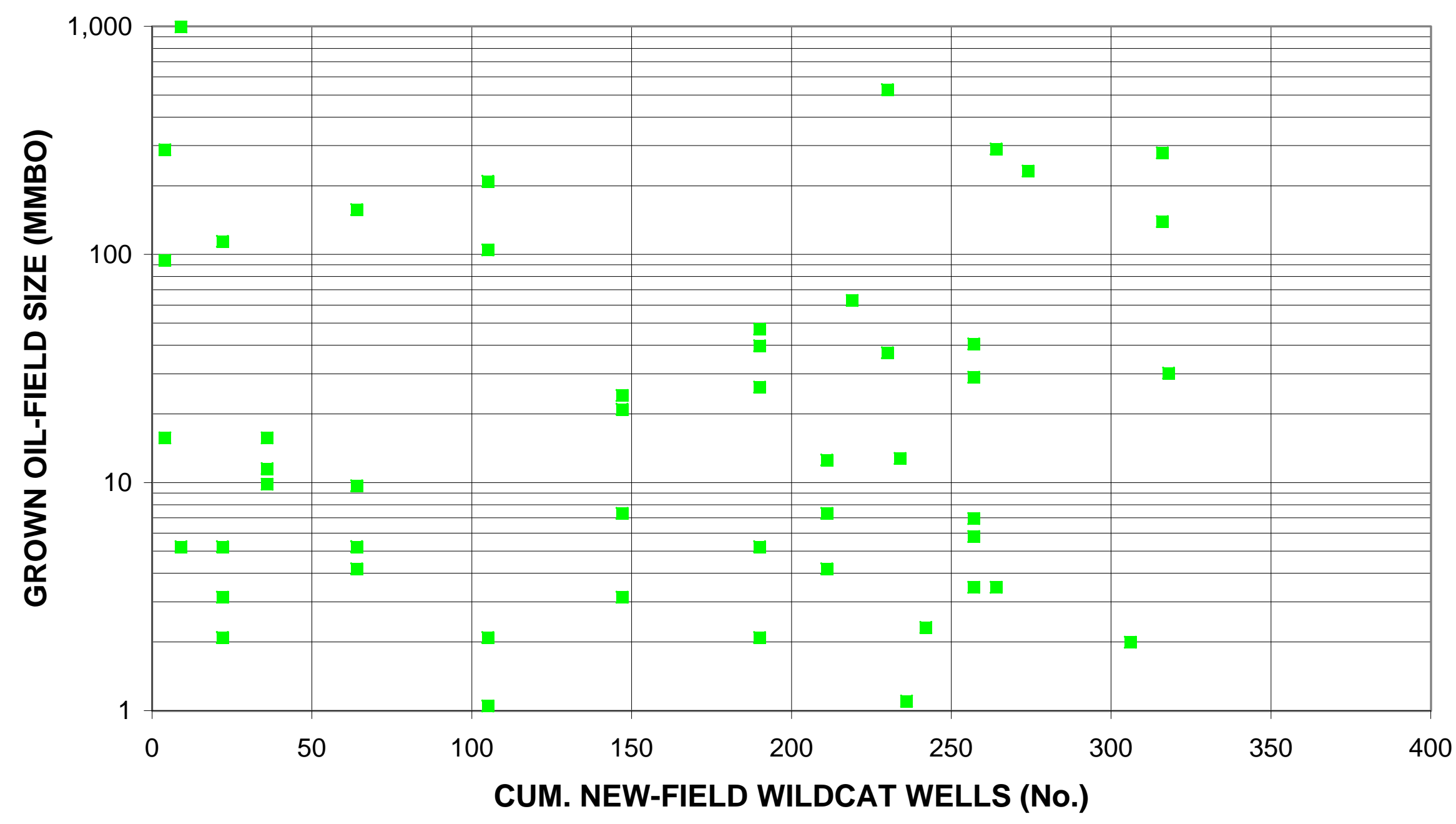


Tanezzuft-IIlizi Structural/Stratigraphic, Assessment Unit 20560101

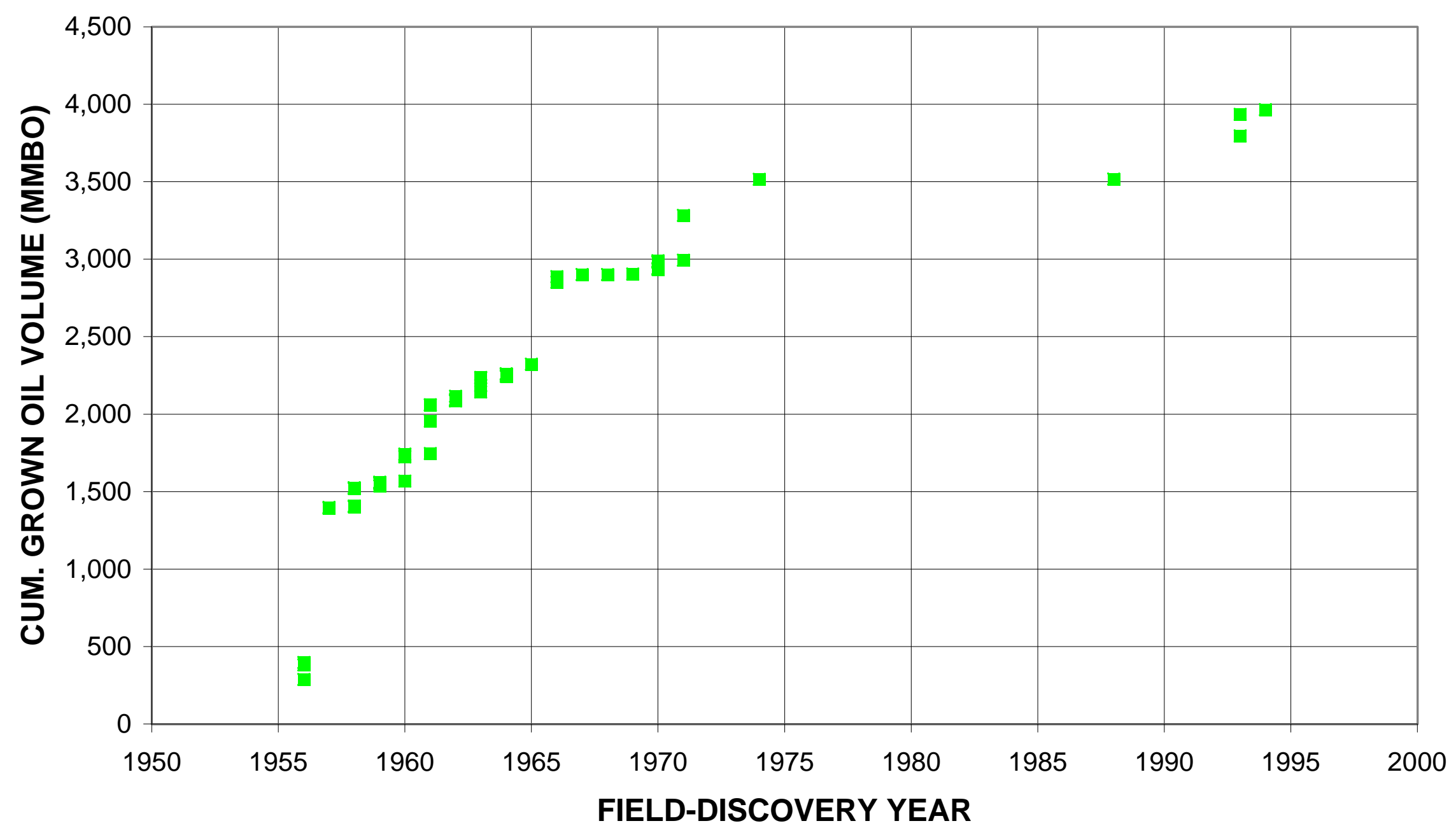


Tanezzuft-IIlizi Structural/Stratigraphic, Assessment Unit 20560101

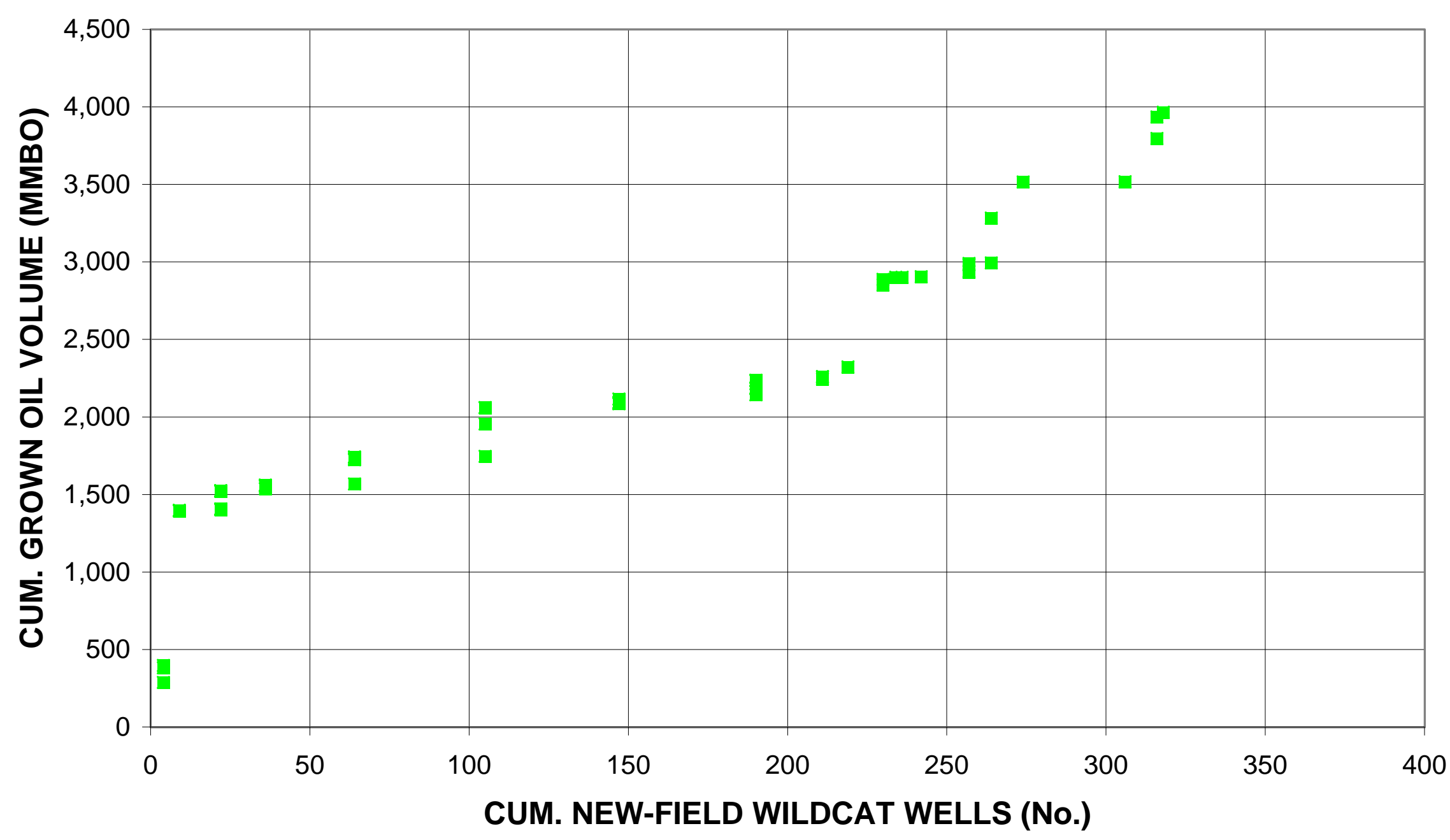


Tanezzuft-IIlizi Structural/Stratigraphic, Assessment Unit 20560101

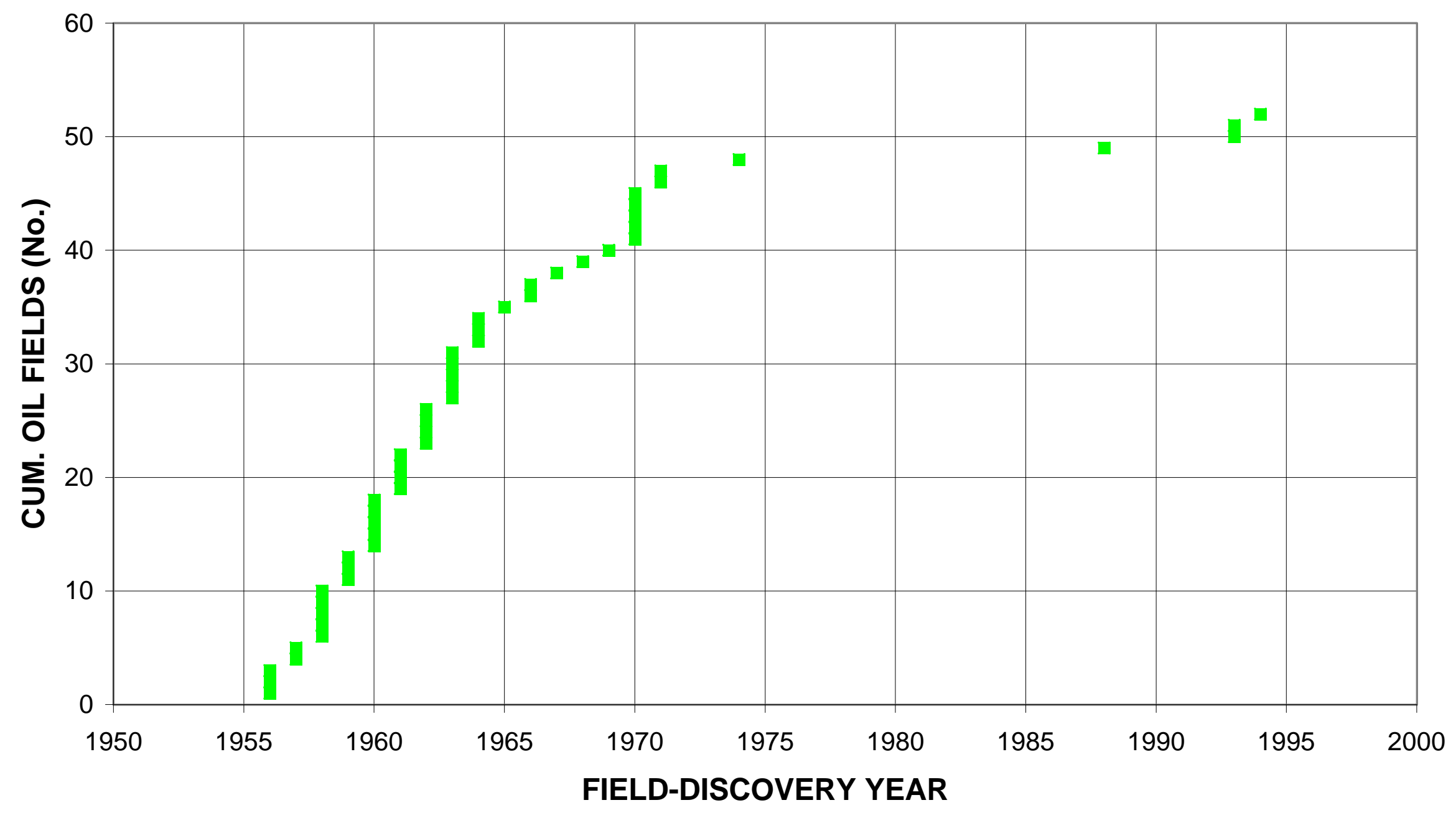


Tanezzuft-IIlizi Structural/Stratigraphic, Assessment Unit 20560101

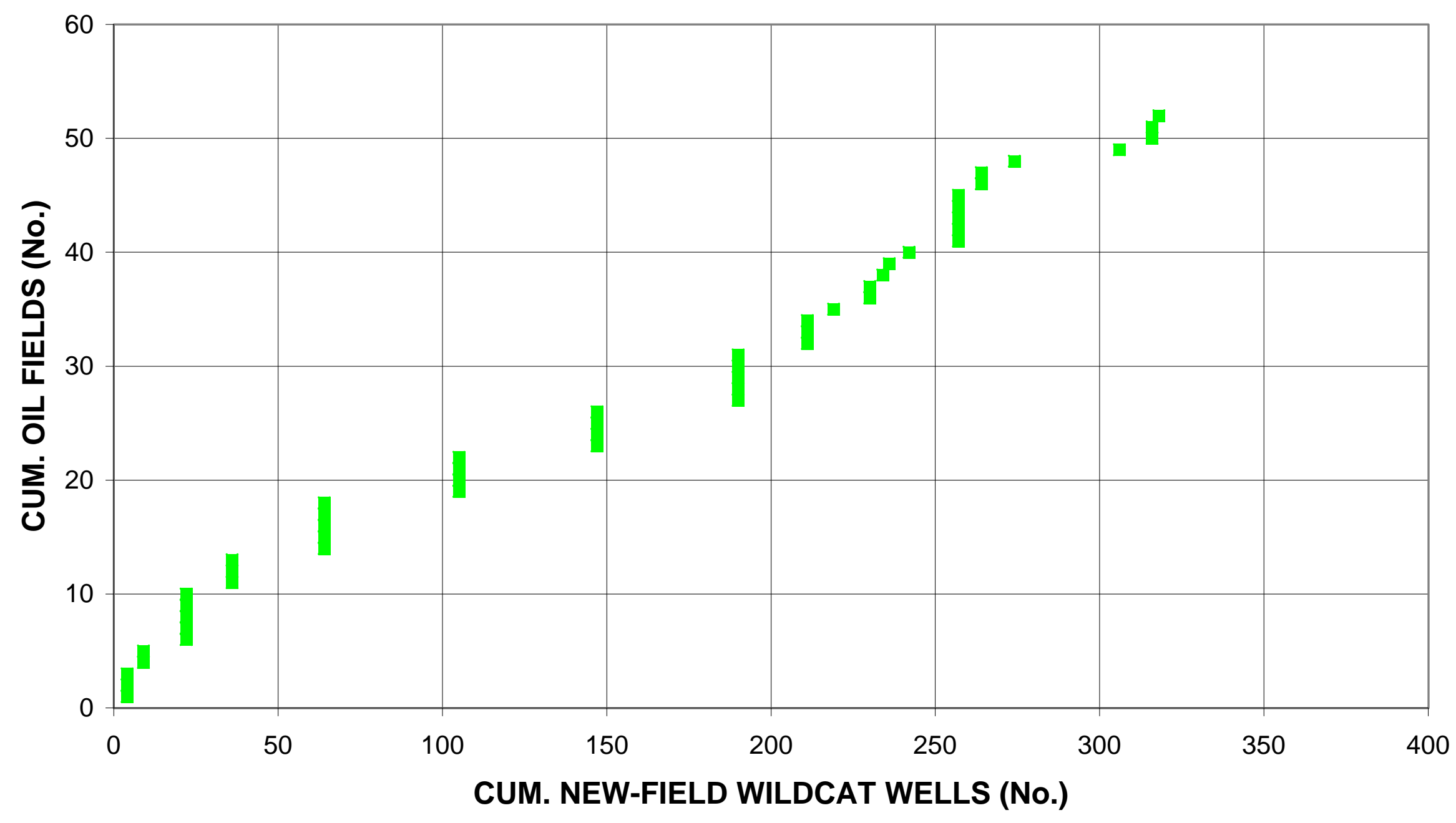


Tanezzuft-Illizi Structural/Stratigraphic, Assessment Unit 20560101

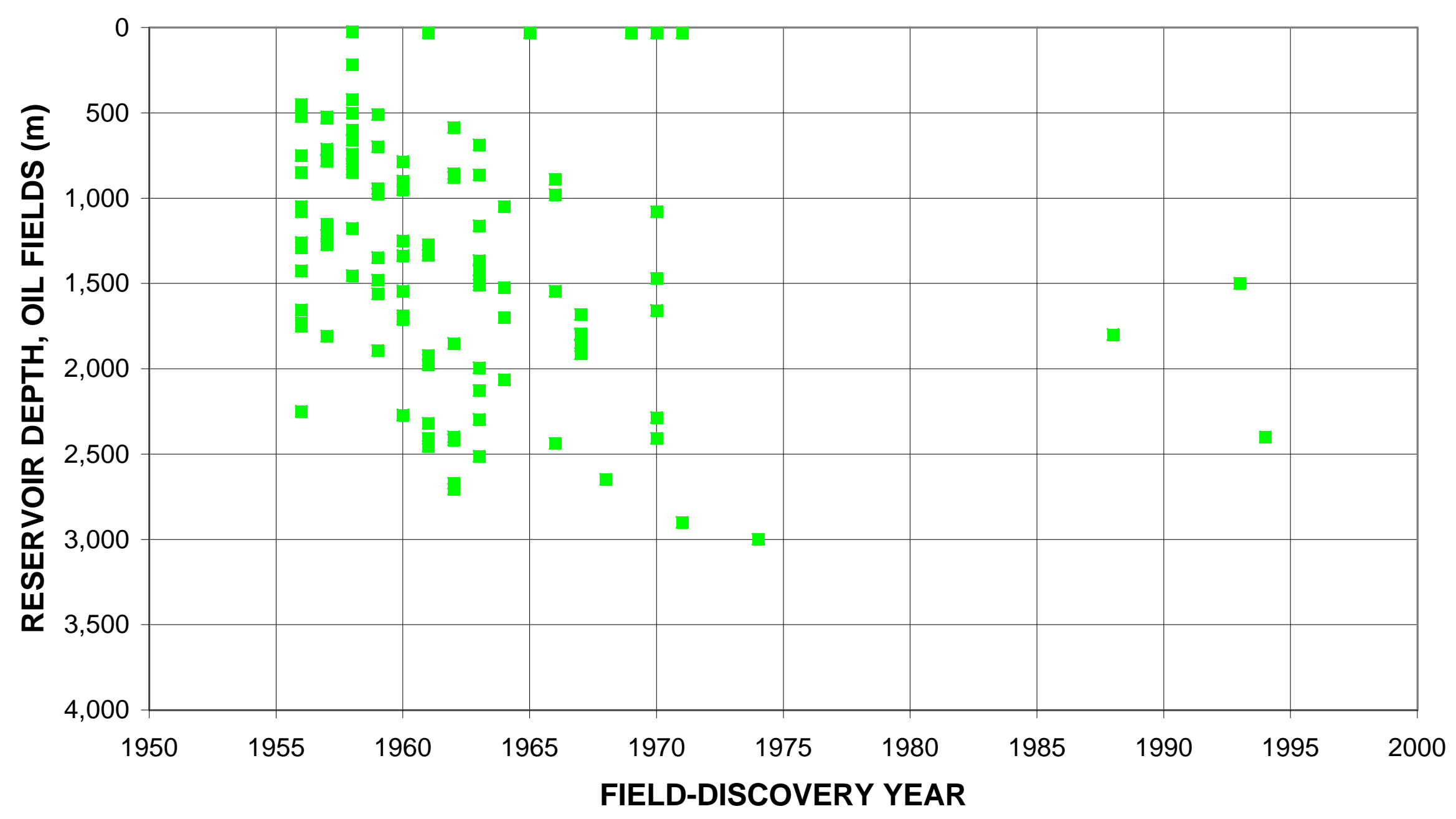


Tanezzuft-IIlizi Structural/Stratigraphic, Assessment Unit 20560101

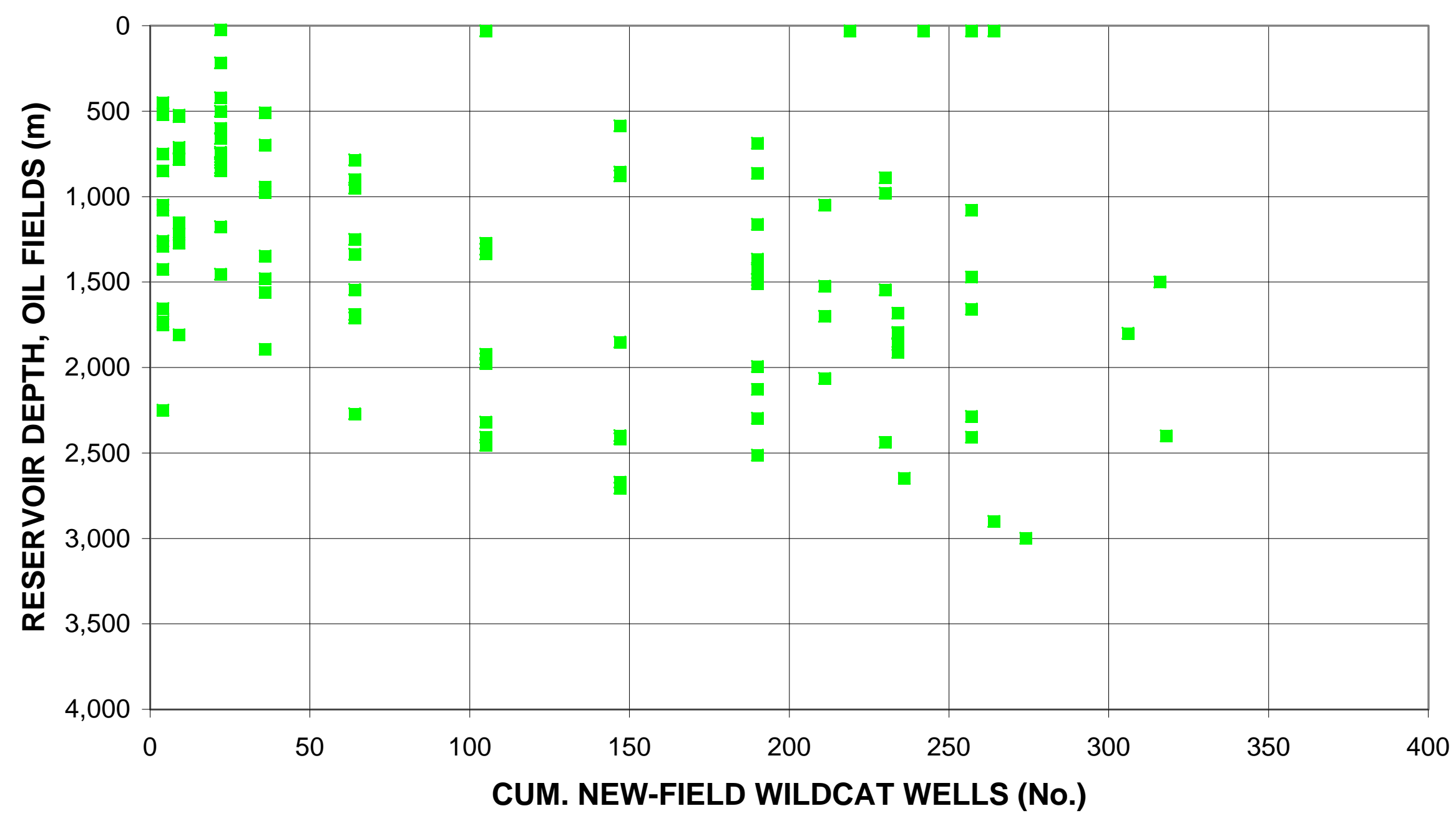


Tanezzuft-IIlizi Structural/Stratigraphic, Assessment Unit 20560101

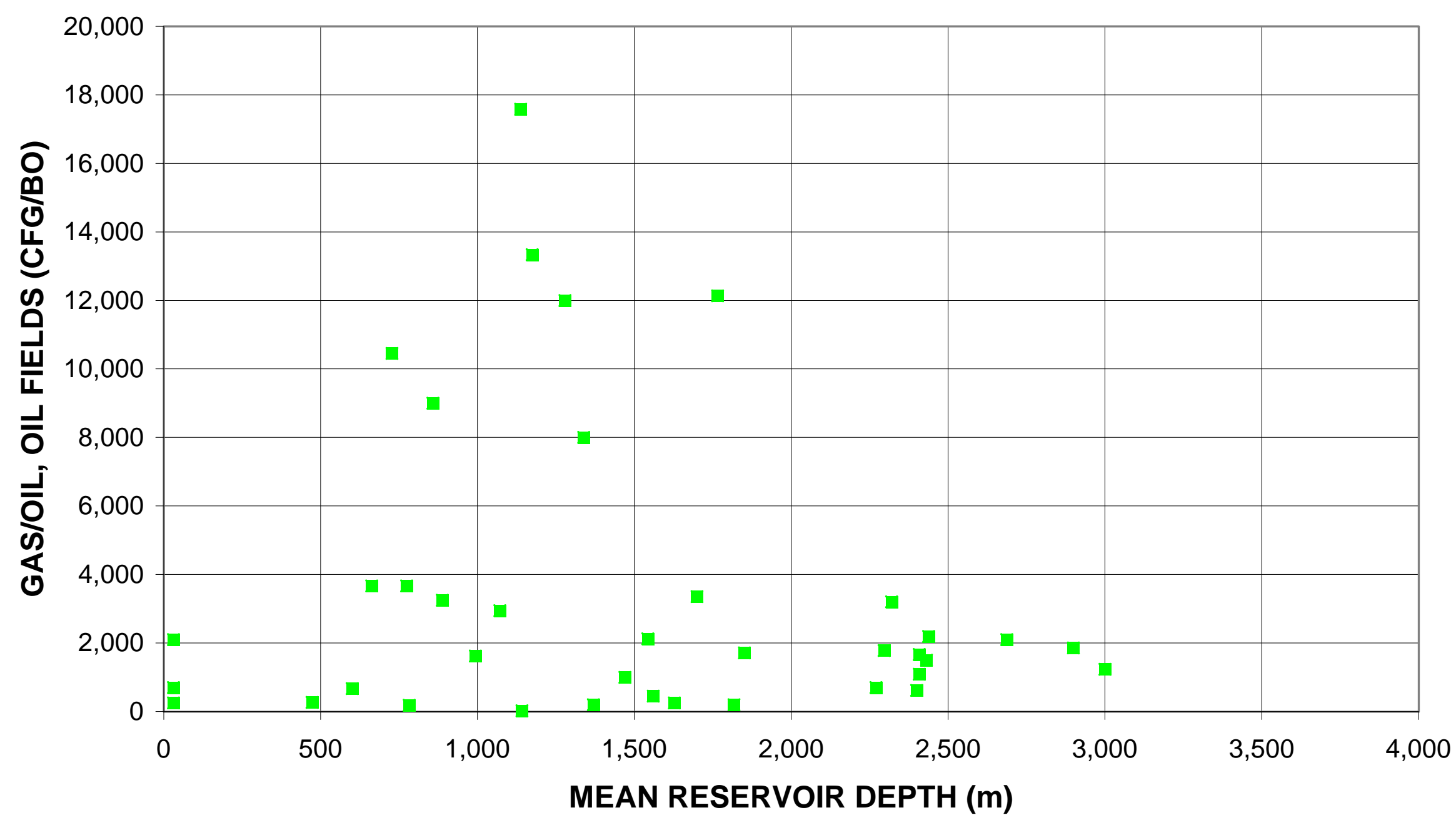


Tanezzuft-IIlizi Structural/Stratigraphic, Assessment Unit 20560101

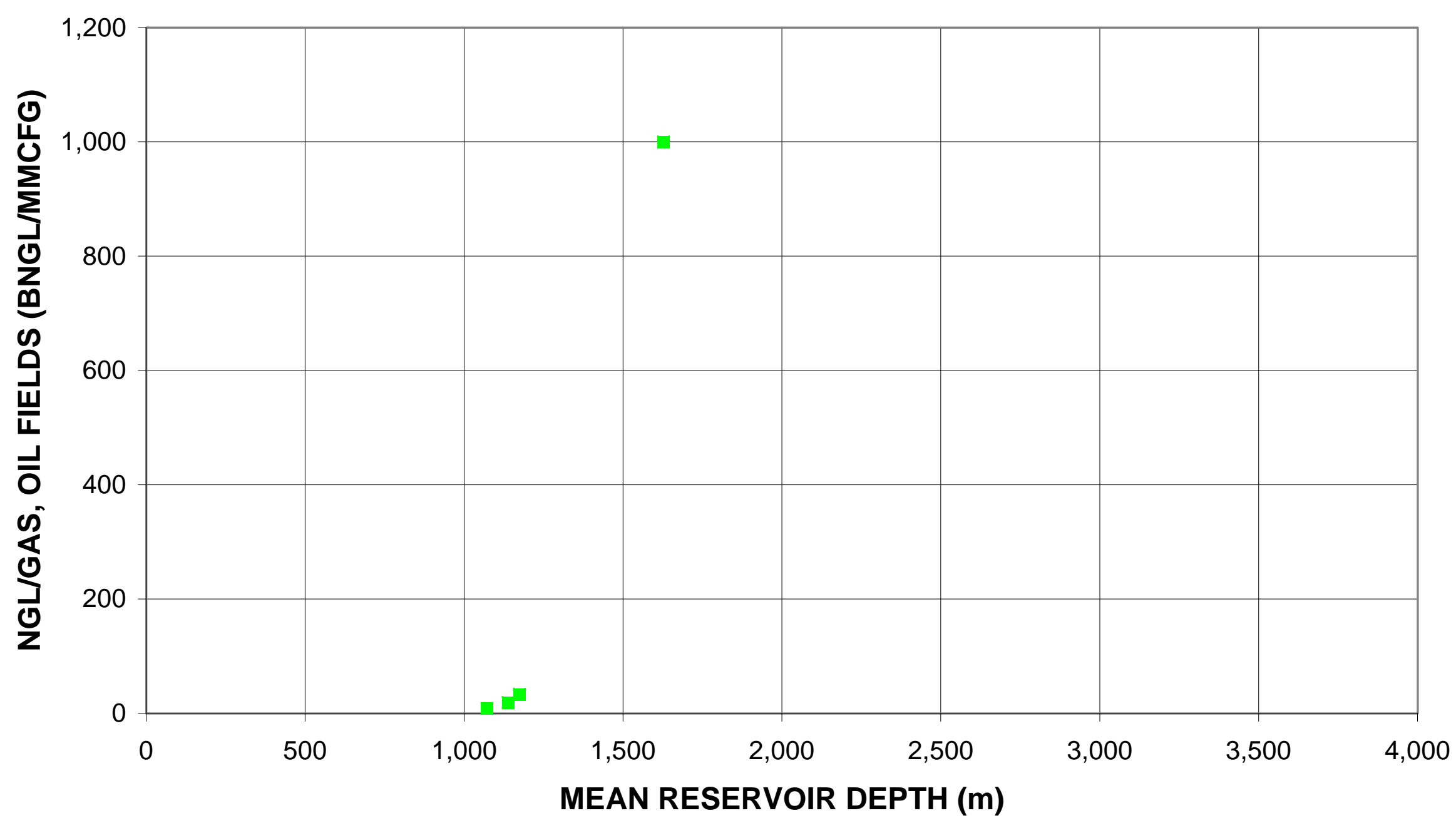


Tanezzuft-Illizi Structural/Stratigraphic, Assessment Unit 20560101

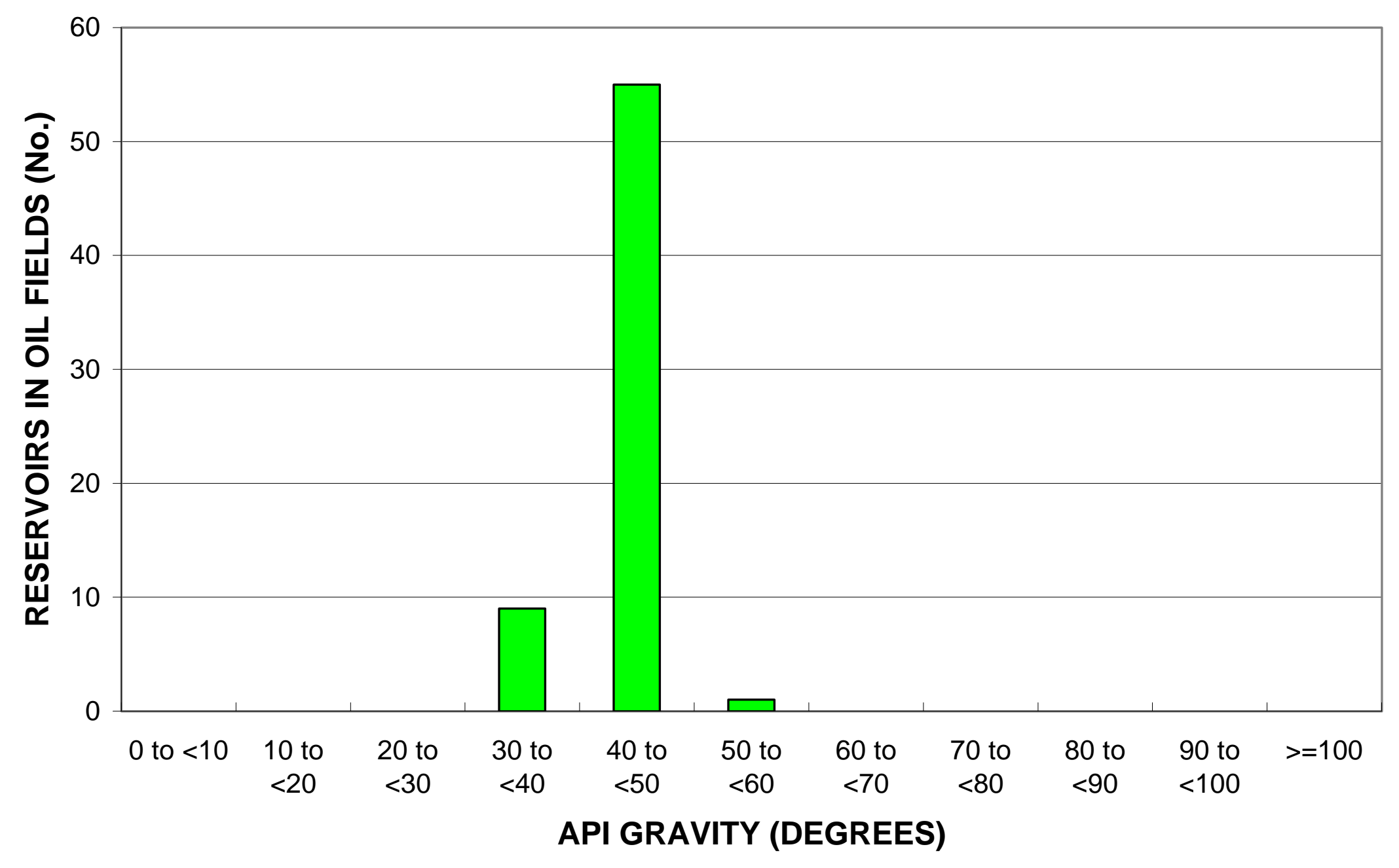




\section{Tanezzuft-Illizi Structural/Stratigraphic, Assessment Unit 20560101}

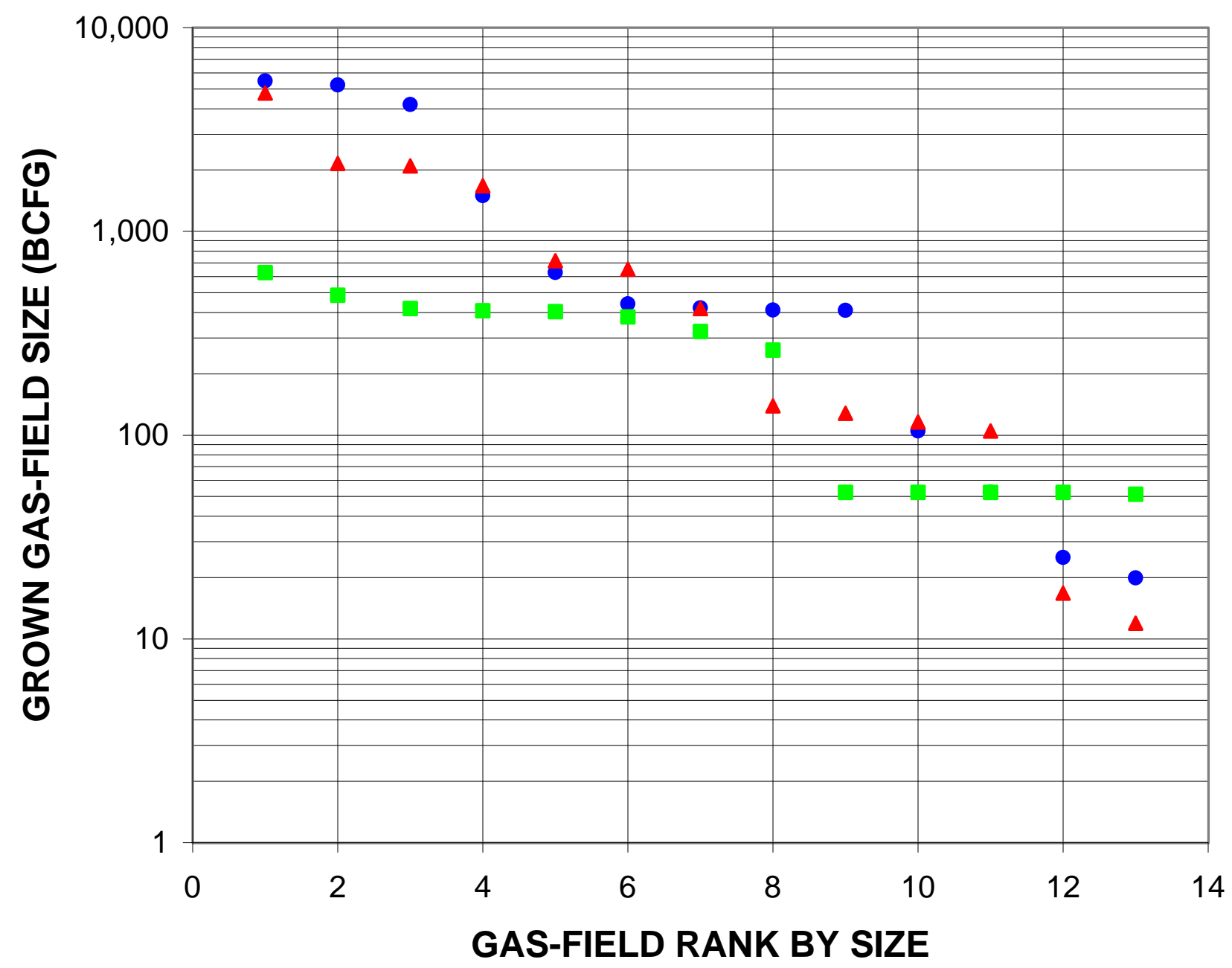

- First third of fields discovered

- Second third of fields discovered

$\Delta$ Third third of fields discovered 
Tanezzuft-Illizi Structural/Stratigraphic, Assessment Unit 20560101

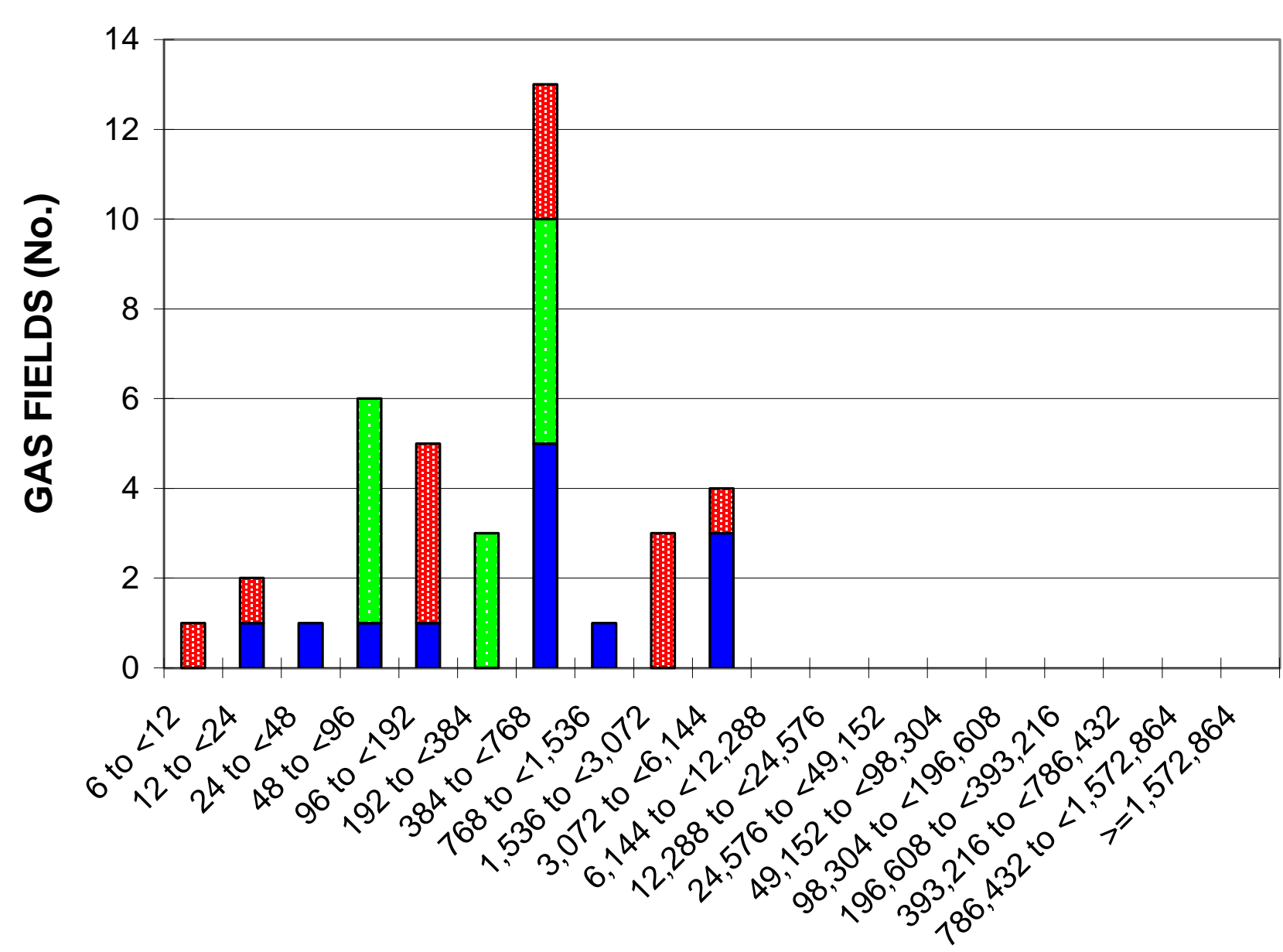

国 Third third of

fields

discovered

$\square$ Second third of fields

discovered

First third of

fields

discovered

GROWN GAS-FIELD SIZE (BCFG) 
Tanezzuft-Illizi Structural/Stratigraphic, Assessment Unit 20560101

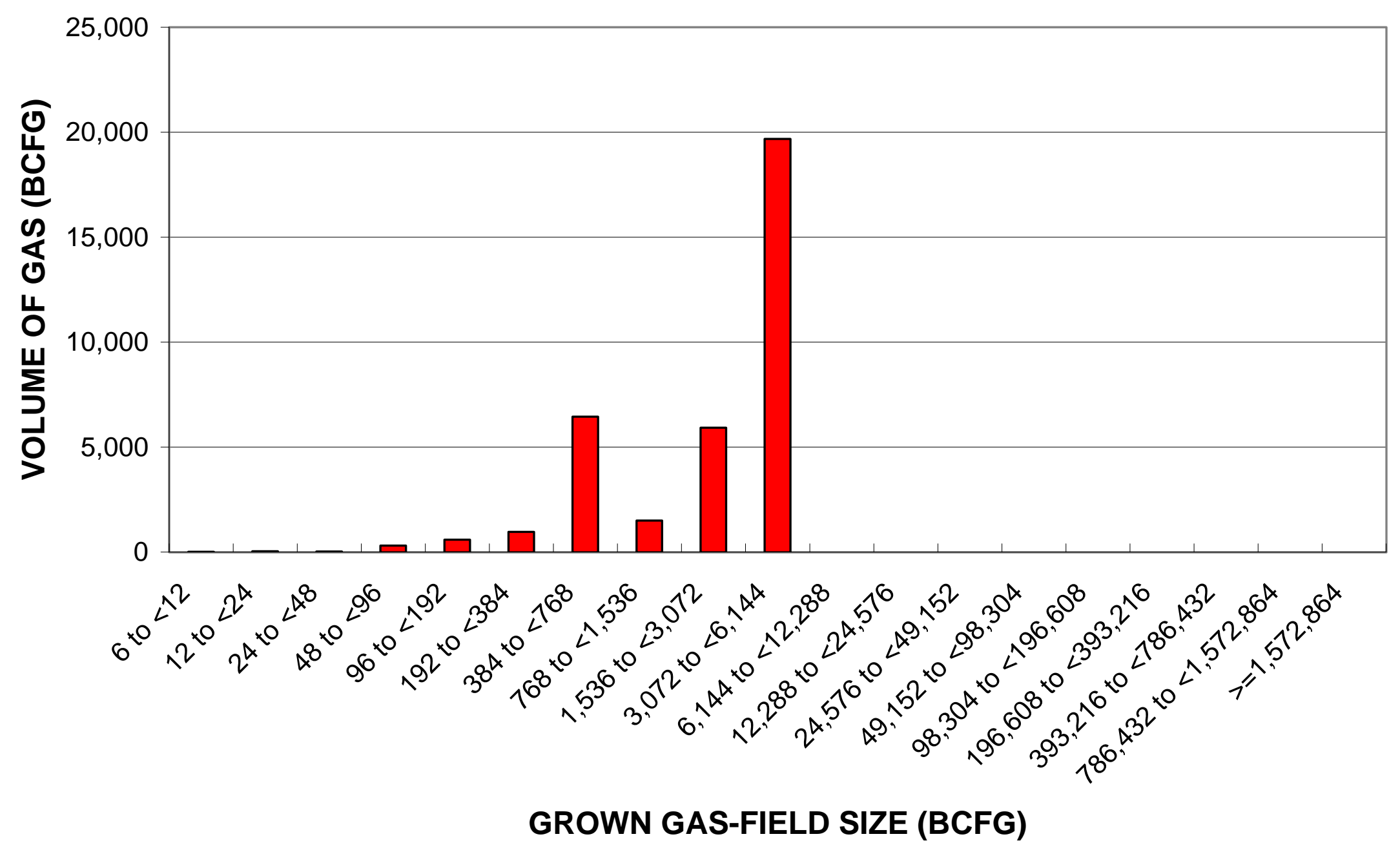


Tanezzuft-Illizi Structural/Stratigraphic, Assessment Unit 20560101

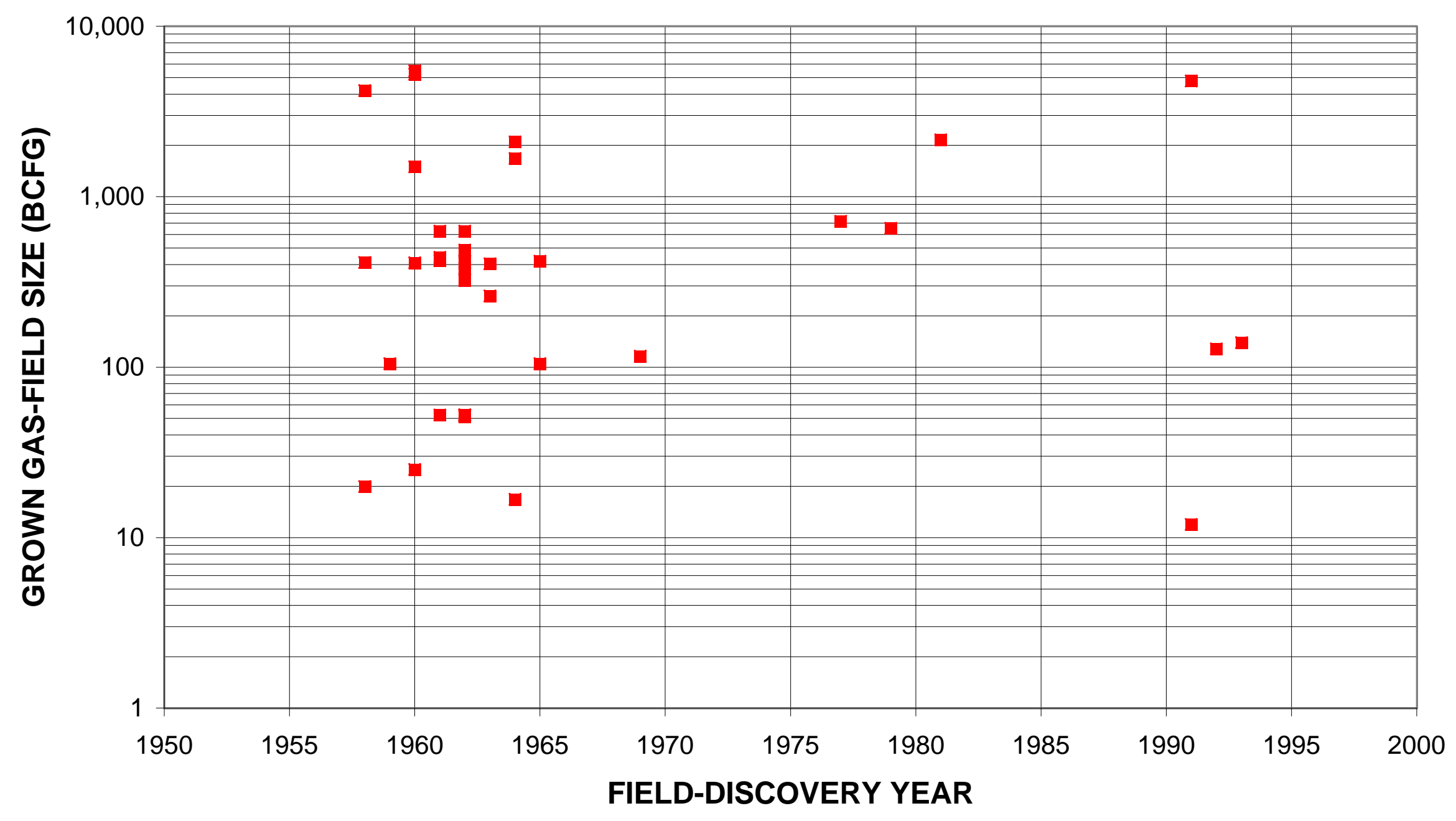


Tanezzuft-IIlizi Structural/Stratigraphic, Assessment Unit 20560101

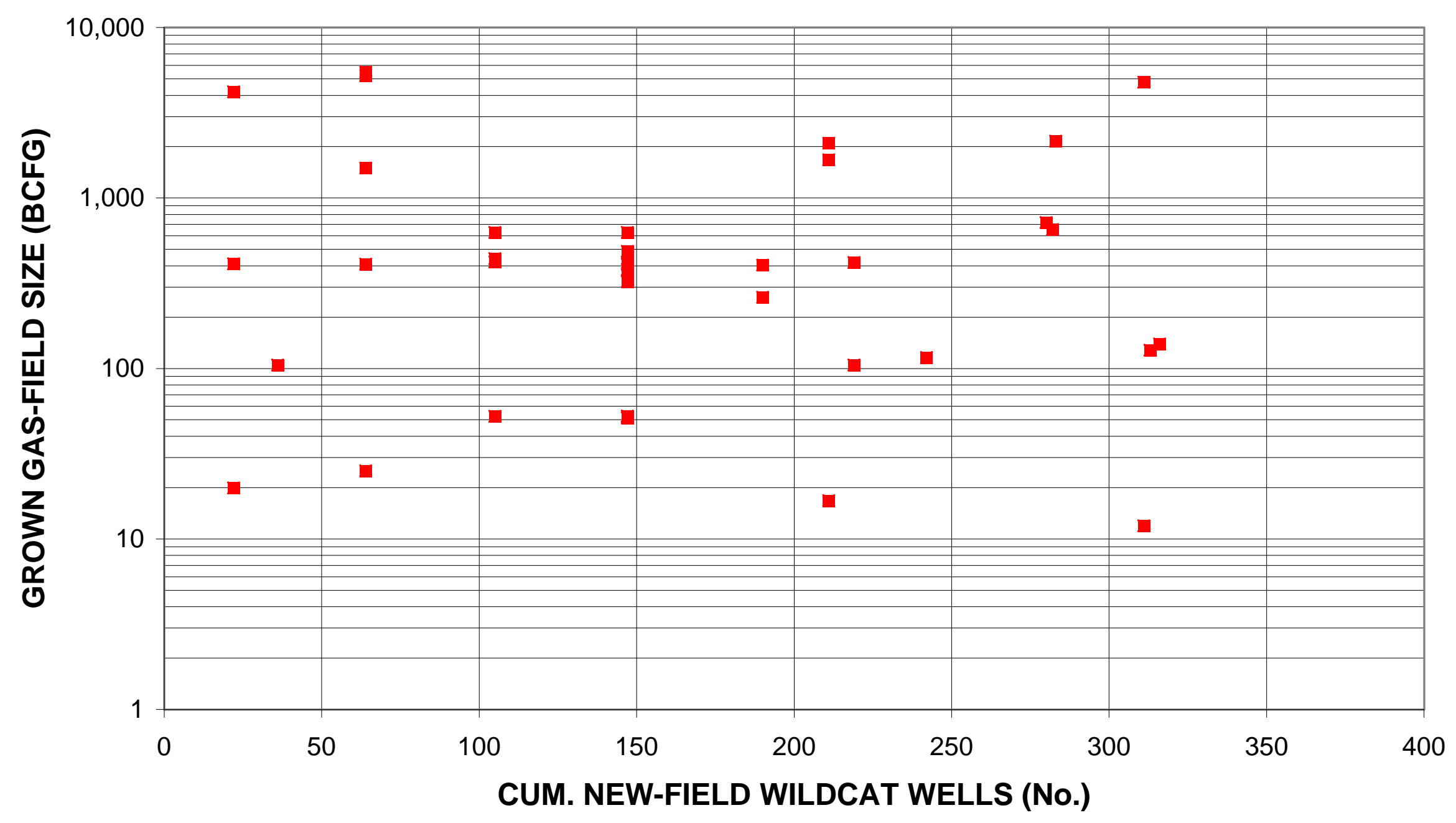


Tanezzuft-IIlizi Structural/Stratigraphic, Assessment Unit 20560101

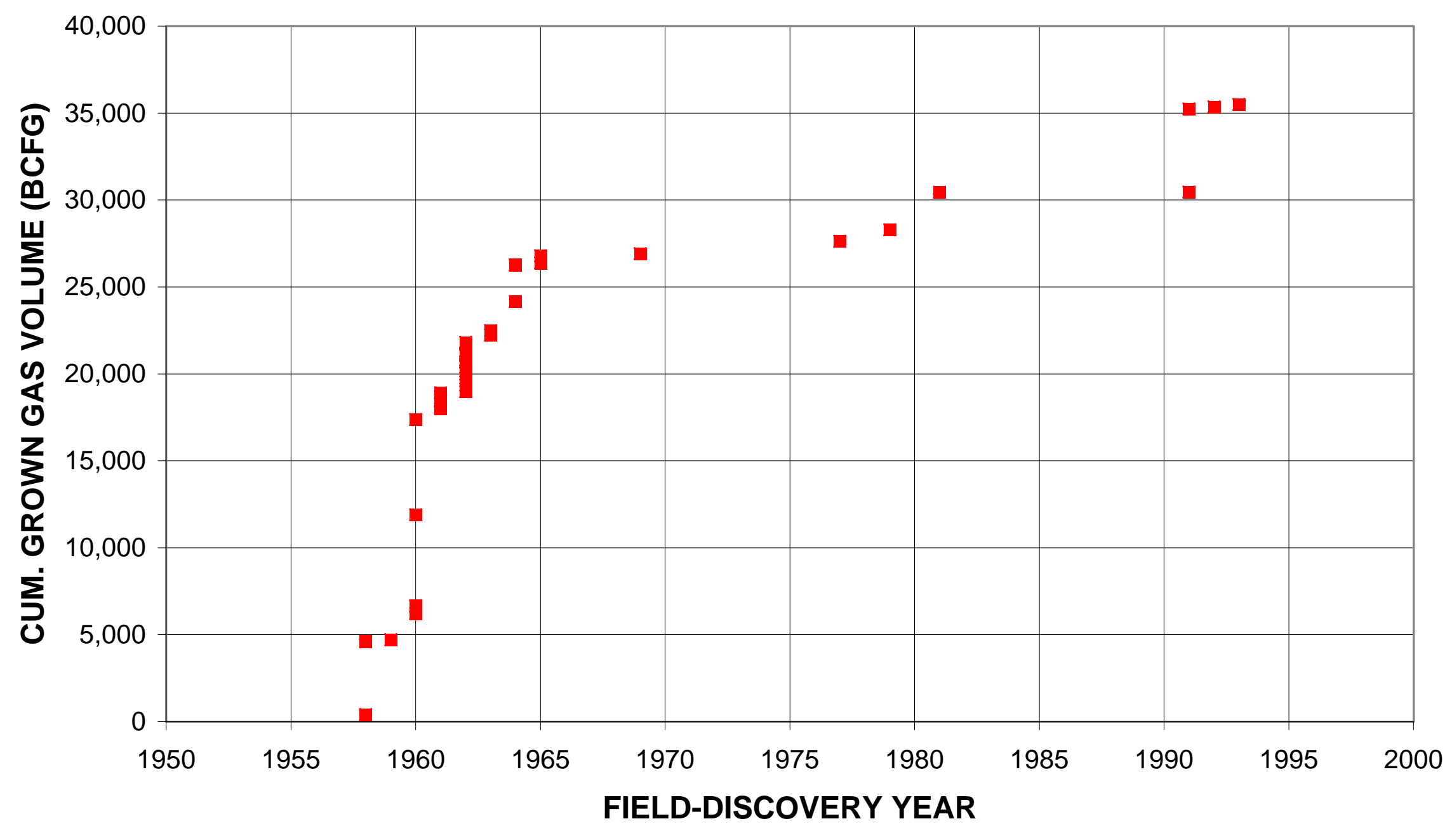


Tanezzuft-IIlizi Structural/Stratigraphic, Assessment Unit 20560101

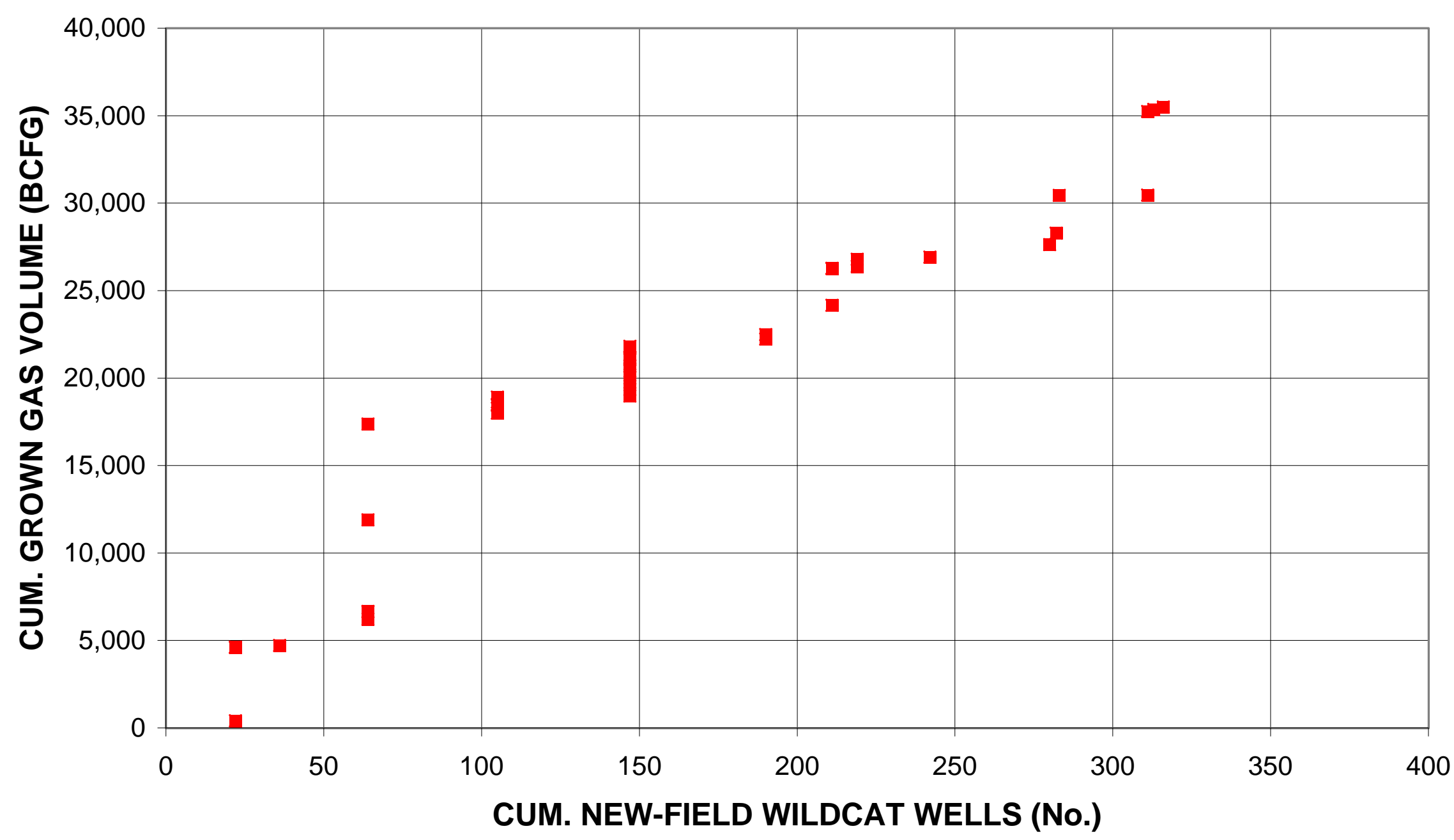


Tanezzuft-IIlizi Structural/Stratigraphic, Assessment Unit 20560101

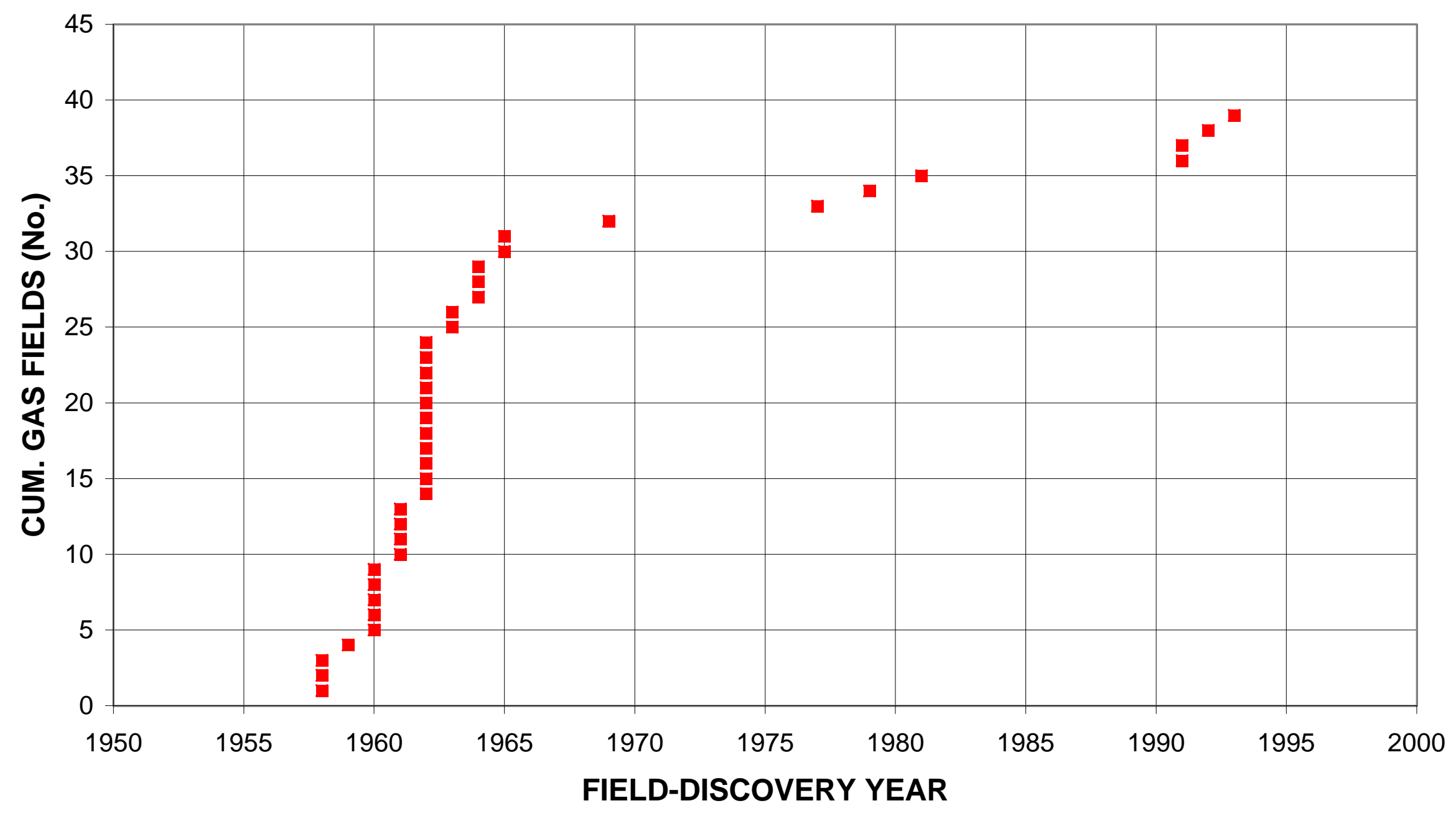


Tanezzuft-IIlizi Structural/Stratigraphic, Assessment Unit 20560101

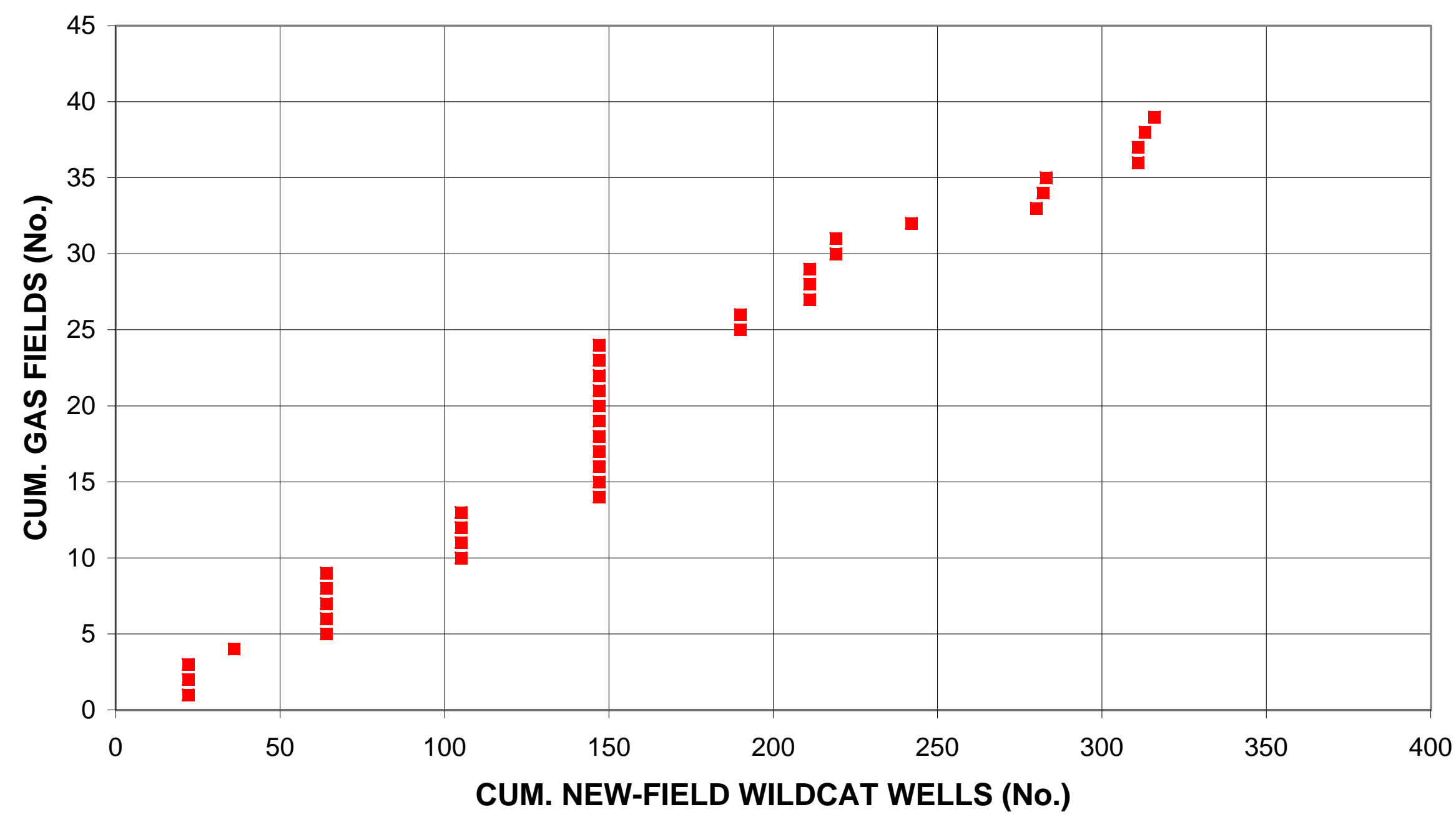


Tanezzuft-Illizi Structural/Stratigraphic, Assessment Unit 20560101

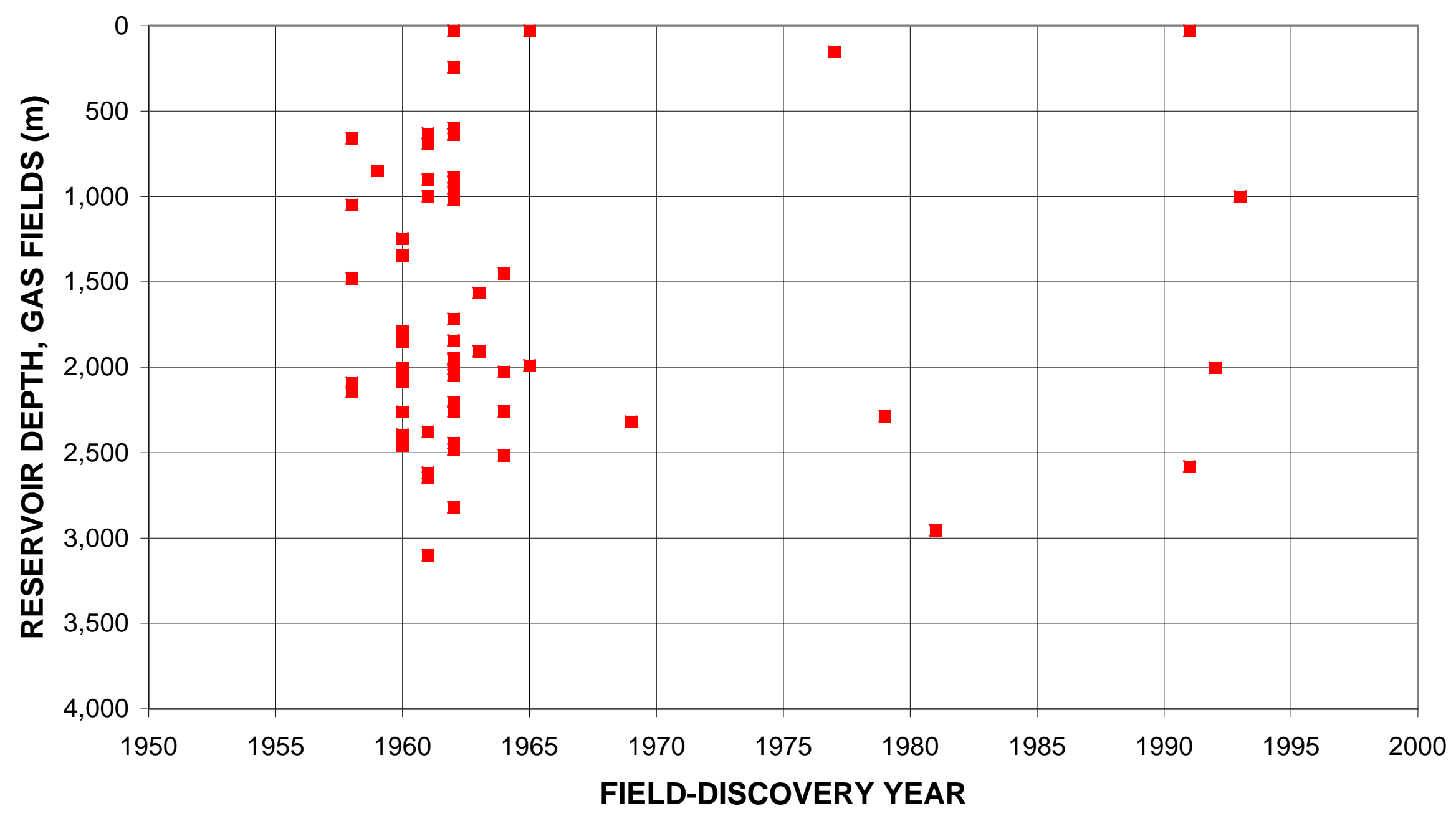


Tanezzuft-IIlizi Structural/Stratigraphic, Assessment Unit 20560101

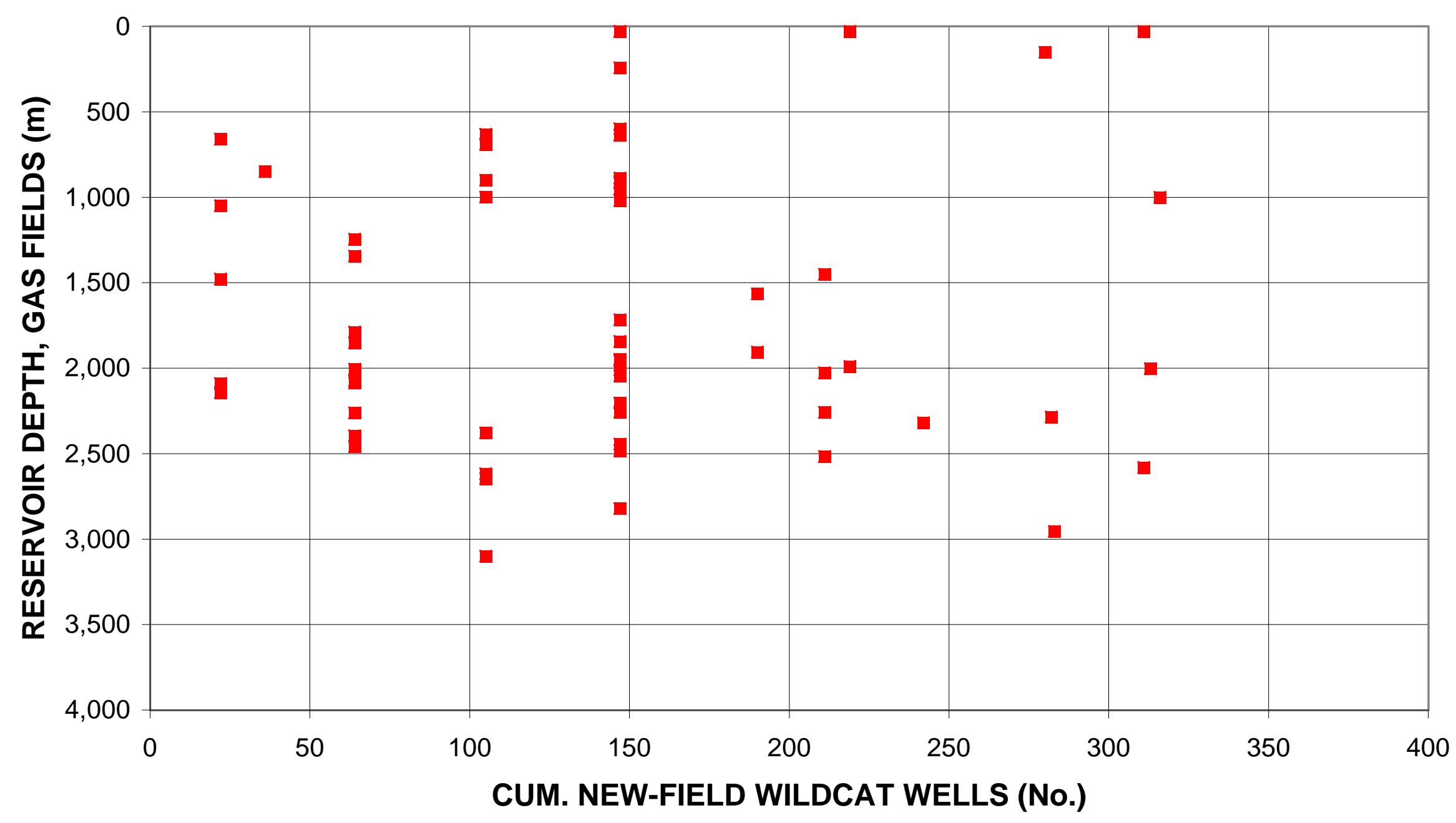


Tanezzuft-IIlizi Structural/Stratigraphic, Assessment Unit 20560101

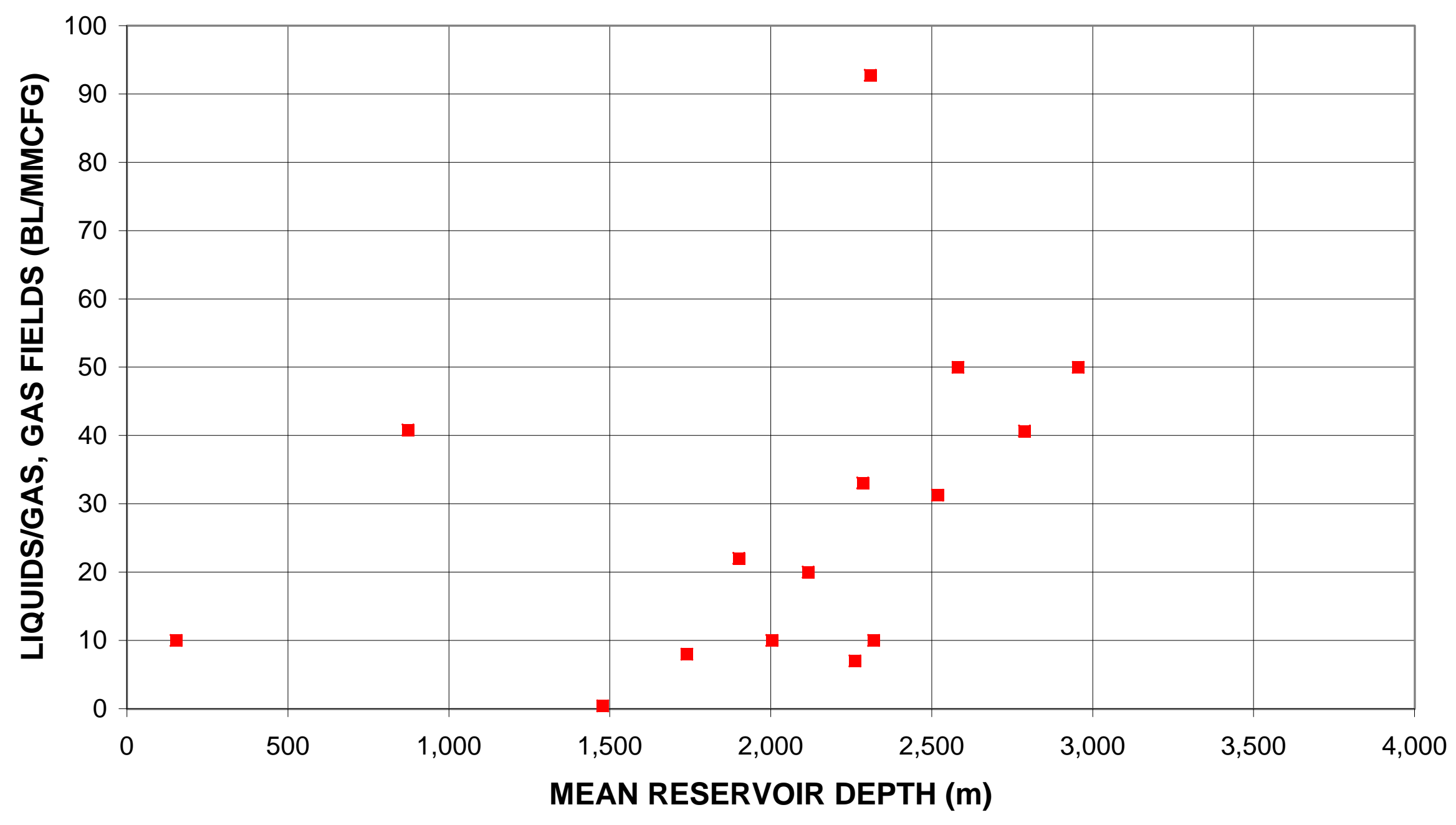

